\title{
Between- and within-group variation in first and second language syntactic priming
}

\author{
Marion Coumel $^{\mathrm{a}}$, Ema Ushioda ${ }^{\mathrm{b}}$, Katherine Messenger ${ }^{\mathrm{a} *}$

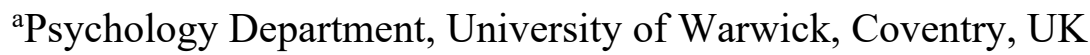 \\ ${ }^{b}$ Department of Applied Linguistics, University of Warwick, Coventry, UK
}

*Corresponding author:

Department of Psychology

University of Warwick

Coventry CV4 7AL, United Kingdom

E-mail: m.coumel@warwick.ac.uk. ORCiD ID: https://orcid.org/0000-0002-6547-1781

The complete datasets and supplementary materials of the study are provided online in a dedicated repository on the Open Science Framework

(https://osf.io/k2tay/?view_only=1849e74a6c4e4c7180667bda6f9ff530).

Number of figures: 13 


\title{
Highlights
}

- L2 and L1 speakers showed lexical boost and persistent syntactic priming effects

- L2 speakers showed stronger and persistent lexical boost effects than L1 speakers

- Syntactic priming was related to individual differences in attention

- Syntactic priming with and without lexical overlap rely on different mechanisms

- Syntactic priming effects vary across different syntactic alternations

\begin{abstract}
We tested the predictions of the error-based implicit language learning model of syntactic priming in second (L2) and first (L1) language speakers. We compared L2 and L1 French speakers' production of fronted/non-fronted temporal phrases and active/passive structures when primed with and without lexical overlap. We also measured the effect of attention and motivation on priming. Our findings are compatible with the general predictions of the model: we observed immediate and long-term priming, and lexical boost effects; individual differences in attention modulated priming strength. Moreover, the results suggest that priming with and without lexical overlap relies on different mechanisms. Nonetheless, some findings contradicted the model's predictions: immediate abstract priming only arose for the fronting alternation; L2 speakers did not show consistently larger priming effects than L1 speakers; patterns of syntactic priming varied highly across syntactic alternations, even within individuals. Overall, the study highlights the importance of comparing priming of different structures within speakers.
\end{abstract}

Keywords: syntactic priming; second language learning; individual differences; attention; motivation 


\section{Introduction}

Speakers' speech production and comprehension is highly malleable throughout their life, be it in their first (L1) or their second (L2) language. For instance, L1 and L2 speakers might produce a previously-dispreferred syntactic structure more frequently if that structure is overrepresented in a given context (Jaeger \& Snider, 2013; Kaan \& Chun, 2017).This type of language malleability, known as syntactic priming, leads speakers and writers to re-use the syntactic form of sentences they have recently been exposed to in their own language production (e.g. Bock, 1986) and makes listeners and readers expect sentences to have the syntactic form of recently-experienced sentences (e.g. Branigan, Pickering \& McLean, 2005). For instance, after exposure to a passive prime sentence (e.g., "the artwork was painted by Nicolas De Staël") it becomes easier for language users to produce and understand a passive target sentence (e.g., "the sculpture was sold by the auctioneer") than if they'd been exposed to an active sentence (e.g., "Nicolas de Staël painted the artwork"). Though priming effects are fairly ubiquitous, in that they occur across different languages, modalities, groups of speakers and language structures, there is considerable variation in the degree to which priming effects are likely to occur, and in the magnitude and duration of such effects (for reviews see Jackson, 2018; Mahowald, James, Futrell \& Gibson, 2016; Pickering \& Ferreira, 2008). As such, the exact nature of the mechanism that underlies priming remains to be fully understood. Examining how priming effects manifest in different structures and different groups of speakers is one way to test the predictions of different explanations of priming, of which there are three prevalent types: implicit error-based models (Chang, Dell \& Bock, 2006; Dell \& Chang, 2014; Jaeger \& Snider, 2013), activation-based models (Pickering \& Branigan, 1998; Pickering \& Ferreira, 2008) and hybrid models which combine features of the former two types (Malhotra, Pickering, Branigan \& Bednar, 2008; Reitter, Keller \& Moore, 2011). In this paper, we focus on the predictions of the implicit error-based models of syntactic priming (Chang et al., 2006), which is a model of language learning as well as priming that can take into account individual variation in priming between speakers. We test whether L2 and L1 speakers primed with two different structural alternations exhibit the immediate and long-term syntactic priming effects, and the within- and between-group variation in such priming, that this model predicts.

\section{Syntactic priming as error-based learning}

Error-based implicit learning models of syntactic priming define syntactic priming as the result of a language learning and processing mechanism. During exposure to language, or 
prime sentences in a syntactic priming study, listeners and readers constantly predict upcoming words (Chang et al., 2006) or sentences (Jaeger \& Snider, 2013) based on their knowledge and experience of the language and compare these predictions to the actual language input they receive. If there is a mismatch between the predicted and the perceived syntax, an error signal is generated which leads to adjustments of the relative weightings of the syntactic representations in the listener's or reader's language system. These modifications increase the weightings of those recently experienced syntactic structures. This makes them more available for subsequent language production, for example, when producing target sentences in a syntactic priming study, and leads to syntactic priming effects.

Error-based learning models are able to account for a wide variety of syntactic priming phenomena, such as the inverse frequency effect (Hartsuiker \& Westenberg, 2000; Kaan \& Chun, 2017), long-term abstract priming effects (Bock \& Griffin, 2000; Hartsuiker \& Kolk, 1998; McDonough \& Mackey, 2008) and short-term lexically-mediated priming effects (lexical boost) (Branigan \& McLean, 2016; Hartsuiker, Bernolet, Schoonbaert, Speybroeck \& Vanderelst, 2008; Mahowald et al., 2016). The error-based implicit learning model of Chang et al. (2006), for instance, suggests that as infrequent structures are less expected, they trigger larger error signals. Therefore, speakers experience more learning and more priming from them than from more frequent structures. Long-term abstract priming effects arise from the progressive adaptation of the weightings in the language system allowing for long-lasting changes in language users' syntactic representations. The boost to priming in the context of overlapping lexical items between prime and target sentences is a short-term effect because it relies on fleeting explicit memory processes. Note that other models of syntactic priming have provided alternative explanations for these phenomena. For instance, activation-based models account for the lexical boost in terms of residual activation of the link between a syntactic structure and the head lexical item (Pickering \& Branigan, 1998) but this model cannot explain long-term priming effects. Hybrid-models offer an explanation of short-term and long-term priming, including lexical boost and inverse frequency effects (Reitter et al., 2011; Malhotra et al., 2008). However, these models have not been linked to language acquisition and syntactic priming in learners.

The implicit error-based model of syntactic priming of Chang et al. (2006) is specifically designed to link priming effects in adult speech to other psycholinguistic processes and language acquisition phenomena (Dell \& Chang, 2014). Though an individual's learning rate diminishes as they acquire their native language (as their 
representations come to accurately reflect the language they are exposed to), learning or adaptation via this mechanism remains possible throughout life. This leads to syntactic priming effects in adult speech, particularly with unexpected structures in L1 contexts, when a speaker's prediction about upcoming words and structure is likely to be erroneous (Hartsuiker \& Westenberg, 2000), but also in L2 speakers who are learning a new language (see Jackson (2018) for a review). The model therefore has the potential to account for L2 learning via syntactic priming (cf. Hartsuiker, Pickering \& Veltkamp, 2004 and Hartsuiker \& Bernolet, 2017 for adaptations of activation-based models to account for L2 priming). Moreover, as in the case of L1 children acquiring their first language, L2 speakers should exhibit larger priming effects than L1 speakers as they should experience larger prediction error due to their less advanced knowledge of the target language. Furthermore, this model is able to account for individual variation in priming effects as priming (learning) is determined by an individual's learning rate, which may be in turn be affected by speaker characteristics such as attention, motivation and proficiency (Chang et al., 2006).

As such, this model generates clear predictions for between- and within-group variation in syntactic priming in L1 and L2 speakers which remain to be tested. We first discuss the predictions for between-group variation in priming effects for L2 versus L1 speakers. We then outline possible factors that might lead to within-group, that is individual, variation in priming.

\section{Comparing syntactic priming in L2 and L1 speakers}

Since Chang et al (2006)'s model is a language learning mechanism relying on the progressive adaptation of syntactic representations in speakers' language system, language users should display not only immediate- but also long-term priming effects. Existing studies support this prediction as the influence of prime sentences on subsequent L1 and L2 language production persists in spite of intervening filler sentences between prime and target sentences (Bock \& Griffin, 2000; Branigan, Pickering \& Cleland, 2000; Hartsuiker \& Kolk, 1998; Shin \& Christianson, 2012), also when comparing production levels of a target structure in a posttest with unrelated or no primes relative to baseline measurements (Jackson \& Ruf, 2017a; Kaschak, Kutta \& Jones, 2011; Kidd, 2012) and even when participants' production of target structures is tested one or more weeks after the syntactic priming manipulation (Branigan \& Messenger, 2016; Kaschak, Kutta \& Schatschneider, 2011; McDonough \& Chaikitmongol, 2010; Savage, Lieven, Theakston \& Tomasello, 2006). 
Given its error-based learning mechanism, Chang et al. (2006)'s model further predicts that syntactic priming effects should be larger in L2 speakers who, overall, should experience larger prediction errors than L1 speakers. Few studies have compared syntactic priming in L1 and L2 speakers tested in the same target language and those that have showed contradictory results. Only three studies found evidence for larger immediate priming in L2 speakers than in L1 speakers (Flett, 2006, experiments 1 and 2; Jackson \& Hopp, 2020), whereas a few others report similar priming effects in both groups of speakers (Abrahams, Hartsuiker, De Fruyt \& Bajo, 2019; Flett, 2006, experiment 3; Ruf, 2011). It has been hypothesized that target structure baseline frequencies (Flett, 2006), L2 speakers' proficiency (Abrahams et al., 2019; Ruf, 2011) or priming strength in L1 speakers (Flett, 2006; Nitschke, Serratrice \& Kidd, 2014 in comprehension priming) could determine whether a group difference emerges. However, an unexplored argument is whether observing such a difference depends on the nature of the syntactic alternation tested. The model predicts that less expected structures should trigger larger error signals and thus lead to larger priming effects: both L1 and L2 speakers exhibit this so-called inverse preference effect (Hartsuiker \& Westenberg, 2000; Kaan \& Chun, 2017). Thus, if priming is related to prediction error when processing a prime structure then differences in the syntactic complexity of syntactic structures as well as their baseline frequencies within the L1 or the L2 could influence the degree of priming in each group by influencing the magnitude of the error signal experienced when processing the prime sentence. Put simply, whether L2 or L1 speakers make prediction errors when processing the primes might vary according to the syntactic structures manipulated. While L2 speakers have overall less experience with the target language and should always experience larger prediction errors than L1 speakers, they should be even more likely to do so when the target structure is more complex and less frequent.

Furthermore, if L2 speakers experience more learning during the priming manipulation because they are more likely to make prediction errors in processing prime structures, then we should also observe more long-term priming in this group than in the L1 speakers. To our knowledge, only one study, which targeted the fronted/non-fronted temporal adverbial phrases alternation ("In the morning, the grandfather drinks hot chocolate" vs. "The grandfather drinks hot chocolate in the morning"), has compared long-term syntactic priming effects in L1 versus L2 speakers (Jackson \& Hopp, 2020). Its results do not support this prediction as L2 speakers exhibited larger immediate but not long-term priming effects than L1 speakers. However, the interaction between prime syntax and group for immediate 
priming was only marginally significant, which may explain why the group difference did not transfer to long-term priming.

The lexical boost to priming has been observed in L1 and L2 speakers (Branigan et al., 2000; Flett, 2006; Jackson \& Ruf, 2017a, 2017b; Kim \& McDonough, 2008; Mahowald et al., 2016; Pickering \& Branigan, 1998; Ruf, 2011). Chang et al (2006)'s model predicts that this lexical boost should be short-lived because priming effects with overlapping lexical items between prime and target sentences rely on fleeting explicit memory processes registered in individuals' short-term memory, not on the error-based implicit learning mechanism. In line with these predictions, lexical boost effects in L1 speakers are frequently observed to be short-lived and do not survive the inclusion of intervening trials between prime and target sentences (Hartsuiker et al., 2008; Mahowald et al., 2016). To our knowledge, whether lexical boost effects are short-lived in L2 speakers has not been extensively investigated so far but one study (Ruf, 2011) suggests that including lexical overlap does not lead to larger long term priming effects (see also Jackson \& Ruf, 2017b and McDonough, 2011). Thus, the mechanism of priming with lexical overlap in L2 speakers remains ambiguous. However, the few studies that compare the immediate effect of lexical overlap in L1 vs. L2 speakers suggest that lexical overlap attenuates between-group variation in priming of fronted locative phrases (Ruf, 2011) and passive sentences (Flett, 2006). This finding is in line with the model's prediction that lexical boost does not rely on the errorbased mechanism but on short-term memory.

Finally, it is worth nothing that the architecture of this model predicts individuallyconsistent priming effects within speakers, irrespective of group. If abstract syntactic priming depends on error-based learning which is itself determined by an individual's learning rate (Chang et al., 2006), the degree of priming an individual exhibits on one structure should nonetheless relate to the degree of priming they show on another structure (Branigan \& Messenger, 2016). Relatedly, if syntactic priming with lexical overlap depends on the capacity of L1 and L2 speakers' short-term memory (Chang et al., 2006), then within individuals the degree of priming with lexical overlap should be consistent across priming structures.

In sum, Chang et al (2006)'s model predicts both immediate and long-term priming in both speaker groups. Without lexical overlap, immediate priming effects should be larger in L2 than in L1 speakers, which should in turn lead to a similar group difference in long-term priming effects. Such between-group variation may also depend on the structural alternation being primed. Priming with lexical overlap should lead to short-lived lexical boost effects in 
both groups of speakers and should also cancel out any between-group variation. Lastly, if syntactic priming effects without overlap depend on individuals' learning rate and priming with overlap on individuals' short-term memory, then the degree of priming in both conditions should be consistent within individuals across target structures. To date, few studies have directly compared L2 and L1 speakers' syntactic priming behaviour across all these dimensions and, the few which have done so, do not lead to clear conclusions regarding these predictions of the error-based model (Chang et al., 2006).

\section{Individual variation in syntactic priming.}

While individual variation in syntactic priming is widely observed within groups of L1 and L2 speakers (Mahowald et al., 2016), the evidence for which factors explain this within-group variation remains limited. Chang et al. (2006) propose that variation in individual speaker characteristics, such as attention, motivation and proficiency could affect individuals' learning rate, a key component of the model determining priming magnitude. The effect of attention on syntactic priming can be examined in both L1 and L2 speakers, but L2 speakers are a particularly well-suited population to assess the effect of motivation and proficiency. Most straightforwardly, proficiency might modulate priming effects because individual differences in proficiency will lead to differences in how likely a participant is to predict an upcoming structure accurately.

Previous syntactic priming research with L1 speakers suggests that both higher levels of attention to syntax and attention to the stimuli and the task could foster deeper processing of the stimuli. This could in turn facilitate mismatch detection between predicted and actual input and thus lead to larger priming effects. Participants who are instructed to specifically pay attention to the syntactic form of the stimuli show larger priming effects than participants asked to focus on their semantic content (Bock, Loebell \& Morey, 1992) while being involved in a task with a goal explicitly shared with an interlocutor leads to larger priming effects (Reitter \& Moore, 2014). Participants who hear primes in a dialogue or being directly addressed to them are more likely to prime than those hearing them in a monologue or as side participants (Branigan, Pickering, McLean \& Cleland, 2007; Schoot, Hagoort \& Segaert, 2019; but see Ivanova, Horton, Swets, Kleinman \& Ferreira, 2020). In these cases, participants may show greater priming because their level of attention to the stimuli and the task may be higher in order for them to be able to achieve understanding and respond to the interlocutor. 
Though the effect of attention on syntactic priming in L2 has never been directly tested, we could expect the same pattern of results in L2 speakers. Furthermore, second language acquisition (SLA) studies show that in implicit language learning contexts, explicit manipulations such as providing participants with instructions about the targeted form (Indrarathne \& Kormos, 2017) or other enhancement techniques (see Benati, 2016 for a review) trigger attention to the form to be learned and foster second language learning (for a review, see Robinson, Mackey, Gass \& Schmidt, 2012). Thus, implicit L2 learning via syntactic priming could be enhanced by attention to syntax and attention to the stimuli and the task. In line with this prediction, L2 speakers provided with explicit instructions about the target form display larger immediate priming effects than those not provided with such instructions (Shin \& Christianson, 2012). A possible explanation is that, in the condition with explicit instructions, participants were more attentive to the syntactic form both of the prime sentences they were exposed to and of the sentences they were producing.

Moreover, some SLA research has shown that noticing the target structure may support acquisition of L2 knowledge (see Kerz, Wiechmann \& Riedel, 2017 for a review) and Schmidt (1990) proposed that linguistic input can only be learned if it is noticed. For instance, awareness of the syntactic patterns in the input, as indicated by subjects' capacity to describe the syntactic rules and structures present in the stimuli, predicts successful learning of Russian inflectional morphology in English native speakers (Brooks \& Kempe, 2013). Schmidt's Noticing Hypothesis (1990) distinguishes between two levels of awareness: noticing only, i.e. consciously registering the use of a specific grammatical form in the linguistic input, which is necessary to learn a target structure, and noticing and understanding, i.e. also having knowledge of the grammatical rules, which is not necessary, but further facilitates learning. Whether noticing the target structure could similarly influence syntactic priming effects remains to be explored. On the one hand, if syntactic priming derives from an L2 and L1 language learning mechanism, these two levels of awareness could enhance priming effects relative to speakers who are not aware of the target structures at all in both groups of speakers. McDonough and Fulga (2015) found that L2 speakers sometimes only exhibited abstract syntactic priming effects if they had detected the target structure. On the other hand, if syntactic priming relies on an implicit language learning mechanism, these two levels of awareness may only increase priming effects in the case of lexical overlap, when more explicit processes are involved. In sum, greater attention to syntax, greater attention to task and stimuli and noticing the target structure could enhance 
syntactic priming effects. These factors could further lead to better explicit memory of the primes which might increase the magnitude of lexical boost effects.

Motivation in second language learning is the factor determining the reason why a speaker chooses to learn a target language as well as how much they will persist in doing so and the amount of effort they will dedicate to it (Dornyei \& Skehan, 2003). In SLA, the nature and the intensity of L2 learning motivation is also considered a key determiner of achievement in L2 learning (Gardner, 1985; Gardner \& Lambert, 1972; Masgoret \& Gardner, 2003; Ushioda \& Dörnyei, 2012). Therefore, one could expect it to similarly affect L2 learning via syntactic priming although, to our knowledge, this relationship has never been tested before. Importantly, while the link between motivation and L2 achievement is usually investigated by using grades and general L2 proficiency measures as indicators of L2 achievement (for exceptions, see Dörnyei \& Kormos, 2000; Kormos \& Dörnyei, 2004; Saito, Dewaele \& Hanzawa, 2017), an examination of the direct relationship between motivation and language learning task performance such as syntactic priming tasks would help in understanding how motivation relates to the acquisition of specific L2 target structures (Ushioda, 2016).

To investigate the multifaceted nature of motivation as a psychological construct, researchers in SLA typically create subdivided categories targeting different aspects of language learning motivation. The following categories have specifically been found to relate to L2 production and L2 achievement, and could therefore influence L2 learning via syntactic priming: intrinsic motivation (Cheng, Klinger, Fox, Doe, Jin \& Wu, 2014; Kang, 2001; Noels, Clément \& Pelletier, 2001; Wen, 1997), extrinsic motivation (Kang, 2001; Wen, 1997), motivational intensity (Cocca \& Cocca, 2019; Gardner, 1985; Noels et al., 2001; Serafini, 2013) and task motivation or attitude towards the task (Dörnyei, 2002; Dörnyei \& Kormos, 2000; Kormos \& Dörnyei, 2004). Intrinsic motivation and extrinsic motivation respectively reflect an inherent desire to learn a language for the affective rewards of engaging with learning activities (e.g. "I enjoy the experience of surpassing myself when practicing French") vs. learning to obtain a reward or avoid a punishment (e.g., "I don't want to fail the French course") (Deci \& Ryan, 1985). Motivational intensity is an indicator of the strength of engagement in language learning activities (e.g. "I am working hard at learning French") (Gardner \& Lambert, 1972). Finally, task motivation can, for instance, be conceptualized as a combination of task enjoyment (e.g. "I found the task interesting") (Eccles, 1993) and reported effort (e.g. "I put a lot of effort in doing the task) (Boekaerts, 2002). 
Individual differences in motivation could also affect syntactic priming by influencing learners' attention and awareness during the task (Crookes \& Schmidt, 1991; Ushioda, 2016). First, the nature of participants' motivation and their language learning goals may determine which aspects of the task they pay attention to. Takahashi (2005) found that participants with strong intrinsic motivation noticed the target linguistic features more. Saito et al. (2017) observed that participants' progress in comprehensibility depended on how strongly they wanted to speak comprehensible English in the future. Similarly, L2 speakers motivated to learn grammar could focus more on this aspect of the task. Second, participants may be more motivated by a task and thus, more attentive to it if they think it is useful to reach their language learning goals (Wigfield \& Eccles, 2000).

In sum, individual variation in three forms of attention (to syntax, to the stimuli and the task and noticing) for L1 and L2 speakers and motivation and proficiency for L2 speakers may modulate speakers' learning rate, which in turn should modulate the degree of syntactic priming between individuals. However, studies so far have only investigated the role of attention in L1 speakers and whether individual differences in motivation affect L2 speakers' priming behaviour has never been examined.

\section{Present study}

The present study tested whether we would observe the between- and within-group variation in L2 and L1 syntactic priming effects predicted by the error-based implicit learning model (Chang et al., 2006). To do this we compared immediate and long-term priming effects with and without lexical overlap for two different structural alternations in L2 and L1 speakers, and we assessed individual differences in proficiency, attention and motivation.

We predicted that overall, immediate abstract syntactic priming would be stronger in L2 than in L1 speakers and that this should lead to greater long-term priming in L2 than in L1 speakers. We further predicted that if priming with lexical overlap relies on explicit memory processes, lexical overlap should boost immediate priming but this lexical boost effect should not persist in long-term priming in either group of speakers. It should also cancel out between-group variation in immediate priming.

To address the issue of whether group differences depend on the frequency and complexity of target structures, we compared syntactic priming on two syntactic structure alternations: the fronted/non-fronted temporal adverbial phrases (TP) ("In summer, the cowboy wears a hat" vs. "The cowboy wears a hat in summer") and active/passive transitive syntactic alternations ("The pirate is following the sailor" vs. "The sailor is being followed by 
the pirate"). Previous studies targeted a variety of syntactic structures (active/passive transitive structures; prepositional/double object ditransitive structures; fronted/non-fronted temporal or locative adverbial phrases) (Abrahams et al., 2019; Flett, 2006; Jackson \& Hopp, 2020; Nitschke et al., 2014; Ruf, 2011), but none of them compared two different syntactic alternations in the same target language within the same groups of L1 and L2 speakers. We expected the active/passive alternation to elicit a larger difference in immediate priming between L2 and L1 speakers than the fronted/non-fronted TP alternation for two reasons. First, there is a larger difference in terms of baseline frequency of active versus passive sentences than of fronted versus non-fronted TPs (see pre-test measurements in Jackson \& Ruf, 2017a). Second, the active/passive alternation can be considered more syntactically complex than the fronted/non-fronted TP alternation. While both alternations involve a change at the levels of information structure and constituent structure between their two structures, the active/passive alternation additionally entails a change in grammatical role attribution. We expected L2 speakers to be more affected by these two factors than L1 speakers due to their overall lower level of experience with the target language. Therefore, we predicted that L2 speakers would be more likely to make prediction errors on the active/passive than on the fronted/non-fronted TP alternation, and that, as a consequence, a between-group difference in immediate priming would be more likely to emerge on the former than on the latter alternation. If this is the case, we predicted that we should also be more likely to observe a group difference in long-term priming on the active/passive than on the fronted/non-fronted TP alternation.

In addition to examining whether the type of syntactic alternation being primed influenced the pattern of between- and within-group variation, we assessed whether there was a within-individuals relationship in priming across structures. By testing the same participants on both structures, we can examine whether the degree of priming an individual shows with one structure is related to the degree of priming they show with the other structure.

We assessed L2 and L1 speakers' individual differences in attention to syntax, attention to the stimuli and the task and awareness of the target syntactic form as well as L2 speakers' individual differences in proficiency and motivation. We predicted that increased attentional and motivational levels would increase participants' learning rate and thus lead to larger immediate and long-term priming effects. Similarly, we predicted that if the participants' aim was to learn French grammar and if they thought the task was helping them progress in French, they would be more sensitive to priming. We expected individual 
differences to modulate priming effects in both syntactic alternations but we predicted that they would not influence the lexical boost to priming as the lexical boost does not rely on the error-based mechanism and should thus remain unaffected by learning rate.

We tested these predictions in two three-phase experiments - one experiment targeted the fronted/non-fronted alternation, the other targeted the active/passive alternation. French L1 speakers and L2 French speakers, who were L1 speakers of English studying French at a UK university, described pictures to the experimenter as part of a search task (Branigan et al., 2000). In the first phase of each experiment, they described pictures without hearing syntactic primes; this baseline phase assessed each group's preference for each structure. The middle phase was an immediate priming phase: participants described target pictures immediately after hearing prime descriptions from the experimenter. This phase measured the immediate effect of priming on L2 and L1 speakers' production of target structures. The last phase was a post-test in which once again participants described pictures without hearing primes; this post-test phase assessed the persistence of the priming effects established in the middle phase. We measured the frequency with which participants continued to produce dispreferred structures after the priming phrase. All participants completed all phases of each experiment (i.e. for both syntactic structures); half the participants were exposed to primes with lexical overlap and half were exposed to primes without lexical overlap. Since the fronted items included many active transitive sentences, the order of the experiments was fixed with transitive priming, which sought to prime passive transitive sentences, occurring before fronted priming for all participants. Participants' individual differences in attention and motivation were measured with self-report questionnaires.

We first examine the strength of immediate and long-term priming in each group and whether this is modulated by lexical overlap. We then explore the contribution of individual differences in proficiency, attention and motivation to these priming effects. Lastly, we examine whether there was a relationship between individual's magnitude of priming within each experiment.

\section{Experiment 1- Fronted/ non-fronted TP alternation}

First, we examined syntactic priming for fronted/non-fronted temporal adverbial phrases, with and without lexical overlap between prime and targets in native speakers of French and English-speaking learners of French. The pre-registration of the study, its scoring system, and data are available on OSF (see Supplementary material). 


\section{Methodology}

Participants

104 English native speakers learning French as a second language (L2 speakers) and 100 native speakers of French (L1 speakers) participated in Experiment 1 (and 2). Participants completed a language background questionnaire (adapted from the LEAP-Q questionnaire; Marian, Blumenfeld \& Kaushanskaya, 2007) to establish their status as native speakers of French or English and learners of French. They were all university students and all received money as compensation for their participation. The study was approved by the Humanities and Social Sciences Research Ethics Committee at the University of Warwick. Informed consent was obtained prior to the test session.

We excluded 3 participants who reported being native speakers of both languages and 10 who were not native speakers of French or English. One participant was excluded due to experimenter error. As a result, the analyses included 95 L2 speakers (76 female); 46 in the no lexical overlap condition and 49 in the lexical overlap condition, and 95 L1 speakers (76 female); 45 in the no lexical overlap condition and 50 in the lexical overlap condition. Participants were aged 18 to 28 years, $(M=19.86)$.

\section{Design}

We used a 2 x 2 design with two between-participants variables: Lexical Overlap condition (overlap vs. no overlap) and Speaker Group (L1 vs. L2 speaker). The experiment had three test phases, which all participants experienced: baseline, priming and post-test. Prime Syntax (fronted vs non-fronted) for immediate priming and Section (pre-test vs. posttest) for long-term priming were within-subject variables.

\section{Materials}

Prime/target cards

We created 36 target items consisting of a French temporal adverbial phrase (e.g., en été (in summer)) and a transitive event (e.g., le cowboy porte un chapeau (the cowboy wears a hat)). We used 3 different types of adverbial phrases (à (at), en/au (in), chaque (every)) twelve times each with temporal references to times, days and seasons (e.g. , à midi (at midday), à 14 heures (at 2pm), en été (in summer), au printemps (in spring), chaque lundi (every Monday), chaque jeudi, (every Thursday)). Each type of temporal adverbial phrase was used eight times in the priming phase (24 items), and twice in both the pre-test (6 items) and the post-test (6 items). Temporal adverbial phrases were paired with a transitive event. 
We used six verbs (écouter (listen), rendre (give back), servir (serve), porter (wear), acheter (buy), faire (go/do)) six times each with different combinations of animate agent characters and animate or inanimate patients. Each verb appeared once in the pre-test (6 items), four times in the priming phase (24 items) and once in the post-test (6 items).

For the priming phase, we created a prime item with and without lexical overlap (of the adverbial phrase) for each target item. The same temporal adverbial phrases as used in the target sentences were combined with different transitive events to create 24 prime sentences. In the no lexical overlap condition, the prime had a different temporal adverbial phrase to the target item (as well as a different transitive event); in the lexical overlap condition, the same temporal adverbial phrase (but a different transitive event) was used in the prime as in the target item. Prime pictures had an associated fronted and non-fronted description, see Figure 1 and Appendix A. We created four lists, two with lexical overlap and two without and so that one version of each experimental prime item (fronted or non-fronted) appeared in each list. Participants were randomly assigned to one of the four lists.

In the priming phase, prime-target pairs were separated by two filler pictures (resulting in a Prime-Target-Filler-Filler sequence) and in the pre-/post-test sections target pictures were separated by three filler pictures. We created 84 filler pictures in total using intransitive verbs (depicted with two characters, such "the monks are crying), ditransitive verbs (depicted with two characters and an object, such as "the monk is selling the artist a cup") and sentences containing possessives (depicted with the possessor appearing in one corner of the picture, such "the ballerina eats the cake of her grandmother"). 36 appeared in the target set ( 6 in the pre-test, 24 in the priming phase and 6 in the post-test) and 48 appeared in the prime set (12 in the pre-test, 24 in the priming phase and 12 in the post-test).

In total, there were 72 pictures (36 targets and 36 fillers) in the participant's description set and 72 pictures ( 24 primes and 48 fillers) in the experimenter's description set (see Appendix A). Items were depicted on individual cards $(10 \mathrm{~cm} \times 10 \mathrm{~cm})$, which included word labels (nouns and verbs) to prevent problems of vocabulary retrieval. The temporal adverbial phrase was represented in a corner of the card (see Figure 1). The position of the pictures depicting the temporal adverbial phrases was counterbalanced to appear an equal number of times on the right and left side of the card.

\section{[Insert Figure 1 about here]}

Attention and awareness questionnaire 
The attention and awareness questionnaire was divided into two sections and assessed three aspects of attention: attention to syntax, attention to the stimuli and the task (first section), and awareness of the target structures (second section). In the first section, participants were asked to provide a rating on a scale from 1 (minimum score) to 7 (maximum score) of the extent to which they paid attention to and were interested in 1) what the experimenter was saying, 2) the picture description task in general, 3) the meaning, 4) the vocabulary, 5) the pronunciation, 6) the syntactic structures of the sentences they heard and produced.

In the second section, participants were asked to answer three questions designed to measure their capacity to describe the syntactic rules and structures present in the stimuli (Brooks \& Kempe, 2013): (1) “explain, in your impression, what was the experiment about?”, (2) "did you notice any grammatical rules of French underlying the sentences you heard in the picture description task?", and (3) "can you name and/or describe what the rules were that were illustrated by the sentences you saw during the picture description task?". Participants' responses to these questions were scored so as to distinguish noticing from noticing and understanding (Schmidt, 1990; see scoring section for more details).

\section{Motivation questionnaire}

Previous research has not investigated the relationship between motivation and syntactic priming in L2 speakers, or indeed the relationship between motivation and language-learning tasks more generally (Ushioda, 2016). As such, we created a motivation questionnaire, based on motivational factors that have been found to relate to L2 achievement or which we hypothesized could influence syntactic priming, to explore which motivational aspects might predict priming.

Participants read statements and rated how strongly they agreed with them on a scale of 1 (strongly disagree) to 7 (strongly agree). The questionnaire items assessed externally regulated motivation ( 9 items), intrinsic motivation ( 8 items), task motivation (6 items), motivational intensity ( 8 items), how important learning French was important for the participants ( 2 items), participant's metacognition about the task and the language (6 items) and participant's language learning goals (9 items) among which 5 items specifically assessed whether participants were interested in improving their grammatical knowledge of French (grammar learning goal) (see Appendix C for a complete list). Where possible we used items from existing, pre-tested questionnaires (Boekaerts, 2002; Deci \& Ryan, 1985; Dörnyei, 2010; Gardner, 1985; Noels, Pelletier, Clément \& Vallerand, 2000; Saito et al., 
2017; Serafini, 2013; Wiegfield, 1994) but some items were necessarily created by us. The presentation of items was randomized across categories and participants.

\section{Proficiency questionnaire}

We used self-reported proficiency, which has been found to correlate with direct measures of proficiency (Lemhofer \& Broersma, 2012; Favier, Wright, Meyer \& Huettig, 2019), as a control measure. Participants rated their overall proficiency, their speaking proficiency, their understanding proficiency and their reading proficiency on a scale from 0 (minimum score) to 10 (maximum score).

\section{Procedure}

We used a scripted comprehension-to-production priming task in which participants performed a picture description and searching task with the experimenter (Branigan et al., 2000). The participant and the experimenter, who was a French native speaker, sat at opposite ends of a table with two sets of picture cards in front of them: the searching set and the description set. A screen was placed on the table so that they could not see each other's description and searching sets. The searching set was arranged as an array of cards facing upwards, organised in alphabetical order by verb to facilitate finding. The description set contained the cards to be described on each turn. The experimenter's descriptions were written on her cards to ensure the correct prime sentences were produced.

The participant and experimenter took turns to describe a card to their partner and to search for the card corresponding to the description of their partner. The experimenter started by reading the description of her first card taken from the top of her description set which was the first prime. The participant searched for the card matching that description in the searching set and put it aside. On the following turn, the participant described the first card taken from their description set, thereby producing the first target sentence. The experimenter searched for the corresponding card in her searching set and put it aside. The experiment continued this way until all cards from both description sets had been described. The task was audio-recorded with a Zoom H1 recorder.

Participants completed Experiment 1 and Experiment 2 within a single session. To create a break between the two priming experiments, they completed the language background and proficiency questionnaire on paper between the two priming tasks. Participants completed the attention and awareness (L1 and L2 speakers) and the motivation questionnaire (L2 speakers only) on a laptop at the end of the experiments. 


\section{Scoring}

The scoring system and analysis plan of the two experiments were pre-registered on OSF before we analysed the data (see Supplementary material). We subsequently modified the original analysis plan to account for convergence issues, issues of highly intercorrelated items and to simplify the analysis (see "Summary of amendments" file on the OSF repository). We report the final analysis here. The outcomes of all the models we ran can be found on OSF.

\section{Target sentences}

We coded responses in which the temporal adverbial phrase appeared in sentenceinitial position as fronted sentences, and we coded responses in which the temporal adverbial phrase was produced in sentence-final position as non-fronted sentences. We excluded sentences in which the temporal adverbial phrase was not produced and unfinished sentences (where participants stopped at any point before the object was produced). We did not code whether an active or a passive structure was employed to describe the transitive action and ignored morphological errors. L2 speakers produced 3348 fronted and non-fronted target sentences and 69 responses scored as other, L1 speakers produced 3354 fronted and nonfronted target sentences and 58 responses scored as other; see Table 1 for a breakdown by conditions and experiment phase.

\section{[Insert Table 1 about here]}

\section{Attention and awareness questionnaire}

Each participant received three attention scores. We averaged participants' scores on question 1 and 2 of the questionnaire to create a measure of participants' attention to the stimuli and the task (Branigan et al., 2007; Ivanova et al., 2020; Schoot et al., 2019). L2 French speakers showed a mean score of 5.58 (range 3.5-7) and L1 speakers showed a mean score of 5.19 (range 1.5-7) for attention to the task; see Table 2 for a breakdown by condition. We used their rating for question 6 to assess their attention to syntax specifically (Bock et al., 1992). L2 French speakers showed a mean score of 5.16 (range 1-7) and L1 speakers showed a mean score of 5.19 (range 1-7); see Table 2 for a breakdown by condition.

To assess participants' awareness of the target structures, we examined the second section of the questionnaire. Participants received a score of 2 (henceforth "Noticing 2") if they had understood and noticed the fronting-non-fronting alternation (Schmidt, 1990), that 
is, they were able to name, describe or give examples of the fronted vs. non-fronted sentences. They received a score of 1 (henceforth "Noticing 1") if they only mentioned that there were temporal adverbial phrases or "time indication" in the stimuli but did not describe the structural alternation. They received a score of 0 if they did not refer to fronted vs. nonfronted alternation in any way. $27.4 \%$ of L2 French speakers scored 2, 15.8\% scored 1 and $56.8 \%$ scored 0 , whereas $30.5 \%$ of L1 French speakers scored 2, 7.4\% scored 1 and $62.1 \%$ scored 0 ; see Table 3 for a breakdown by condition.

\section{Motivation questionnaire}

While we originally planned to use the 7 distinct categories of motivation in the analyses (see original pre-registration document), preliminary inspection of the data revealed that the scores for items coming from distinct motivation categories were highly inter-related. To reduce the number of motivation dimensions, we conducted a Principal Component Analysis with the L2 speakers' scores on 44 Likert-scale survey items, which identified correlated responses across the different categories of motivation (see amendment of the preregistration). From the language learning goal category, we only included the items related to the desire to learn French grammar as these were judged the most likely to relate to syntactic priming effects (grammar learning goal). To ensure we would have enough data points for the PCA analysis, we ran it with the scores of the participants included in the final analysis for Experiment $1(\mathrm{~N}=95)$. Some of these participants were excluded from the analysis of Experiment 2 (see below). The PCA analysis revealed that two principal components (PCs) accounted for the most variance in the data, with PC1 explaining $15.65 \%$ of variance and PC2 explaining 10.69\%. The Cronbach alpha for PC1 was .87 and .59 for PC2. Subsequent dimensions did not differ enough from each other (Figure 2).

\section{[Insert Figure 2 about here]}

To select the items loading on each of these two PCs and avoid cross-loadings, we followed Takahashi's (2005) cut-off criterion of .45 correlation level. The final two motivation scores we included in the analysis corresponded to these two PCS and were calculated by averaging an individual's scores of all the items loading on each PC respectively. While grouping motivation categories into PCs would not allow us to investigate the effect of each motivation aspect as originally planned, we interpreted $\mathrm{PC} 1$ as representing motivation to learn French in general and PC2 as representing task-specific motivation. PC1 included all items measuring 
how important it was for participants to learn French ( 2 items), 7 items came from the original intrinsic motivation category (out of 8 items), 3 items from the grammar learning goal category (out of 5 items), 6 items from the motivational intensity category (out of 8 items) and one item from the external motivation category (out of 9 items) (see Appendix D). PC2 included 4 items from the metacognition category (out of 6 items), 4 items from the task motivation category (out of 6 items) and one item from the external motivation category (negatively correlated) (see Appendix D). L2 speakers had an average rating of 5.36 (range 2.53-6.65) for French motivation and 5.15 (range 3.44-6.22) for task-specific motivation; see Table 2 for a breakdown by condition.

\section{Proficiency questionnaire}

We computed the average of the four proficiency scores participants reported on the self-report scales for overall proficiency, speaking proficiency, understanding proficiency and reading proficiency (as in Bernolet, Hartsuiker \& Pickering, 2013). Overall, L2 speakers had an average rating of 6.31 (range 1.5-9); see Table 2 for a breakdown by condition.

\section{[Insert Table 2 about here] \\ [Insert Table 3 about here]}

\section{Analysis and results}

We conducted two sets of analyses. The first analysis focused on the comparison of priming effects between L1 and L2 speakers with and without lexical overlap over two different time courses: immediate priming and long-term priming.

In the second analysis, we explored the effects of individual differences on each type of priming. We first examined whether proficiency related to immediate and long-term syntactic priming. Where it was a significant predictor, it was included as a covariable in all following models for the priming type in question. We then looked at the effect of individual differences in attention (attention to syntax, attention to stimuli and task, noticing) and motivation (French learning motivation and task-specific motivation) on each type of syntactic priming in the two groups of speakers. We tested the effect of each attention and motivation score separately as we expected each score to specifically contribute to syntactic priming.

As the response frequencies presented in Table 1 showed that speakers of both groups were more likely to produce non-fronted than fronted TPs in the pre-test, we analysed the effect of priming on fronted TP responses. Our dependent variable was binary, so we 
analysed the data with Generalized Logistic Mixed Models (GLMM) (Baayen, Davidson \& Bates, 2008; Jaeger, 2008) using the lme4 package (Version 1.1.21) in R, version 1.2.5042. The dependent variable was coded as $0=$ non-fronted TP and $1=$ fronted TP. The factorial predictors Prime Syntax (fronted vs. non-fronted TP), Section (pre-test vs. post-test), Lexical Overlap (with vs. without), Side (picture representing the adverbial phrase located on the left vs. on the right side of the target picture) and Speaker Group (L2 vs. L1 speakers) were sum contrast coded to have a mean of 0 and a range of 1 prior to analysis. We included Side as an additional predictor as we anticipated that participants could have been more likely to produce fronted sentences if the picture representing the temporal adverbial phrase appeared on the left corner of the card (i.e. if they adopted a strategy of 'reading' across the card; see Figure 1) (Jackson \& Hopp, 2020).

\section{L1 vs. L2 immediate and long-term priming with and without lexical overlap}

For all analyses, we started with a full model including main effects and interactions as well as maximal by-subject and by-item random effect structure justified by our experimental design (Barr, Levy, Scheepers, \& Tily, 2013). To compare immediate priming in L1 vs. L2 speakers with and without lexical overlap, we built a full model including as fixed effects Prime Syntax, Lexical Overlap, Speaker Group, Side and the interaction between all four factors. The model also included random intercepts for participants and items and by-subject random slopes for Prime Syntax and by-item random slopes for Prime Syntax, Lexical Overlap, Speaker Group and their interactions. To analyse long-term priming with and without lexical overlap in L1 vs. L2 speakers, we built a model which included as fixed effects Section, Lexical Overlap, Speaker Group, Side and the interaction between these four factors. We included random intercepts for subjects and items as well as by-subject random slopes for Section and by-item random slopes for Speaker Group, Lexical Overlap and their interaction. Then, we performed a step-wise "best-path" reduction procedure, removing interactions before main effects, to locate the simplest model (best model) that, as shown by ANOVA comparisons, did not differ significantly from the full (converging) model in terms of variance explained but did differ significantly from a model without interactions between the predictors and from a null model which only included the intercept term as a predictor. In the following sections, we report the results of the best models, except where, as stated, these failed to converge or did not provide a better fit than the model without interactions or the null model. When running further models to explore each significant 
interaction, we applied Bonferroni corrections with a corrected alpha level of 0.025 . All pvalues for individual predictors were obtained from the model summary output.

\section{Immediate priming}

Figure 3 shows the mean probability of fronted responses by Prime Syntax, Lexical Overlap and Speaker Group condition. The best model included Prime Syntax, Speaker Group, Lexical Overlap and Side as well as the interaction between them as fixed effects, bysubject random slopes for Prime Syntax and by-item random slopes for Lexical Overlap. This included a significant main effect of Prime Syntax, whereby participants produced more fronted targets after fronted primes $(\mathrm{M}=0.62, \mathrm{SD}=0.49)$ than after non-fronted primes $(\mathrm{M}$ $=0.35, \mathrm{SD}=0.48$ ). There was a significant main effect of Side as participants were more likely to produce fronted sentences when the image representing the temporal adverbial phrases was on the left $(\mathrm{M}=0.52, \mathrm{SD}=0.5)$ than when it was on the right $(\mathrm{M}=0.45, \mathrm{SD}=$ 0.5), however, there was no interaction between Side and Prime syntax. There was no main effect of Lexical Overlap and no main effect of Speaker Group. We found a significant twoway interaction between Prime Syntax and Lexical Overlap: fronted responses were $40 \%$ more likely following fronted primes than non-fronted primes with lexical overlap whereas they were only $13.6 \%$ more likely following fronted primes than non-fronted primes without lexical overlap. There was a significant two-way interaction between Speaker Group and Prime Syntax: the L2 speakers were 32.5\% more likely to produce fronted descriptions following fronted primes than non-fronted primes, whereas L1 speakers were $22.3 \%$ more likely to prime. We also found a significant two-way interaction between Speaker Group and Side: L1 speakers were 9.3\% more likely to produce fronted sentences when the picture was presented on the left, whereas L2 speakers were only $4.5 \%$ more likely to produce fronted sentences when the picture was presented on the left. These effects are qualified by a significant three-way interaction between Prime Syntax, Speaker Group and Lexical Overlap condition (see Table 4 for details) suggesting that the effects of lexical overlap on priming differed by speaker group. We explored these effects for each group separately.

The model for L2 speakers revealed a significant main effect of Prime Syntax, $\beta=$ $1.98(S E=0.17), z=11.82, p<.001$ such that L2 speakers produced more fronted sentences after fronted sentences $(\mathrm{M}=0.63, \mathrm{SD}=0.48)$ than after non-fronted sentences $(\mathrm{M}=0.30$, $\mathrm{SD}=0.46$ ). Additionally, there was a significant interaction between Prime Syntax and Lexical Overlap, $\beta=1.98(S E=0.32), z=6.13, p<.001$, indicating a 35\% significant lexical 
boost: participants were more likely to produce a fronted sentence after a fronted sentence than after a non-fronted sentence when it contained the same fronted adverbial (49\% priming) than when it contained a different fronted adverbial (14\% priming). Simple main effects analyses confirmed that there was a significant main effect of Prime Syntax in the overlap condition, $\beta=2.96(S E=0.29), z=10.06 p<.001$, and in the condition without lexical overlap, $\beta=0.96(S E=0.16), z=6.04, p<.001$, such that L2 speakers were more likely to produce fronted sentences after fronted sentences than after non-fronted sentences in both conditions. In the condition without overlap, there was also a significant main effect of Side, $\beta=-0.35(S E=0.15), z=-2.29 p<.05$, as L2 speakers were more likely to produce fronted sentences when the image representing the temporal adverbial phrase was on the left $(\mathrm{M}=$ $0.50, \mathrm{SD}=0.5)$ than when it was on the right $(\mathrm{M}=0.44, \mathrm{SD}=0.5)$.

The model for L1 speakers revealed a significant main effect of Prime Syntax, $\beta=$ $1.51(S E=0.16), z=9.23, p<.001$, such that L1 speakers produced more fronted sentences after fronted sentences $(\mathrm{M}=0.62, \mathrm{SD}=0.49)$ than after non-fronted sentences $(\mathrm{M}=0.39$, $\mathrm{SD}=0.49)$ and a significant main effect of Side, $\beta=-0.67(S E=0.18), z=-3.6, p<.001$, as participants were more likely to produce fronted sentences when the image representing the temporal adverbial phrase was on the left $(\mathrm{M}=0.55, \mathrm{SD}=0.5)$ than when it was on the right $(\mathrm{M}=0.46, \mathrm{SD}=0.5)$. Additionally, there was a significant interaction between Prime Syntax and Lexical Overlap, $\beta=1.14(S E=0.32), z=3.55, p<.001$, indicating an $18 \%$ lexical boost participants were more likely to produce a fronted sentence after fronted sentence than after a non-fronted sentence when it contained the same fronted adverbial (31\% priming) than when it contained a different (13\% priming) fronted adverbial. Simple main effects analyses confirmed that there was a significant effect of Prime Syntax in the condition with overlap, $\beta$ $=2.21(S E=0.31), z=7.08, p<.001$, and in the condition without overlap, $\beta=0.87$ (SE $=$ $0.16), z=5.41, p<.001$, such that L1 speakers produced more fronted sentences after fronted sentences than after non-fronted sentences in both conditions. In the condition without overlap, there was also a significant main effect of Side, $\beta=-0.96(S E=0.26), z=-3.68$, $p<.001$, as L1 speakers were more likely to produce fronted sentences when the image representing the temporal adverbial phrase was on the left $(\mathrm{M}=0.62, \mathrm{SD}=0.5)$ than when it was on the right $(\mathrm{M}=0.47, \mathrm{SD}=0.5)^{1}$.

\footnotetext{
${ }^{1}$ We also split the data by Lexical Overlap to analyse the effect of Speaker Group. It showed that priming magnitude was larger in L2 than L1 speakers only in the condition with lexical overlap. We uploaded the outcome of this model on OSF (see Supplementary material).
} 
To summarize, in both groups of speakers there was immediate priming both with and without lexical overlap and there was also a lexical boost to priming in both groups, though this was greater in L2 speakers (35\%) than in L1 speakers (18\%). Side of presentation of the temporal adverbial phrase's picture only significantly affected target sentence production in the condition without lexical overlap for both groups, and this effect appeared larger for L1 speakers (14.6\%) than for L2 speakers (6.1\%), but it did not interact with priming.

\section{[Insert Figure 3 about here] \\ [Insert Table 4 about here]}

\section{Long-term priming}

For long-term priming, the reduced model, that did not significantly differ from the full converging model ( $p=.11)$ but was a better fit than the null model $(p<.05)$, did not include random slopes nor interactions between fixed effects (Table 5). This model showed that there was a significant main effect of Section such that participants produced more fronted sentences in the post- $(\mathrm{M}=.49, \mathrm{SD}=.50)$ than in the pre-test $(\mathrm{M}=.29 \mathrm{SD}=.46)$. The main effect of Section shows that there was long-term priming across speaker groups and overlap conditions. Since including interactions between fixed effects in the model did not improve its fit, we can conclude that there were no significant interactions between Section, Lexical Overlap, Speaker Group and Side (see Figure 4).

\section{[Insert Figure 4 about here] \\ [Insert Table 5 about here]}

\section{Effects of individual differences}

To examine the effect of individual differences in attention (L1 and L2 speakers) and motivation (L2 speakers) on immediate and long-term priming, we ran separate models for each individual difference measure, adding each measure to the final (best) model for immediate priming obtained in the first part of the analysis. The factorial predictors Prime Syntax, Section, Lexical Overlap and Speaker Group were sum contrast coded to have a mean of 0 and a range of 1 prior to analysis. All continuous predictors (attention to syntax, attention to task and stimuli, French learning motivation and task-specific motivation) were centered except proficiency, which had a scale starting at a meaningful 0 . Noticing was defined as a categorical factor with three levels where $0=$ not noticing the target structure at all, $1=$ noticing it (Noticing 1 ) and $2=$ noticing it and understanding it (Noticing 2). This factor 
was also sum contrast coded to have a mean of 0 and a range of 1 and we used multiple contrasts to compare not noticing $(-0.66)$ to Noticing $1(0.33)$ and Noticing $2(0.33)$ combined, and to compare Noticing $1(-0.5)$ to Noticing $2(0.5)$.

We compared each converging model which included the targeted individual differences' score to the same model without the score, called the "simplest model" from now on (Weatherholtz, Campbell-Kibler \& Jaeger, 2014). In the following sections, we report the results of the converging models unless they did not provide a better fit than the simplest model. All p-values for individual predictors were obtained from the model summary output.

We first examined whether proficiency related to syntactic priming in L2 speakers to decide whether it should be included as a covariable in the models for each priming type. To check whether proficiency related to immediate syntactic priming in L2 speakers, we added proficiency and its interactions with each fixed effect to the final model for L2 speakers' immediate priming. The converging model showed that proficiency did not relate to immediate priming in this experiment, thus, we did not include it in any of the following models. We also analysed the effect of proficiency on long-term priming in L2 speakers. To do so, we used the final model of the first part of the analysis, removed Speaker Group as a fixed effect and added the two-ways interactions between Section and Proficiency, Lexical Overlap and Proficiency and Side and Proficiency as fixed effects. The model showed a main effect of Proficiency approaching significance $(p=.05)$ and a significant interaction between Section and Proficiency, $\beta=-0.25(S E=0.10), z=-2.51, p<.05$, such that L2 speakers were less likely to show an increase in production of fronted sentences in the post- relative to the pre-test as their proficiency increased. We thus included proficiency as an additional predictor in the models investigating the effect of individual differences in attention and motivation on L2 speakers' long-term priming and we tested the effects of speaker attention on long-term priming in separate models for L2 and L1 speakers.

\section{Attention in the L1 and L2 speakers}

\section{Immediate priming}

The converging models for attention to syntax, attention to stimuli and task and noticing did not significantly differ from the simplest model $(p=.20, p=.24$ and $p=.69$ respectively). Therefore, we found that individual differences in attention did not relate to immediate priming of the fronting alternation. 


\section{Long-term priming}

For L2 speakers, the converging model for attention to syntax did not significantly differ from the simplest model $(p=.15)$ but the converging model for attention to stimuli and task was a better fit than the simplest model $(p=.01)$. It showed that there was a significant main effect of Section, $\beta=5.56(S E=1.25), z=4.46, p<.001$ and a significant interaction between Section and the attention score, $\beta=-.69(S E=0.21), z=-3.3, p<.001$. As participants were more attentive to the task and stimuli, they were less likely to show an increase in proportion of fronted sentences produced in the post-relative to the pre-test (Figure 5a). The converging model for noticing that was a better fit than the simplest model $(p=.002)$ showed that there was a significant interaction between Section and the comparison of Noticing 1 vs. Noticing $2, \beta=2.54(S E=0.62), z=4.11 p<.001$. This indicated that participants who noticed and understood the target structure showed a smaller increase in their production of fronted sentences in the post- relative to the pre-test $(\mathrm{M}=.06, \mathrm{SD}=.42)$ than participants who only noticed it $(\mathrm{M}=.26, \mathrm{SD}=.38)$ (Figure 6).

For L1 speakers, the converging model for attention to syntax did not significantly differ from the simplest model ( $p=.29)$ but the converging model for attention to stimuli and task was a better fit than the simplest model $(p=.04)$ and it showed that there was a significant interaction between Section and attention to stimuli and task, $\beta=-.47(S E=0.16), z=-2.95$, $p<.005$ (Figure 5b). This indicated that L1 speakers who were more attentive to the stimuli and the task were less likely to show long-term priming. The converging model for noticing was not a better fit than the simplest model $(p=.06)$.

Overall, we found that in both groups of speakers, being more attentive to the stimuli and the task reduced participants' likeliness to show long-term priming. In L2 speakers, those who noticed and understood the target structure (i.e., who understood that there was an alternation between fronted and non-fronted TPs) showed a lower increase in production of fronted sentences in the post- relative to the pre-test than those who only noticed it (i.e., who only noticed that the sentences contained TPs).

\section{[Insert Figure 5 about here] \\ [Insert Figure 6 about here]}

\section{Motivation in the L2 speakers}

\section{Immediate priming}


The converging model for French learning motivation was a better fit than the simplest model ( $p=.03)$ and showed a significant main effect of Side, $\beta=-3.05(S E=.86), z$ $=-3.54, p<.001$, and a significant interaction between Side and this type of motivation $\beta=.52$ $(S E=.16), z=3.26, p<.005$. To further examine this interaction, we split the data by Side and in the rest of the paragraph, we only report effects related to French learning motivation (see OSF for a report of the full models). We found that there was a main effect of motivation $\beta=$ $.66(S E=0.27), z=2.48, p=.01$ only when the picture was presented on the right. When the picture was presented on the right, participants with a higher French learning motivation were more likely to produce a fronted sentence. The converging model for task-specific motivation did not significantly differ from the null model $(p=.06)$. In sum, French learning motivation related to fronted sentences production in the condition where the presentation of the temporal phrase did not align spatially with sentence position (i.e. to the left) suggesting that more motivated learners were able to overcome this presentational bias. French learning motivation did not relate to priming per se as there was no interaction between motivation and Prime Syntax.

\section{Long-term priming}

The converging model for French learning motivation was a better fit than the simplest model ( $p=.004)$. It showed that there was a significant interaction between Section and this motivation score indicating that as L2 speakers' French learning motivation increased, they were less likely to show long-term priming, $\beta=-.74(S E=0.26), z=-2.90$, $p<.01$ (Figure 7). There was also a significant interaction between Side and French learning motivation, $\beta=.77(S E=0.25), z=3.14, p<.01$. To understand these interactions better, we split the data by Side and applied Bonferroni correction with a threshold value of .025 . In the rest of the paragraph, we only report effects related to French learning motivation (see OSF for a report of the full models). We found that there was a significant interaction between Section and French learning motivation when the picture was presented on the left, $\beta=-.80$ $(S E=0.32), z=-2.54, p<.025$. In other words, as their French learning motivation increased participants were less likely to show long-term priming when the picture was presented on the left. The converging model for task-specific motivation did not significantly differ from the null model $(p=.40)$. Thus, only French learning motivation related to long-term priming of fronted sentences and only in the context of overcoming a bias to produce fronted 
sentences when the temporal phrase was presented to the left of the picture. No motivation scores were associated with an increase in priming effects.

\section{[Insert Figure 7 about here]}

\section{Discussion of Experiment 1}

Experiment 1 showed that both groups of speakers experienced immediate priming with and without lexical overlap in line with our predictions and other previous research targeting fronting alternations (Jackson \& Hopp, 2020; Jackson \& Ruf, 2017a, 2017b; Ruf, 2011). However, contrary to our predictions, this effect was not larger in L2 than in L1 speakers (see Ruf, 2011 for similar results): whilst we observed a two-way interaction between speaker group and prime structure, this was qualified by a three-way interaction with lexical overlap which indicated that the L2 speakers showed a greater lexical boost to priming (35\%) than L1 speakers (18\%) but very similar magnitudes of priming without lexical overlap (14\% and 13\% respectively). There was evidence of long-term priming in that speakers produced more fronted TPs in the post-test phase than in the pre-test phase and as predicted there was no lexical boost to long-term priming. However, contrary to expectations, this learning was not greater for L2 speakers, perhaps due to the lack of significantly greater immediate priming effects. We discuss the reasons for these findings in the general discussion.

As predicted by Chang et al. (2006)'s model, both attention and, to a certain extent, motivation related to priming effects. Yet surprisingly, they did not always relate to priming in the expected direction and they mostly affected long-term but not immediate priming (cf. Bock et al., 1992; Branigan et al., 2007; Ivanova et al., 2020; Schoot et al., 2019; Shin \& Christianson, 2012). Motivation only showed a relationship with participants' production of fronted sentences in relation to the side of the picture on which the temporal phrase was depicted. In the immediate priming phase, more motivated learners overcame a bias to produce non-fronted sentences when the picture appeared on the right. This effect was unrelated to priming. More motivated L2 speakers were also less likely to show long-term priming, particularly when the picture appeared on the left. Thus, it seems that L2 speakers with a higher motivation to learn French relied less on the visual cues of the stimuli to produce target sentences. Furthermore, when both groups of speakers were more attentive to the stimuli and the task, they were less likely to show long-term priming; L2 speakers who noticed and understood the syntactic alternation showed the same effect. Thus, contrary to 
our prediction that attention would increase priming, it had the opposite effect. This may be because participants who were paying attention to the task deliberately chose to use the preferred non-fronted form or to avoid the dispreferred target form. Finally, contrary to our predictions, whether individual differences in attention and motivation related to syntactic priming was not affected by the presence or absence of lexical overlap.

One possible explanation for why some of our results were not in line with our predictions is that the syntactic alternation used in this experiment was not suitable for detecting between group differences. A between-group difference in immediate abstract priming effects may be more likely to arise when the targeted structure has a lower baseline frequency or when it is syntactically more complex. Therefore, in Experiment 2, we tested priming on a target structure that is more complex and less frequent. Based on the model's predictions (Chang et al., 2006), both groups of speakers should be more likely to experience prediction error when processing such primes leading to greater priming. Furthermore, L2 speakers may be particularly affected by these factors due to their lower level of experience with the target language overall. Consequently, we may be more likely to observe whether immediate and long-term priming effects are larger in L2 speakers than in L1 speakers and whether individual differences in attention and motivation relate to immediate priming without overlap.

\section{Experiment 2- Active-Passive alternation}

We examined syntactic priming for French active-passive syntactic structures (e.g., le pirate suit le marin (The pirate is following the sailor) vs. le marin est suivi par le pirate (the sailor is being followed by the pirate)), with and without lexical overlap between prime and targets in English-speaking learners of French and L1 speakers of French.

\section{Methodology}

Participants

The same 104 L2 and 100 L1 speakers completed Experiment $2^{2}$. We excluded 13 participants who reported being native speakers of both languages or who were not L1 or L2 native speakers of French or English. We also excluded 3 participants due to experimenter error (misaligned prime-target pairs) and 2 participants who produced only reversed actives

\footnotetext{
${ }^{2}$ Recall that Experiment 2 was actually completed first since the fronted items included many active transitive sentences that might have counteracted the passive priming we sought to elicit in this experiment.
} 
(and non-reversed passives sentences). As a result, the analyses included 91 L2 speakers (72 female); 42 in the no lexical overlap condition and 49 in the lexical overlap condition, and 95 L1 speakers ( 75 female); 45 in the no lexical overlap condition and 50 in the lexical overlap condition. Participants were aged 18 to 28 years, $(M=19.77)$.

\section{Design}

Experiment 2 had the same design as Experiment 1.

\section{Materials}

Prime/target cards

We created 36 target items using six French verbs (pourchasser (chase), suivre (follow), taper (punch), gronder (scold), embrasser (kiss), gifler (slap)) six times each with different combinations of animate agent and patient characters. Items were based on stimuli from Branigan et al., (2000) and Hardy, Messenger and Maylor, (2017). Each target verb appeared once in the pre-test ( 6 items), four times in the priming phase (24 items) and once in the post-test (6 items).

For the priming phase, we created a prime item with and without lexical overlap (of the verb) for each target item. To create 24 prime items with lexical overlap, the target verbs were used four times each with new combinations of characters. To create 24 prime items without lexical overlap we paired each target verb with one of six different verbs (frapper (kick), pousser (push), toucher (touch), tuer (shoot), tirer (pull), chatouiller (tickle)), each of which were used four times with different combinations of characters. Prime items had an associated active and passive description, see Figure 8 and Appendix B.

\section{[Insert Figure 8 about here]}

In the priming phase, prime-target pairs were separated by two filler pictures (a prime and a target filler picture) and in the pre-/post-test sections target pictures were separated by three filler pictures. We created 84 filler pictures in total using intransitive verbs (depicted with two characters, such as "the monks are crying") and ditransitive verbs (depicted with two characters and an object, such as "the monk is selling the artist a cup"). 36 appeared in the target set ( 6 in the pre-test, 24 in the priming phase and 6 in the post-test) and 48 appeared in the prime set (12 in the pre-test, 24 in the priming phase and 12 in the post-test). 
In total, there were 72 pictures (36 targets and 36 fillers) in the participant's description set and 72 pictures ( 24 primes and 48 fillers) in the experimenter's description set (see Appendix B). Items were depicted on individual cards $(10 \mathrm{~cm} \times 10 \mathrm{~cm})$, which included word labels (articles, nouns and verbs) to prevent problems of vocabulary retrieval. The position of the agent characters was counterbalanced to appear an equal number of times on the right and on the left side of the card. We created four lists of stimuli, two with lexical overlap and two without so that one version of each experimental prime item (active or passive) would appear in each list. Participants were randomly assigned to one of the four lists.

\section{Individual differences questionnaires}

We used the same questionnaires as in Experiment 1 to assess individual differences in attention, motivation and proficiency.

\section{Procedure}

See Experiment 1 for a description of the procedure.

\section{Scoring}

\section{Target sentences}

The analysis included complete active sentences containing a subject noun phrase with the agent produced first, followed by the verb and finally, an object noun phrase with the patient, and complete passive sentences containing a subject noun phrase with a patient in first position, followed by a form of the verb "to be" (i.e. "être"), a past participle and finally, a by-phrase (headed by 'par') with an agent. We ignored morphological errors, such as tense or agreement errors and naming errors in which participants used an alternative noun for a character (e.g., naming a character "le juge" (the judge) instead of "le professeur" (the teacher)). We included sentences in which one of the noun phrases was replaced by a pronoun or sentences in which two pronouns of distinct genders were produced, and sentences with complex noun phrases such as "le professeur frappe le tibia du clown (the teacher kicked the clown's leg).” All remaining responses, including reversed passives and actives and responses that were not an active or passive, were coded as 'other' and excluded from the analyses. L2 speakers produced 2822 active and passive target sentences and 453 responses scored as other, L1 speakers produced 3078 active and passive target sentences and 
339 responses scored as other; see Table 6 for a breakdown of response types by conditions and experiment phase.

\section{[Insert Table 6 about here]}

\section{Individual differences}

We used the results of the attention and awareness questionnaire, the motivation questionnaire and the proficiency questionnaire, as described in Experiment 1. To assess noticing of the target structure (which was specific to the priming task), participants' responses were given a score of 2 (henceforth "Noticing 2") if they had noticed and understood the alternations (Schmidt, 1990), i.e. they were able to name, describe or give examples of the passive/active sentences. They received a score of 1 , which corresponded to noticing only (Schmidt, 1990) (henceforth "Noticing 1") if they mentioned some aspect of the passive, for example, the use of past participles or past tense, or "indirect vs. direct form" to describe the actions or that who was doing what to whom mattered. They received a score of 0 if they did not refer to the passive/active alternation or its features in any way.

Although the same participants took part in Experiment 1 and 2, we did not exclude exactly the same participants from both experiments. Thus, we report in Table 7 the descriptive statistics for the participants who were included in the Experiment 2 analysis. L2 French speakers showed a mean score of 5.59 (range 3.5-7) and L1 speakers showed a mean score of 5.19 (range 1.5-7) for attention to the task; see Table 7 for a breakdown by condition. For attention to syntax, L2 French speakers showed a mean score of 5.18 (range 17) and L1 speakers showed a mean score of 5.20 (range 1-7); see Table 7 for a breakdown by condition. With regards to noticing, $25.3 \%$ of L2 French speakers scored 2, 25.3\% scored 1 and 49.4\% scored 0, whereas 36.8\% of L1 French speakers scored 2, 28.4\% scored 1 and $34.7 \%$ scored 0 ; see Table 8 for a breakdown by condition. L2 speakers had an average rating of 5.37 out of 7 (range 2.53-6.65) for French learning motivation and 4.98 (range 3.44-6.22) for task-specific motivation; see Table 7 for a breakdown by overlap condition. Overall, L2 speakers had an average proficiency of 6.31 (range 1.5-9); see Table 7 for a breakdown by overlap condition.

\section{[Insert Table 7 about here] \\ [Insert Table 8 about here]}

\section{Analysis and results}


Unless otherwise stated, we followed the same procedure for statistical analysis as in Experiment 1. First, we focused on the comparison of syntactic priming effects between L1 and L2 speakers with and without lexical overlap over two different time courses: immediate priming and long-term priming. Second, we explored the effects of individual differences on each type of priming. We used the lme4 package (Version 1.1.21) for the analyses of immediate priming and the blme package (Version 1.0.4) for the analyses of long-term priming (where most participants did not produce passives in the pre-test; such zero cells led to convergence issues for analyses in lme4). As the response frequencies presented in Table 6 confirmed that speakers of both groups were more likely to produce active than passive sentences in the pre-test, we analysed the effect of priming on passive responses. The dependent variable was coded as $0=$ active structure and $1=$ passive structure. The factorial predictors Prime Syntax (active vs. passive), Section (pre-test vs. post-test), Lexical Overlap (with vs. without) and Speaker Group (L2 vs. L1 speakers) were sum contrast coded to have a mean of 0 and a range of 1 prior to analysis.

\section{L1 vs. L2 immediate and long-term priming with and without lexical overlap}

As in Experiment 1, we started with a full model which we then reduced to find the simplest model that did not differ from the full model (best model). For immediate priming, we built a full model including as fixed effects Prime Syntax, Lexical Overlap, Speaker Group and the interaction between all four factors. The model also included random intercepts for participants and items and by-subject random slopes for Prime Syntax and by-item random slopes for Prime Syntax, Lexical Overlap, Speaker Group and their interactions. For longterm priming, we built a model which included as fixed effects Section, Lexical Overlap, Speaker Group and the interaction between these three factors. We included random intercepts for subjects and items as well as by-subject random slopes for Section and by-item random slopes for Speaker Group and Lexical Overlap and their interaction.

\section{Immediate priming}

Figure 9 shows the mean predicted probability of passive response by Prime Syntax, Lexical Overlap and Speaker Group condition. The best model included Prime Syntax, Lexical Overlap and Speaker Group as well as the interaction between them as fixed effects and by-subject random slopes for prime syntax. It showed that there was a significant main effect of Prime Syntax whereby participants produced more passive targets after passive primes $(\mathrm{M}=0.30, \mathrm{SD}=0.46)$ than after active primes $(\mathrm{M}=0.10, \mathrm{SD}=0.29)$. We also found 
a significant main effect of Lexical Overlap whereby the speakers of both groups produced more passive targets in the lexical overlap condition $(\mathrm{M}=0.26, S D=0.44)$ than in the condition without lexical overlap $(\mathrm{M}=0.12, \mathrm{SD}=0.33)$ and a significant main effect of Speaker Group as L2 speakers produced more passive targets $(\mathrm{M}=0.24, \mathrm{SD}=0.43)$ than L1 speakers $(\mathrm{M}=0.15, \mathrm{SD}=0.36)$. We found a significant two-way interaction between Prime Syntax and Lexical Overlap: passives were 34.6\% more likely following passive primes than active primes with lexical overlap whereas they were only $5.2 \%$ more likely following passive primes than active primes without lexical overlap. There was a significant two-way interaction between Speaker Group and Prime Syntax: the L2 speakers were 30.8\% more likely to produce passives following passive primes than active primes, whereas L1 speakers were $11.5 \%$ more likely to prime. These effects are qualified by a significant three-way interaction between Prime Syntax, Lexical Overlap and Speaker Group (see Table 9 for details) suggesting that the effect of lexical overlap on priming differed between groups.

To further examine the three-way interaction, we split the data by Speaker Group. The model for L2 speakers revealed a significant main effect of Prime Syntax, $\beta=2.39$ (SE = $0.41), z=5.85, p<.001$, such that they produced more passive sentences after passive primes $(\mathrm{M}=0.40, \mathrm{SD}=0.49)$ than after active primes $(\mathrm{M}=0.09, \mathrm{SD}=0.29)$ and a significant main effect of Lexical Overlap, $\beta=1.10(S E=0.44), z=2.51, p<.025$, such that they produced more passives with $(\mathrm{M}=0.32, \mathrm{SD}=0.47)$ than without overlap $(\mathrm{M}=0.15, \mathrm{SD}=0.36)$. Additionally, there was a significant interaction between Prime Syntax and Lexical Overlap, $\beta=3.50(S E=0.63), z=5.59, p<.001$, indicating a significant lexical boost $(42 \%)$ to priming: participants in the lexical overlap condition produced $51 \%$ more passives after passive primes than active primes whereas those in the condition without overlap produced only $9 \%$ more passives after passive primes than active primes. Simple main effects analyses showed a significant effect of Prime Syntax in the lexical overlap condition, $\beta=4.17$ (SE = $0.62), z=6.74, p<.001$, such that L2 speakers produced more passives after passive primes than after active primes but there was no significant main effect of Prime Syntax without lexical overlap, $p=.30$.

The model for L1 speakers revealed a significant main effect of Prime Syntax, $\beta=$ $1.48(S E=0.34), z=4.32, p<.001$, such that L1 speakers produced more passive sentences after passive primes $(\mathrm{M}=0.21, \mathrm{SD}=0.41)$ than after active primes $(\mathrm{M}=0.10, \mathrm{SD}=0.30)$ and a significant main effect of Lexical Overlap condition, $\beta=1.18(S E=0.40), z=2.92$, $p<.025$, such that they produced more passives with $(M=0.21, S D=0.41)$ than without 
overlap $(\mathrm{M}=0.09, \mathrm{SD}=0.29)$. Additionally, there was a significant interaction between Prime Syntax and Lexical Overlap, $\beta=1.42(S E=0.47), z=3.04, p<.025$, indicating a significant lexical boost (17\%) to priming: participants in the lexical overlap condition produced $20 \%$ more passives after passive primes than active primes whereas those in the condition without overlap produced only $3 \%$ more passives after passive primes than active primes. Simple main effects analyses showed there was a significant effect of Prime Syntax in the condition with lexical overlap, $\beta=2.28(S E=0.45), z=5.09, p<.001$, such that L1 speakers produced more passives after passive primes than after active primes but there was no significant main effect of Prime Syntax in the condition without lexical overlap, $p=.65^{3}$.

To summarize, the overall analyses showed that immediate priming was stronger with lexical overlap and in L2 than in L1 speakers. Subsequent analyses showed that though priming without overlap was numerically larger for L2 speakers than L1, it was not significant within either group. Whereas in both groups of speakers there was significant priming in the condition with lexical overlap, the lexical boost to priming was greater in L2 speakers $(42 \%)$ than in L1 speakers $(17 \%)$.

\section{[Insert Figure 9 about here] \\ [Insert Table 9 about here]}

\section{Long-term priming}

For long-term priming (Figure 10), the best model, that did not significantly differ from the full converging model $(p=.10)$ but was a better fit than the null model $(p<.001)$, did not include random slopes nor any interactions between fixed effects (Table 10). This model showed that there was a significant main effect of Section such that participants produced more passive sentences in the post- $(\mathrm{M}=.19, \mathrm{SD}=.39)$ than in the pre-test $(\mathrm{M}=.00, \mathrm{SD}=.07)$. There was also a significant main effect of Speaker Group such that L2 speakers produced more passive sentences $(\mathrm{M}=.14, \mathrm{SD}=.35)$ than $\mathrm{L} 1$ speakers $(\mathrm{M}=.06, \mathrm{SD}=.24)$ across overlap conditions and a significant main effect of Lexical Overlap such that, across groups, participants produced more passives in the condition with $(\mathrm{M}=.13, \mathrm{SD}=.33)$ than in the condition without overlap $(\mathrm{M}=.07, \mathrm{SD}=.26)$.

\footnotetext{
${ }^{3}$ We also split the data by Lexical Overlap to analyse the effect of Speaker Group. It showed that priming magnitude was larger in L2 than L1 speakers only in the condition with lexical overlap. We uploaded the outcome of this model on OSF (see Supplementary material).
} 
The main effect of Section shows that there was long-term priming across speaker groups and overlap conditions. Since including interactions between fixed effects in the model did not improve its fit, we can conclude that there were no significant interactions between Section, Lexical Overlap and Speaker Group. However, since participants of both groups produced passives for less than $0.5 \%$ of their transitive responses in the pre-test (Figure 10 and Table 6), the significant effects of Speaker Group and Lexical Overlap were likely driven by differences in passives production emerging in the post-test. In other words, the significant effect of Speaker Group seems to be driven by L2 speakers producing more passives than L1 speakers in the post-test. The significant effect of Lexical Overlap across groups is similarly likely to be driven by participants producing more passives in the post-test in the overlap than in the no overlap condition.

To summarise, following the priming phase, participants continued to produce more passives in the post-test phase which did not contain primes than they had in the pre-test (baseline) phase indicating long-term effects of the priming phase; these effects appear greater in the L2 speaker group and in the lexical overlap condition.

\section{[Insert Figure 10 about here] \\ [Insert Table 10 about here]}

\section{Effects of individual differences}

As for Experiment 1, in the second part of the analysis, we tested the effect of each individual score in separate models. We first examined whether proficiency related to syntactic priming in L2 speakers to decide whether it should be included as a covariable in the models for each priming type. For immediate priming, we used the final model for L2 speakers' immediate priming and added proficiency and its interactions with each fixed effect as a predictor. The model showed a significant main effect of proficiency, $\beta=0.41$ (SE = $0.12), z=3.40, p<.001$, such that L2 speakers were more likely to produce passive sentences as their proficiency increased. While the absence of an interaction with Prime Syntax suggests that proficiency did not directly relate to priming, this observation shows that more proficient L2 speakers were more likely to produce passive sentences overall. We thus included proficiency as an additional predictor in the models investigating the effect of individual differences in attention and motivation on L2 speakers' immediate priming and we 
tested the effects of speaker attention on immediate priming in separate models for L2 and L1 speakers.

We also analysed the effect of proficiency on long-term priming in L2 speakers. To do so, we used the final model, removed Speaker Group as a fixed effect and added the twoways interactions between Section and proficiency and Lexical Overlap and proficiency as fixed effects. The model only showed an interaction approaching significance between Section and proficiency $(p=.06)$. Thus, we did not include proficiency in the models testing the effect of individual differences in attention and motivation on long-term priming.

\section{Attention in the L1 and L2 speakers}

\section{Immediate priming}

In L2 speakers, the converging models for attention to syntax, attention to stimuli and task and noticing did not significantly differ from the simplest model $(p=.12, p=.96$ and $p=.13$ respectively). Likewise, in L1 speakers, the converging models for attention to syntax and attention to stimuli and task did not significantly differ from the simplest model $(p=1$ and $p=.2$ respectively). The model for noticing only converged without random slopes and was a better fit than the simplest model $(p<.001)$. However, it did not show a significant effect of noticing on immediate priming, $p \mathrm{~s}>.59$. Thus, we found no evidence for an effect of any of the three attention scores on immediate priming of passives in both groups of speakers.

\section{Long-term priming}

The models for attention to syntax and attention to stimuli and task did not significantly differ from the simplest model ( $p=.47$ and $p=.36$ respectively). The model for noticing was a better fit than the simplest model $(\mathrm{p}<.001)$. There was a significant main effect of noticing, $\beta=1.25(S E=0.63), z=2.00, p=.045$, such that participants produced more passive sentences overall when they noticed the target structure (Noticing $1 \& 2$ combined) $(\mathrm{M}=.12, \mathrm{SD}=.33)$ than when they did not notice it at all $(\mathrm{M}=.07, \mathrm{SD}=.25)$. There were also significant interactions between Lexical Overlap and the comparison of not noticing vs Noticing $1 \& 2$ combined, $\beta=-1.73(S E=0.78), z=-2.22, p<.05$, and between Speaker Group and the comparison of Noticing 1 to Noticing 2, $\beta=-1.72(S E=0.73), z=-2.36$, $p<.05$.

To analyse these interactions further, we split the data by Lexical Overlap and then by Speaker Group. We applied Bonferonni corrections from then on with a threshold value of 
.025 to assess significance levels and in the rest of the paragraph, we only report effects related to noticing (see OSF for a report of the full models). There was no effect of noticing in the condition with overlap. In the condition without overlap, there was a significant main effect for the comparison of not noticing vs Noticing $1 \& 2$ combined, $\beta=2.33$ ( $S E=1.02), z$ $=2.28, p<.025$, such that participants who at least noticed the target structure produced overall more passives $(\mathrm{M}=.10, \mathrm{SD}=.31)$ than those who did not notice it at all $(\mathrm{M}=.03$, $\mathrm{SD}=.18$ ), see Figure 11. With Bonferonni corrections applied, there was no effect of noticing in either group of speakers.

Overall, we found that only noticing related to long-term priming. Specifically, in the condition without overlap, participants who at least noticed the target structure produced more passive responses than participants who did not notice it at all. Given that participants produced almost no passive sentences in the pre-test, we can conclude that these effects were driven by the production of passive sentences in the post-test.

\section{[Insert Figure 11 about here]}

\section{Motivation in the L2 speakers}

The converging models for immediate priming for both motivation types did not significantly differ from the simplest model ( $p=.32$ and $p=.40$ respectively). The two converging models for long-term priming did not differ significantly from the simplest model ( $p=.17$ for French learning motivation, $p=.1$ for task-specific motivation). Thus, we found that neither French learning motivation nor task-specific motivation related to syntactic priming of passive sentences.

\section{Discussion of Experiment 2}

Surprisingly and contrary to our predictions, this experiment did not show significant immediate syntactic priming in either group of speakers when there was no lexical overlap between prime and target sentences, though both groups showed stronger priming when there was lexical overlap and this effect was greater in L2 speakers than in L1 speakers. This runs counter to our predictions that a between-group difference would only emerge in the case of priming without lexical overlap - though this priming effect for L2 speakers was numerically higher, this difference did not reach significance - and that lexical overlap should attenuate this difference. In comparison to the results of Experiment 1, this result is also not consistent 
with our prediction that participants of both groups should have been more likely to show immediate priming effects without lexical overlap on the active/passive than on the fronted/non-fronted TP syntactic alternation. We found evidence of long-term priming in that speakers produced more passives in the post-test phase than in the pre-test phase. Although we do not observe an interaction between experiment phases and speaker groups, we did find that L2 speakers produced more passive sentences than L1 speakers when comparing the preand post-tests. Since passives were only produced in the post-test by each group, this suggests a greater effect of long-term priming in L2 speakers. Interestingly, the main effect of lexical overlap we observed even suggests that long-term priming could be greater in the condition with lexical overlap than in the condition without. We discuss potential explanations for this pattern of results in the general discussion.

Contrary to Experiment 1, the analyses showed limited evidence for a role of individual differences in attention and motivation (and proficiency for L2 speakers) in modulating priming effects for passives. Only noticing led to an increased production of passive sentences without lexical overlap in the post-test. Thus, even if there was no overall immediate priming without overlap, noticing the target structure during the priming manipulation increased the likelihood of producing passives in the post-test. By contrast, the fact that individual differences did not explain priming with lexical overlap is less surprising if priming with overlap relies on a separate mechanism to the error-based learning mechanism that supports abstract priming.

One of the most striking findings across Experiments 1 and 2 is that the patterns of syntactic priming effects differed between alternations even though the same participants took part in both experiments. For example, the same participants showed significant priming of fronted sentences but not of passives; L2 speakers showed increased production of passives across the experiment compared to L1 speakers but not of fronted sentences; within the same individuals, noticing increased priming of passives but reduced priming of fronted sentences across the experiment; individual variation in motivation related to production of fronted, but not of passive sentences. If, however, syntactic priming effects without lexical overlap depend on individual learning rates and if syntactic priming effects with lexical overlap rely on individuals' short-term memory (Chang et al., 2006), we would predict consistent priming effects within individuals and lexical overlap conditions across syntactic alternations. In other words, in both conditions, the participants who are the most likely to show priming for one structure should also be more likely to show priming on the other 
structure, even if that priming effect is also affected by structural preferences. To investigate this prediction, we ran a combined analysis of both experiments.

\title{
Combined analysis of Experiments 1 and 2
}

We ran a correlational analysis to examine whether the individual magnitude of immediate priming and the individual magnitude of long-term priming for each syntactic alternation were related in each groups of speakers. The magnitude of immediate priming effects was calculated as the difference between the proportion of target structures (fronted sentences out of all fronted and non-fronted sentences for Experiment 1; passives out of all transitive responses for Experiment 2) produced after a prime sentence with the target structure vs. the alternative structure. Long-term priming corresponded to the increase in proportion of target structure production in the post-test relative to the pre-test.

To compute these comparisons, we ran eight Pearson correlations to compare the magnitude of immediate priming and long-term priming effects for the two syntactic alternations for each speaker group and overlap condition separately (Table 11). We only included the participants who were included in both Experiment 1 and Experiment 2 $(\mathrm{N}=186)$.

We found a significant correlation between the magnitude of immediate priming effects with lexical overlap for the active/passive and for the fronted/non-fronted alternations for both L1 and L2 speakers (Figure 12). This pattern of results shows that, participants who were more likely to prime on the active/passive alternation with lexical overlap were also more likely to prime on the fronted/non-fronted TP alternation. There was also a significant correlation in long-term priming with lexical overlap for L1 speakers (Figure 13): L1 speakers who showed the most long-term priming on the active/passive alternation also experienced more long-term priming on the fronted/non-fronted TP alternation. There were no significant correlations for the conditions without lexical overlap.

\author{
[Insert Table 11 about here] \\ [Insert Figure 12 about here] \\ [Insert Figure 13 about here]
}

\section{General discussion}

In this study, we examined whether evidence from L2 and L1 speakers of French would support the predictions of the error-based implicit learning model of language 
processing regarding between- and within- group variation in syntactic priming (Chang et al., 2006). Specifically, we focused on whether immediate and long-term priming without lexical overlap would be larger in L2 speakers than in L1 speakers; whether lexical overlap would cancel out group differences and lead to a lexical boost for immediate but not long-term priming; and whether individual differences in attention and motivation would affect both types of priming in both speaker groups. We tested these effects with two different structural alternations to examine whether the nature of the syntactic alternation also played a role in the degree of priming. Finally, we tested whether the degree of priming an individual showed on one structure related to the degree of priming they showed on another structure both with and without lexical overlap.

We found that the same participants showed abstract priming (i.e, without lexical overlap) for the fronting alternation (Experiment 1) but not for the active/passive alternation (Experiment 2) but we also found long-term priming for both alternations. There was no evidence of larger immediate priming effects in the absence of lexical overlap in L2 than in L1 speakers in either experiment but, though the long-term priming effect for the fronting alternation did not vary between L2 and L1 speakers, L2 speakers produced more passives across the experiment than L1 speakers. Contrary to our prediction, priming with lexical overlap did vary across groups: for both alternations, L2 speakers showed larger lexical boost effects and produced more target structures than L1 speakers in the conditions with overlap. Though the lexical boost to immediate priming of fronted sentences did not extend to the post-test phase, for passives, the effect of the lexical boost did appear to persist with participants in the lexical overlap condition producing more passives in the post-test than those in the condition without overlap. We found that the extent to which individual differences in attention and motivation affected syntactic priming effects depended on the targeted syntactic alternation. Motivation only showed a relationship with L2 speakers' production of fronted sentences and only in relation to the way the temporal phrase was depicted. Attention related to long-term priming but in opposite directions for passives and fronted sentences. The most striking result of the study is perhaps that syntactic priming patterns varied highly across syntactic alternations, even within individuals, though lexical overlap seems to attenuate this difference, as indicated by the correlations across syntactic alternations for immediate priming in both groups and for long-term priming in L1 speakers. We consider in turn the implications of these findings for the error-based learning model of syntactic priming, and for other models and explanations of priming. 
Immediate and long-term priming without lexical overlap in L2 vs. L1 speakers

Error-based implicit-learning models of priming predict that syntactic priming should have both immediate and lasting effects on speakers' choice of structure and further that the degree of syntactic priming should relate to the magnitude of error a speaker experiences when processing input sentences. Such error is predicted to be larger in speakers who are learners of the language as opposed to adult native speakers (Chang et al., 2006). Since the model proposes that these learning experiences accumulate, larger immediate priming effects should also lead to larger long-term learning effects of priming. Our results provide mixed evidence to support these predictions.

While there was immediate priming for the fronted/non-fronted TP alternation in line with past research in L1 (Jackson \& Hopp, 2020) and L2 speakers (Jackson \& Hopp, 2020; Jackson \& Ruf, 2017a, 2017b; Ruf, 2011), the effect was equivalent across groups. For the active/passive alternation, though the magnitude of priming was numerically larger for L2 than for L1 speakers, neither group showed a significant effect of priming in the condition without lexical overlap. One possibility for the lack of a significant abstract priming effect for passives is that, once priming was introduced, participants produced passives in both the active and passive priming condition which actually attenuated the effect of prime condition as measured on a trial-by-trial basis. By comparison to the baseline phase where no L2 speakers produced any passives and L1 speakers produced only two passives (less than $1 \%$ of responses), participants' production of passives increased rapidly in the priming phase: $15 \%$ of L2 speakers' and 9\% of L1 speakers' responses across the priming phase were passive. However, these above baseline levels of production occurred in both prime conditions. Following active primes, $11 \%$ of L2 speakers' and 8\% of L1 speakers' responses were passive, while following passive primes, $20 \%$ of L2 speakers' and 10\% of L1 speakers' responses were passive, thus reducing the likelihood of observing a trial-by-trial priming effect. As such, though we did not observe immediate priming, contrary to many previous studies of syntactic priming (Bock, 1986; Branigan \& Messenger, 2006; Hardy et al., 2017; Kim \& McDonough, 2008; Schoot et al., 2019), it would be premature to interpret this null effect as indicating that there was no effect of the syntactic primes since, relative to the pretest phase, there was a clear increase in passive production within (and after) the priming phase.

Nonetheless, the fact remains that immediate priming of fronted TPs did not differ between L2 and L1 speakers despite a significant effect. In line with this, Jackson and Hopp (2020) only found a marginally significant interaction between prime syntax and speaker 
group when comparing priming of fronting of adverbial phrases in L1 and L2 speakers. This absence of a group difference could be due to the lack of syntactic complexity of the targeted structure, which may prevent L2 speakers from experiencing larger prediction errors than L1 speakers. In line with this, L1 speakers actually showed a greater increase in fronting production $(23 \%)$ in the priming phase relative to the pre-test than did L2 speakers (18\%), unlike for passive priming where L2 speakers exhibited a numerically larger increase (15\%) in passive production in the priming phase relative to the pre-test than did L1 speakers $(9 \%$, as noted above). These data provide a hint that L2 speakers may have been more influenced than L1 speakers by priming of more syntactically complex structures. An alternative explanation for our results is that our L2 speakers were not suitably non-proficient to show a greater magnitude of priming relative to L1 speakers.

In line with implicit learning models of priming, we did observe long-term effects of the priming phase with participants producing more target structures in the post-test relative to the pre-test phases. Thus, cumulative exposure to passive and fronted sentences across the priming phases impacted the participants' language representations for these structures. But our evidence regarding the strength of this effect in L2 vs L1 speakers was more mixed. There was no difference between speaker groups for fronted sentence priming. However, given that we only anticipated group differences in long-term priming to occur if immediate priming was larger in L2 than in L1 speakers, this lack of effect is not surprising (see Jackson \& Hopp, 2020 for similar results). Despite no significant difference in immediate priming of passives for L2 and L1 speakers, we did observe a speaker group difference when examining long-term priming effects. This is in line with our prediction that group differences may be more likely to emerge on a more complex syntactic structure, though we did not predict that this effect would be isolated to long-term priming.

Previous findings in the literature have also produced mixed results in this area. Studies with child learners of English similarly fail to show the interaction between priming effects and age group that would indicate stronger susceptibility to priming in children than adults (Branigan \& MacLean, 2016; Branigan \& Messenger, 2016) though some studies have reported larger effects sizes for child priming than adult in the absence of a significant interaction (Rowland et al., 2012). Other studies comparing L2 and L1 speakers have failed to find the predicted difference in priming effects for learners versus native speakers (Abrahams et al., 2019; Flett, 2006, experiment 3; Ruf, 2011). Our results indicate that the syntactic alternation being primed may be relevant to whether between group differences emerge. 


\section{Immediate and long-term priming with lexical overlap in L1 and L2 speakers}

Syntactic priming with lexical overlap is widely found to be larger than priming without and this lexical boost to priming is typically a short-lived effect (Hartsuiker et al., 2008; Mahowald et al., 2016). To explain this, the error-based implicit learning model of syntactic priming postulates that when there is lexical overlap between the prime and the target, boosted priming effects are based on the retrieval of the prime form from short-term memory. This implies that syntactic priming with lexical overlap should not lead to betweengroup differences that are based only on magnitude of prediction error. Again, our results are compatible with some but not all of these expectations. Both groups of speakers experienced larger priming effects with lexical overlap than without, in line with previous research in L1 (Branigan et al., 2000; Mahowald et al., 2016; Pickering \& Branigan, 1998) and L2 speakers (Flett, 2006; Jackson \& Ruf, 2017a, 2017b; Kim \& McDonough, 2008; Ruf, 2011). We also observed that more participants noticed the target structures of passives and fronted structure in the condition with overlap than without. This would support the idea that priming with lexical overlap relies on more explicit memory processes.

Though we did not expect to observe group differences in the lexical overlap condition, we found that, on the contrary, the lexical boost effect was larger in L2 than in L1 speakers and, in the lexical overlap condition, L2 speakers produced more target structures than L1 speakers for both alternations, in contrast to previous research (Flett, 2006; Ruf, 2011). One possible explanation is that, while both groups of speakers may rely more on explicit memory processes with lexical overlap, L2 speakers are more likely to do so than L1 speakers because they benefit more from such facilitation of their L2 language production. For example, if the target verb form of the passive construction is provided, re-using that form may make L2 speakers feel more confident when producing their own sentences. It may even help them overcome a lack of knowledge of past participles, for instance. Such an explanation would not be incompatible with the implicit learning model, nor with transient activation models of syntactic priming which imply a more explicit memory process for the lexical boost effect (Chang, Janciauskas \& Fitz, 2012; Hartsuiker \& Bernolet, 2017). Since the lexical boost should be a short-lived effect, we did not expect to see the lexical boost to priming persist into the post-test phase. Concordantly, there was no lexical boost to long-term priming of fronted sentences. However, participants in the lexical overlap condition produced more passives across the experiment. This finding suggests that syntactic experiences with lexical overlap can accumulate and persist in the same way as those 
without. When processing prime sentences in the lexical overlap condition, participants would experience learning via prediction processes as well as generating a short-term explicit memory of the form. Thus, even in the lexical overlap condition, we would expect long-term priming effects. However, that this persistence effect was greater in the condition where priming always involved lexical overlap and therefore was boosted by short-term memory of the form is not clearly consistent with any current model of syntactic priming. The activationbased model (Pickering \& Branigan, 1998; Pickering \& Ferreira, 2008) does not predict longterm lexical boost effects and hybrid models (Malhotra et al., 2008; Reitter et al., 2011) make similar predictions as the error-based implicit learning model of syntactic priming (Chang et al., 2006). It is unlikely that the lack of an interaction between long-term priming and lexical overlap condition resulted from the timing of the post-test phase since other research shows a rapid decay of priming with lexical overlap when measured on individual trials: one or two intervening fillers dampens the boost to priming from lexical overlap (Hartsuiker et al, 2008; Branigan \& MacLean, 2016). One possible explanation for why the boosted priming effects in the lexical overlap condition led to greater use of passives but not fronted sentences beyond the priming phase is that it facilitated participants' production of this infrequently-used target structure. Essentially, participants' increased production of passives during the immediate priming phase with lexical overlap, (i.e. the observed lexical boost effect), may have provided them with an extra opportunity to practice producing the target structure and the effects of this training then persisted into the post-test. Such a facilitation effect should be more likely to occur for priming of passives which are more complex and infrequent; recall that participants did not produce passives in the pre-test. By contrast fronted sentences are less complex and participants produced these with a higher frequency in the pre-test than passives. Alternatively, due to their rarity in oral interactions (as demonstrated by the pre-test measurements, Table 6 and Figure 10), passives may be more noticeable and participants' explicit memory of passive sentences may therefore persist for longer than their explicit memory of fronted sentences, thereby influencing their production for longer. It is worth noting that more participants reported noticing for passives (63) than fronted sentences (44) in the condition with lexical overlap.

\section{Effect of individual differences in attention and motivation}

The error-based implicit learning model of syntactic priming provides a mechanism for explaining the individual variation observed in priming effects within and across experiments (Mahowald et al., 2016). Since abstract priming is based on an individual's 
learning rate - the degree to which they detect and respond to error in their predictions priming effects should vary across individuals. This variation may be due to differences in a speaker's knowledge of the language, their attention to the language or the task, their motivation to speak the language well or to complete the task, amongst other things. On the other hand, the model also predicts that, because priming with lexical overlap is boosted by short-term memory and does not rely on the mechanism affected by learning rate, individual differences in attention and motivation should not modulate priming with overlap.

Individual variation in motivation only related to production of fronted sentences. More precisely, more motivated L2 speakers were more able than less motivated participants to ignore the side of picture presentation when formulating their own sentences. A potential explanation for why motivation did not otherwise relate to syntactic priming is that the tested L2 speakers did not vary enough in terms of motivational profiles for an effect to be detectable: they mostly reported high levels of motivation both towards learning French and towards the task. Most participants were recruited in the French department of the university and had therefore chosen to study French, and all participants were volunteers for the study and thus may represent a particularly motivated subset of learners within this group.

In line with previous research and with the model's predictions, our data show that individual differences in attention sometimes related to priming of both alternations but in different ways: while higher attentional levels increased passive priming without overlap (cf. Branigan et al., 2007; Ivanova et al., 2020; Schoot et al., 2019), they decreased priming of fronted sentences. On the one hand, noticing the transitive alternation may have led to increased long-term priming effects because it facilitated participants' detection of mismatches between their predictions and the language input and thus the learning that they experienced. By contrast, in the fronted/non-fronted TP alternation, participants with higher attention levels and noticing scores may have become more aware of the manipulation and voluntarily decided to avoid producing the target structure. This "negative" effect of attention on the fronting alternation is somewhat in line with other studies also targeting priming of fronted/non-fronted adverbial phrases. In Jackson and Ruf (2017b)'s study, while many of their participants reported having noticed the targeted form, they did not all report relying on the syntax of their interlocutor to formulate their own sentences. This could indicate that for this alternation, voluntary decisions to avoid or copy the target structure may play a more preponderant role than for the transitive alternation. 
Given that the magnitude of priming without overlap is determined by an individual's learning rate and that priming with overlap relies on an individual's short-term memory (Chang et al., 2006), the model predicts that the degree of priming an individual shows with one structure should relate to the degree of priming they show with the other structure in both conditions (see also Branigan \& Messenger, 2016). However, while the effects of lexical boost were consistent across structures, and we observed within-individual consistency for priming in the case of lexical overlap, abstract priming effects were only significant for the fronted/non-fronted alternation and there was no within-individuals relationship between abstract priming for these structures. On the one hand, this provides perhaps the most striking evidence for a dissociation between the mechanisms underlying priming with and without lexical overlap as predicted by the error-based learning model (Chang et al., 2006). Priming with overlap probably relies on participants' short-term explicit memory whose capacities remain the same across syntactic structures. This is also supported by the fact that more participants of both groups noticed the target structures in the condition with overlap (107) than in the condition without (78). On the other hand, the fact remains that we did not observe the expected consistency in individuals' immediate and long-term priming magnitude across structures without overlap. While the reason for this remains largely unclear and would require further investigation, there are a few possible explanations. First, it could be that the processing of transitive sentences is more susceptible to prediction error than processing of the fronting alternation. When viewing a transitive event and listening for the description, listeners are likely to be strongly expecting the first noun they hear to be the agent of the sentence. Therefore, hearing the patient first is likely to lead to a strong prediction error and immediate revision of the expected structure. For fronting, on the contrary, participants may not build a strong expectation for the adverbial temporal phrase to be expressed first and thus may experience both less prediction error and less revision of syntactic structures. In other words, syntactic priming of passive and of fronted sentences could rely on prediction error to different degrees. Second, priming of one of the alternations may be more likely to rely on explicit memory processes than the other. For example, we hypothesized earlier that participants' higher attention or noticing rate for fronted sentences was associated with lower priming effects because participants deliberately decided to avoid producing this structure. On the contrary, their higher noticing rate for passives led to more priming in the condition without lexical overlap. Take together, this suggests that priming of passives relies more on implicit processes and priming of fronted sentences more on explicit processes. 


\section{Conclusion}

This study combined comparisons across different speaker groups and syntactic alternations to test predictions of an influential model of syntactic priming and language processing. Our findings were broadly compatible with previous research and the general predictions of the implicit error-based model of syntactic priming, however some of the more fine-tuned predictions were only partially supported. These findings add novel results regarding how individual differences in attention and motivation relate to within-group variation in priming and provide preliminary support for the expected between-group variation. It is possible that testing L2 speakers with more varied proficiency and motivational levels would yield further insight on this issue. Further investigations are also required to understand the nature of the mechanisms supporting syntactic priming in different groups of speakers and to examine whether, for instance, participants' voluntary decisions to avoid or re-use the target structures could be a factor that modulates priming effects across time and syntactic alternations. Moreover, the results demonstrate that the type of syntactic structure used to test such models can themselves influence the findings and therefore the interpretation. Overall, the present study highlights the necessity to run syntactic priming studies testing the same participants on several syntactic alternations as conclusions based on specific syntactic alternations may not apply to others.

\section{CRediT author statement}

Marion Coumel: Conceptualization, Methodology, Investigation, Data Curation, Validation, Formal Analysis, Writing- Original draft, Visualization; Ema Ushioda: Conceptualization, Methodology, Writing- Review \& Editing, Supervision, Funding acquisition; Katherine Messenger: Conceptualization, Methodology, Writing- Review \& Editing, Supervision, Project administration, Funding acquisition.

\section{Supplementary material}

The complete datasets and supplementary materials of the study are provided online in a dedicated repository on the Open Science Framework (https://osf.io/k2tay/?view_only=1849e74a6c4e4c7180667bda6f9ff530). 


\section{Acknowledgements}

This research was supported by a Leverhulme Trust Research Project grant [RPG-2017-082] to the last author. We thank Sophie M. Hardy for her helpful comments on a previous version of this article and in preparing our graphs.

\section{References}

Abrahams, L., Hartsuiker, R. J., De Fruyt, F., \& Bajo, M. T. (2019). Structural alignment and its prosocial effects in first and second languages. Acta Psychologica, 199. https://doi.org/10.1016/j.actpsy.2019.102906

Baayen, R. H., Davidson, D. J., \& Bates, D. M. (2008). Mixed-effects modelling with crossed random effects for subjects and items. Journal of Memory and Language, 59, 390412.

Barr, D. J., Levy, R., Scheepers, C., \& Tily, H. J. (2013). Random effects structure for confirmatory hypothesis testing: Keep it maximal. Journal of Memory and Language, 68(3), 255-278. https://dx.doi.org/10.1016/j.jml.2012.11.001.

Benati, A. (2016). Input manipulation, enhancement and processing: Theoretical views and empirical research. Studies in Second Language Learning and Teaching, 6(1), 65-88. https://doi.org/10.14746/ssllt.2016.6.1.4

Bernolet, S., Hartsuiker, R. J., \& Pickering, M. J. (2013). From language-specific to shared syntactic representations: The influence of second language proficiency on syntactic sharing in bilinguals. Cognition, 127(3), 287-306. doi:https://doi.org/10.1016/j.cognition.2013.02.005

Bock, J. K. (1986). Syntactic persistence in language production. Cognitive Psychology, 18(3), 355-387. https://doi.org/10.1016/0010-0285(86)90004-6

Bock, K., \& Griffin, Z. M. (2000). The persistence of structural priming: transient activation or implicit learning? Journal of Experimental Psychology: General, 129(2), 177-192.

Bock, K., Loebell, H., \& Morey, R. (1992). From conceptual roles to structural relations: bridging the syntactic cleft. Psychological Review, 99(1), 150-171.

Boekaerts, M. (2002). The On-Line Motivation Questionnaire: A self-report instrument to assess students' context sensitivity. In P.R. Pintrich \& M. L. Maehr (Eds.), New directions in measures and methods (Vol. 12, pp. 77-120). Oxford, England: Elsevier Science. 
Branigan, H. P., \& MacLean, J. F. (2016). What children learn from adults' utterances: An ephemeral lexical boost and persistent syntactic priming in adult-child dialogue. Journal of Memory and Language, 91, 141-157.

Branigan, H. P., \& Messenger, K. (2016). Consistent and cumulative effects of syntactic experience in children's sentence production: Evidence for error-based implicit learning. Cognition, 157, 250-256.

Branigan, H. P., Pickering, M. J., \& Cleland, A. A. (2000). Syntactic co-ordination in dialogue. Cognition, 75(2), B13-B25. https://doi.org/10.1016/S0010-0277(99)000815

Branigan, H. P., Pickering, M. J., \& McLean, J. F. (2005). Priming prepositional-phrase attachment during comprehension. Journal of Experimental Psychology-Learning Memory and Cognition, 31(3), 468-481. https://doi.org/10.1037/0278-7393.31.3.468.

Branigan, H. P., Pickering, M. J., McLean, J. F., \& Cleland, A. A. (2007). Syntactic alignment and participant role in dialogue. Cognition, 104(2), 163-197. https://doi.org/10.1016/j.cognition.2006.05.006

Brooks, P. J., \& Kempe, V. (2013). Individual differences in adult foreign language learning: the mediating effect of metalinguistic awareness. Memory \& Cognition, 41(2), 281296. https://doi.org/10.3758/s13421-012-0262-9.

Chang, F., Janciauskas, M., \& Fitz, H. (2012). Language adaptation and learning: Getting explicit about implicit learning. Language and Linguistics Compass, 6(5), 259-278.

Chang, F., Dell, G. S., \& Bock, K. (2006). Becoming syntactic. Psychological Review, 113(2), 234-272. https://doi.org/10.1037/0033-295x.113.2.234.

Cheng, L., Klinger, D., Fox, J., Doe, C., Jin, Y. and Wu, J. (2014). Motivation and test anxiety in test performance across three testing contexts: the CAEL, CET, and GEPT, Tesol Quarterly, 48(2), 300-330. https://dx.doi.org/10.1002/tesq.105.

Cocca, M., \& Cocca, A. (2019). Affective variables and motivation as predictors of proficiency in English as a foreign language. Journal on Efficiency and Responsibility in Education and Science, 12(3), 75-83. https://doi.org/10.7160/eriesj.2019.120302.

Crookes, G. S., \& Schmidt, W. R. (1991). Motivation: Reopening the research agenda. Language Learning, 4(4), 469-512.

Deci, E. L., \& Ryan, R. M. (1985). Intrinsic Motivation and Self-Determination in Human Behavior. New York: Plenum.

Dell, G. S., \& Chang, F. (2014). The P-chain: relating sentence production and its disorders to comprehension and acquisition. Philosophical Transactions of the Royal Society 
London B: Biolological Sciences, 369(1634), 20120394.

https://doi.org/10.1098/rstb.2012.0394.

Dörnyei, Z. (2002). The motivational basis of language learning tasks. In P. Robinson, (Ed.), Individual differences and instructed language learning (pp. 137-158). Amsterdam: John Benjamins.

Dörnyei, Z., with Taguchi, T. (2010). Questionnaires in second language research: Construction, administration, and processing (2nd ed.). New York: Routledge.

Dörnyei, Z., \& Kormos, J. (2000). The role of individual and social variables in oral task performance. Language Teaching Research, 4(3), 275-300. https://doi.org/10.1177/136216880000400305.

Dörnyei, Z. \& Skehan, P. (2003). Individual differences in second language learning. In C.J. Doughty \& M. Long (Eds.), The handbook of second language acquisition (pp. 589630). Oxford: Blackwell.

Eccles, J. S. (1993). School and family effects on the ontogeny of children's interests, selfperceptions, and activity choices. In J. Jacobs (Ed.), Nebraska Symposium on Motivation, 1992: Developmental perspectives on motivation (pp.145-208). Lincoln: University of Nebraska Press.

Favier, S., Wright, A., Meyer, A. \& Huettig, F. (2019). Proficiency modulates between- but not within-language structural priming. Journal of Cultural Cognitive Science, 3, $105-$ 124. https://doi.org/10.1007/s41809-019-00029-1.

Ferreira, V. S., \& Bock, K. (2006). The functions of structural priming. Language and Cognitive Processes, 21, 1011-1029.

Flett, S. (2006). A comparison of syntactic representation and processing in first and second language production [Unpublished doctoral dissertation]. University of Edinburgh. Gardner, R. C. (1985). Social psychology and second language learning: the role of attitudes and motivation. London: Edward Arnold.

Hardy, S. M., Messenger, K., \& Maylor, E. A. (2017). Aging and syntactic representations: Evidence of preserved syntactic priming and lexical boost. Psychology and Aging, 32(6), 588-596. https://doi.org/10.1037/pag0000180.

Hartsuiker, R. J., \& Bernolet, S. (2017). The development of shared syntax in second language learning. Bilingualism: Language and Cognition, 20(2), 219-234. https://doi.org/10.1017/S1366728915000164.

Hartsuiker, R. J., Bernolet, S., Schoonbaert, S., Speybroeck, S., \& Vanderelst, D. (2008). Syntactic priming persists while the lexical boost decays: Evidence from written and 
spoken dialogue. Journal of Memory and Language, 58(2), 214-238. https://doi.org/10.1016/j.jml.2007.07.003.

Hartsuiker, R. J., \& Kolk, H. H. J. (1998). Syntactic persistence in Dutch. Language and Speech, 41, 143-184. https://doi.org/10.1177/002383099804100202.

Hartsuiker, R. J., Pickering, M. J., \& Veltkamp, E. (2004). Is syntax separate or shared between languages? Cross-linguistic syntactic priming in Spanish-English bilinguals. Psychological Science, 15(6), 409-414. https://doi.org/10.1111/j.09567976.2004.00693.x.

Hartsuiker, R. J., \& Westenberg, C. (2000). Word order priming in written and spoken sentence production. Cognition, 75(2), B27-39.

Indrarathne, B., \& Kormos, J. (2017). Attentional processing of input in explicit and implicit conditions: An Eye-Tracking Study. Studies in Second Language Acquisition, 39(3), 401-430. https://doi.org/10.1017/S027226311600019X

Ivanova, I., Horton, W. S., Swets, B., Kleinman, D., \& Ferreira, V. S. (2020). Structural alignment in dialogue and monologue (and what attention may have to do with it). Journal of Memory and Language, 110. https://doi.org/10.1016/j.jml.2019.104052.

Jackson, C. N. (2018). Second language structural priming: A critical review and directions for future research. Second Language Research, 34(4), 539-552. https://doi.org/10.1177/0267658317746207.

Jackson, C. N., \& Hopp, H. (2020). Prediction error and implicit learning in L1 and L2 syntactic priming. International Journal of Bilingualism. https://doi.org/10.1177/1367006920902851.

Jackson, C.N., \& Ruf, H. (2017a). The priming of word order in second language German. Applied Psycholinguistics, 38, 315-345. https://doi.org/10.1017/SO142716416000205.

Jackson, C.N., \& Ruf, H. (2017b). The importance of prime repetition among intermediatelevel second language learners. Studies in Second Language Acquisition, 40(3), 677692. https://doi.org/10.1017/S0272263117000365.

Jaeger, T. F. (2008). Categorical data analysis: Away from ANOVAs (transformation or not) and towards logit mixed models. Journal of Memory and Language, 59, 434-446.

Jaeger, T. F., \& Snider, N. E. (2013). Alignment as a consequence of expectation adaptation: syntactic priming is affected by the prime's prediction error given both prior and recent experience. Cognition, 127(1), 57-83. https://doi.org/10.1016/j.cognition.2012.10.013. 
Kaan, E., \& Chun, E. (2017). Priming and adaptation in native speakers and second-language learners. Bilingualism: Language and Cognition, 1-15. https://doi.org/10.1017/S1366728916001231.

Kang, D.H. (2001). Foreign language learning motivation revisited: A longitudinal study. Foreign Languages Education, 8(2), 223-244.

Kaschak, M., P., Kutta, T., J., \& Jones, J. L. (2011). Structural priming as implicit learning: Cumulative priming effects and individual differences. Psychonomic Bulletin and Review, 18, 1133-1139.

Kaschak, M., P., Kutta, T., J., \& Schatschneider, C. (2011). Long-term cumulative priming persists for (at least) one week. Memory \& Cognition, 39(3), 381-8. https://doi.org/10.3758/s13421-010-0042-3.

Kerz, E., Wiechmann, D. \& Riedel, F. B. (2017). Implicit learning in the crowd: Investigating the role of awareness in the acquisition of L2 knowledge. Studies in Second Language Acquisition, 39(4), 711-734. https://doi.org/10.1017/S027226311700002X.

Kidd, E. (2012). Individual differences in syntactic priming in language acquisition. Applied Psycholinguistics, 33, 393-418.

Kim, Y., \& McDonough, K. (2008). Learners' production of passives during syntactic priming activities. Applied Linguistics, 29, 149-154.

Kormos, J. D., Dörnyei, Z. (2004). The interaction of linguistic and motivational variables in second language task performance. Zeitschrift für Interkulturellen Fremdsprachunterricht., 9(2), 1-19.

Lemhofer, K., \& Broersma, M. (2012). Introducing LexTALE: A quick and valid Lexical Test for Advanced Learners of English. Behavior Research Methods, 44(2), 325-343. https://doi.org/10.3758/s13428-011-0146-0.

Mahowald, K., James, A., Futrell, R., \& Gibson, E. (2016). A meta-analysis of syntactic priming in language production. Journal of Memory and Language, 91, 5-27. https://doi.org/10.1016/j.jml.2016.03.009.

Malhotra, G., Pickering, M. J., Branigan, H. P., \& Bednar, J. A. (2008). On the persistence of Structural priming: mechanisms of decay and influence of word-forms. In Proceedings of the 30th Annual Conference of the Cognitive Science Society (pp. 657662). Cognitive Science Society.

Marian, V., Blumenfeld, H. K., \& Kaushanskaya, M. (2007). Language Experience and Proficiency Questionnaire (LEAP-Q). Journal of Speech Language and Hearing Research, 50(4), 940-967. 
Masgoret, A. M., \& Gardner, R. C. (2003). Attitudes, motivation, and second language learning: A meta-analysis of studies conducted by Gardner and associates. Language Learning, 53(1), 123-163. https://doi.org/10.1111/1467-9922.00212.

McDonough, K. (2011). Eliciting wh-questions through collaborative syntactic priming activities during peer interaction. In P. Trofimovich \& K. McDonough (Eds.), Applying priming methods to L2 learning, teaching, and research: Insights from psycholinguistics (pp. 131-151). Amsterdam, The Netherlands: John Benjamins.

McDonough, K., \& Chaikitmongol, W. (2010). Collaborative Syntactic Priming Activities and EFL Learners' Production of Wh-Questions. Canadian Modern Language Review-Revue Canadienne Des Langues Vivantes, 66(6), 817-842. https://doi.org/10.3138/cmlr.66.6.817.

McDonough, K., \& Fulga, A. (2015). The Detection and Primed Production of Novel Constructions. Language Learning, 65(2), 326-357. https://doi.org/10.1111/lang.12103.

McDonough, K., \& Mackey, A. (2008). Syntactic priming and ESL question development. Studies in Second Language Acquisition, 30(1), 31-47. https://doi.org/10.1017/s0272263108080029.

Nitschke, S., Serratrice, L., \& Kidd, E. (2014). The effect of linguistic nativeness on structural priming in comprehension. Language Cognition and Neuroscience, 29(5), 525-542. https://doi.org/10.1080/01690965.2013.766355.

Noels, K. A., Clément, R., \& Pelletier, L. G. (2001). Intrinsic, extrinsic, and integrative orientations of French Canadian learners of English. Canadian Modern Language Review-Revue Canadienne Des Langues Vivantes, 57(3), 424-442. https://doi.org/10.3138/cmlr.57.3.424.

Noels, K. A., Pelletier, L. G., Clément, R., \& Vallerand, R. J. (2000). Why are you learning a second language? Motivational orientations and self-determination theory. Language Learning, 50, 57-85.

Pickering, M. J., \& Branigan, H. P. (1998). The Representation of Verbs: Evidence from Syntactic Priming in Language Production. Journal of Memory and Language, 39(4), 633-651. https://doi.org/10.1006/jmla.1998.2592.

Pickering, M. J., \& Ferreira, V. S. (2008). Structural Priming: A Critical Review. Psychological bulletin, 134(3), 427-459. https://doi.org/10.1037/0033$\underline{2909.134 .3 .427 .}$ 
Pickering, M. J., \& Garrod, S. (2004). Toward a mechanistic psychology of dialogue. Behavioral and Brain Sciences, 27, 169-225.

Reitter, D., Keller, F., \& Moore, J. D. (2011). A Computational Cognitive Model of Syntactic Priming. Cognitive Science, 35(4), 587-637. https://doi.org/10.1111/j.15516709.2010.01165.x.

Reitter, D., \& Moore, J. D. (2014). Alignment and task success in spoken dialogue. Journal of Memory and Language, 76, 29-46. https://doi.org/10.1016/j.jml.2014.05.008

Robinson, P., Mackey, A., Gass, S. \& Schmidt, R. (2012). Attention and awareness in second language acquisition. In S. Gass \& A. Mackey (Eds.), The Routledge handbook of second language acquisition (pp. 247-267). New York: Routledge.

Ruf, H. T. (2011). An investigation of syntactic priming among German speakers at varying proficiency levels [Unpublished doctoral dissertation]. University of WisconsinMadison.

Saito, K., Dewaele, J. M., \& Hanzawa, K. (2017). A Longitudinal Investigation of the Relationship between Motivation and Late Second Language Speech Learning in Classroom Settings. Language and Speech, 60(4), 614-632. https://doi.org/10.1177/0023830916687793.

Savage, C., Lieven, E., Theakston, A., \& Tomasello, M. (2006). Structural priming as implicit learning in language acquisition: the persistence of lexical and structural priming in 4-year-olds. Language Learning and Development. http://dx.doi.org/10.1207/s154733411ld0201_2.

Schmidt, R. W. (1990). The Role of Consciousness in Second Language Learning1. Applied Linguistics, 11(2), 129-158. https://doi.org/10.1093/applin/11.2.129.

Schoot, L., Hagoort, P., \& Segaert, K. (2019) Stronger Syntactic Alignment in the Presence of an Interlocutor. Frontiers in Psychology, 10, 685. https://doi.org/10.3389/fpsyg.2019.00685.

Serafini, E. J. (2013). Cognitive and Psychosocial factors in the long-term development of implicit and explicit second language knowledge in adult learners of Spanish at increasing proficiency [Unpublished doctoral dissertation]. Georgetown University.

Shin, J. A., \& Christianson, K. (2012). Structural priming and second language learning. Language Learning, 62(3), 931-964.

Takahashi, S. (2005). Pragmalinguistic awareness: Is it related to motivation and proficiency? Applied Linguistics, 26(1), 90-120. https://doi.org/10.1093/applin/amh040. 
Ushioda, E. (2016). Language learning motivation through a small lens: A research agenda. Language Teaching, 49(4), 564-577. https://doi.org/10.1017/S0261444816000173.

Ushioda, E. D., \& Dörnyei, Z. (2012). Motivation. In S. Gass \& A. Mackey (Eds.), The Routledge handbook of second language acquisition (pp. 396-409). Abingdon: Routledge.

Weatherholtz, K., Campbell-Kibler, K., \& Jaeger, T., F. (2014). Socially-mediated syntactic alignment. Language Variation and Change, 26, 387-420. https://doi.org/10.1017/S0954394514000155.

Wen, X. (1997). Motivation and language learning with students of Chinese. Foreign Language Annals, 30(2), 235-251.

Wigfield, A., \& Eccles, J. S. (2000). Expectancy-value theory of achievement motivation. Contemporary Educational Psychology, 25(1), 68-81. https://doi.org/10.1006/ceps.1999.1015. 
Table 1. Overview of response frequencies in Study 1. Frequency of target responses by group, overlap condition and experiment phase.

\begin{tabular}{|c|c|c|c|c|c|}
\hline \multirow[b]{2}{*}{ Group } & \multirow[b]{2}{*}{ Condition } & \multirow[b]{2}{*}{ Phase (prime) } & \multicolumn{3}{|c|}{ Response } \\
\hline & & & Non-fronted & Fronted & Other \\
\hline \multirow[t]{8}{*}{ L2 speakers } & No overlap & Pre-test & 187 & 75 & 12 \\
\hline & & Priming (non-fronted) & 324 & 215 & 10 \\
\hline & & Priming (fronted) & 251 & 298 & 9 \\
\hline & & Post-test & 132 & 137 & 7 \\
\hline & Overlap & Pre-test & 203 & 80 & 11 \\
\hline & & Priming (non-fronted) & 458 & 120 & 11 \\
\hline & & Priming (fronted) & 172 & 407 & 5 \\
\hline & & Post-test & 150 & 139 & 4 \\
\hline \multirow[t]{8}{*}{ L1 speakers } & No overlap & Pre-test & 180 & 83 & 7 \\
\hline & & Priming (non-fronted) & 274 & 258 & 6 \\
\hline & & Priming (fronted) & 206 & 328 & 8 \\
\hline & & Post-test & 129 & 136 & 3 \\
\hline & Overlap & Pre-test & 200 & 83 & 15 \\
\hline & & Priming (non-fronted) & 405 & 184 & 9 \\
\hline & & Priming (fronted) & 227 & 368 & 7 \\
\hline & & Post-test & 154 & 139 & 3 \\
\hline
\end{tabular}

Table 2. Individual differences descriptive statistics of Study 1. Mean scores (SD) and ranges (in italics) for each measure by group and overlap condition.

\begin{tabular}{llcccc}
\hline \multirow{2}{*}{ Measure } & & \multicolumn{3}{c}{ L2 } & \multicolumn{2}{c}{ L1 } \\
\cline { 3 - 6 } Attention/ & Syntax & No overlap & Overlap & No overlap & Overlap \\
awareness & & $5.22(1.16)$ & $5.10(1.37)$ & $5.11(1.37)$ & $5.26(1.32)$ \\
& \multirow{2}{*}{ Stimuli and Task } & $5.47(0.96)$ & $5.68(0.80)$ & $5.2(1.11)$ & $5.18(1.22)$ \\
& & $3.5-7$ & $4-7$ & $3-7$ & $1.5-7$ \\
\hline Motivation & French learning & $5.39(0.69)$ & $5.33(0.76)$ & - & - \\
& motivation (PC1) & $3.35-6.65$ & $2.53-6.65$ & & - \\
& Task-specific & $4.84(0.59)$ & $5.08(0.69)$ & - & - \\
& motivation (PC2) & $3.56-6.22$ & $3.44-6.22$ & & - \\
\hline Proficiency & & $6.5(2.0)$ & $6.13(1.82)$ & - & \\
& & $1.5-9$ & $1.5-9$ & & \\
\end{tabular}


7 was the maximum score for the attention and motivation scales; 2 for the noticing score; 10 for the proficiency score.

Table 3. Noticing statistics of Study 1. Raw number (percentage) of participants scoring 0, 1 and 2 per group per condition

\begin{tabular}{llcccc}
\hline \multirow{2}{*}{ Measure } & & \multicolumn{2}{c}{ L2 } \\
\cline { 3 - 6 } & & No overlap & Overlap & No overlap & Overlap \\
\hline Noticing & 0 & $28(60.9 \%)$ & $26(53.1 \%)$ & $30(66.7 \%)$ & $29(58 \%)$ \\
& 1 & $10(21.7 \%)$ & $5(10.2 \%)$ & $2(4.4 . \%)$ & $5(10 \%)$ \\
& 2 & $8(17.4 \%)$ & $18(36.7 \%)$ & $13(28.9 \%)$ & $16(32 \%)$ \\
\hline
\end{tabular}

Table 4. Model for immediate priming in Study 1. Summary of the best model for immediate priming of fronted sentences in L1 vs. L2 speakers.

\begin{tabular}{lllll}
\hline Fixed effects & Estimate & Standard Error & Z-value & $\boldsymbol{p}$-value \\
\hline Prime Syntax & 1.76 & .12 & 14.84 & $<.001$ \\
Group & -.25 & .27 & -.93 & .35 \\
Overlap & -.37 & .28 & -1.31 & .19 \\
Side & -.46 & .14 & -3.30 & .001 \\
Prime Syntax x Group & .58 & .23 & 2.56 &. $\mathbf{0 1}$ \\
Prime Syntax x Overlap & 1.56 & .23 & 6.79 & $<.001$ \\
Group x Overlap & .47 & .53 & .89 & .37 \\
Prime Syntax x Side & -.11 & .16 & -.70 & .48 \\
Group x Side & .37 & .16 & 2.30 & .02 \\
Overlap x Side & .39 & .24 & 1.64 & .10 \\
Prime Syntax x Group x Overlap & .95 & .46 & 2.08 & .04 \\
Prime Syntax x Group x Side & -.18 & .32 & -.57 & .57 \\
Prime Syntax x Overlap x Side & -.08 & .32 & -.26 & .80 \\
Group x Overlap x Side & -.45 & .32 & -1.40 & .16 \\
Prime Syntax x Group x Overlap x Side & -.85 & .64 & -1.33 & .18 \\
\hline
\end{tabular}

Table 5. Model for long-term priming in Study 1. Summary of the model without random slopes and without interactions for long-term priming of fronted sentences in L1 vs. L2 speakers.

\begin{tabular}{|c|c|c|c|c|}
\hline Fixed effects & Estimate & Standard Error & z-value & $p$-value \\
\hline Section & 1.59 & .39 & 4.06 & 6.001 \\
\hline
\end{tabular}




\begin{tabular}{lllll} 
Speaker Group & -.05 & .33 & -.15 & .88 \\
Overlap & -.28 & .33 & -.83 & .41 \\
Side & -.59 & .31 & -1.87 & .06 \\
\hline
\end{tabular}

Table 6. Overview of response frequencies in Study 2. Frequency of target responses by group, overlap condition and experiment phase.

\begin{tabular}{|c|c|c|c|c|c|}
\hline \multirow[b]{2}{*}{ Group } & \multirow[b]{2}{*}{ Condition } & \multirow[b]{2}{*}{ Phase (prime) } & \multicolumn{3}{|c|}{ Response } \\
\hline & & & Active & Passive & Other \\
\hline \multirow[t]{8}{*}{ L2 speakers } & No overlap & Pre-test & 211 & 0 & 41 \\
\hline & & Priming (active) & 395 & 50 & 62 \\
\hline & & Priming (passive) & 357 & 87 & 56 \\
\hline & & Post-test & 184 & 43 & 25 \\
\hline & Overlap & Pre-test & 240 & 1 & 53 \\
\hline & & Priming (active) & 481 & 40 & 69 \\
\hline & & Priming (passive) & 191 & 280 & 115 \\
\hline & & Post-test & 172 & 90 & 32 \\
\hline \multirow[t]{8}{*}{ L1 speakers } & No overlap & Pre-test & 229 & 2 & 38 \\
\hline & & Priming (active) & 451 & 41 & 48 \\
\hline & & Priming (passive) & 433 & 51 & 55 \\
\hline & & Post-test & 222 & 21 & 27 \\
\hline & Overlap & Pre-test & 246 & 1 & 53 \\
\hline & & Priming (active) & 482 & 59 & 58 \\
\hline & & Priming (passive) & 383 & 169 & 48 \\
\hline & & Post-test & 249 & 39 & 12 \\
\hline
\end{tabular}

Table 7. Individual differences descriptive statistics of Study 2. Mean scores (SD) and ranges (in italics) for each measure by group and overlap condition.

\begin{tabular}{llcccc}
\hline \multirow{2}{*}{ Measure } & & \multicolumn{2}{c}{ L2 } \\
\cline { 3 - 6 } & & No overlap & Overlap & No overlap & Overlap \\
\hline Attention/ & Syntax & $5.26(1.20)$ & $5.10(1.37)$ & $5.13(1.37)$ & $5.26(1.32)$ \\
awareness & & $2-7$ & $1-7$ & $1-7$ & $2-7$ \\
& \multirow{2}{*}{ Stimuli and Task } & $5.49(0.95)$ & $5.68(0.80)$ & $5.2(1.11)$ & $5.18(1.22)$ \\
& & $3.5-7$ & $4-7$ & $3-7$ & $1.5-7$ \\
\hline Motivation & French learning & $5.42(0.70)$ & $5.33(0.76)$ & - & - \\
& motivation (PC1) & $3.35-6.65$ & $2.53-6.65$ & &
\end{tabular}




\begin{tabular}{llcccc} 
& Task-specific & $4.85(0.57)$ & $5.08(0.69)$ & - & - \\
& motivation (PC2) & $3.67-6.22$ & $3.44-622$ & & - \\
\hline Proficiency & & $6.53(2.04)$ & $6.13(1.80)$ & - & \\
& & $1.5-9$ & $1.5-9$ & & \\
& & &
\end{tabular}

7 was the maximum score for the attention and motivation scales; 2 for the noticing score; 10 for the proficiency score.

Table 8. Noticing statistics of Study 2. Raw number (percentage) of participants scoring 0, 1 and 2 per group per condition

\begin{tabular}{lccccc}
\hline \multirow{2}{*}{ Measure } & & \multicolumn{2}{c}{ L2 } & \multicolumn{2}{c}{ L1 } \\
\cline { 3 - 6 } & & No overlap & Overlap & No overlap & Overlap \\
\hline Noticing & 0 & $23(54.8 \%)$ & $22(44.9 \%)$ & $19(42.2 \%)$ & $14(28 \%)$ \\
& 1 & $17(40.5 \%)$ & $6(12.2 \%)$ & $24(53.3 \%)$ & $3(6 \%)$ \\
& 2 & $2(4.8 \%)$ & $21(42.9 \%)$ & $2(4.4 \%)$ & $33(66 \%)$ \\
\hline
\end{tabular}

Table 9. Model for immediate priming in Study 2. Summary of the best model for immediate priming of passive sentences in L1 vs. L2 speakers.

\begin{tabular}{lllll}
\hline \multicolumn{1}{c}{ Fixed effects } & Estimate & Standard Error & z-value & \multicolumn{1}{c}{$\boldsymbol{p}$-value } \\
\hline Prime syntax & 1.91 & .27 & 7.16 & $<.001$ \\
Group & .64 & .29 & 2.20 & $\mathbf{. 0 3}$ \\
Overlap & 1.14 & .30 & 3.83 & $<.001$ \\
Prime Syntax x Group & 1.22 & .37 & 3.31 & $<.001$ \\
Prime Syntax x Overlap & 2.45 & .38 & 6.44 & $<.001$ \\
Group x Overlap & -.25 & .58 & -.43 & .67 \\
Prime Syntax x Group x Overlap & 1.69 & .74 & 2.29 & $\mathbf{. 0 2}$ \\
\hline
\end{tabular}

Table 10. Model for long-term priming in Study 2. Summary of the model without random slopes and without interactions for long-term priming of passive sentences in L1 vs. L2 speakers.

\begin{tabular}{|c|c|c|c|c|}
\hline Fixed effects & Estimate & Standard Error & z-value & $p$-value \\
\hline Section & 4.38 & .67 & 6.52 & $<.001$ \\
\hline Group & 1.40 & .33 & 4.27 & $<.001$ \\
\hline Overlap & .92 & .33 & 2.83 & .005 \\
\hline
\end{tabular}


Table 11. Across-structure comparison. Pearson correlations across structures for magnitude of immediate priming and long-term priming effects per speaker group and lexical overlap condition.

\begin{tabular}{llllcccc}
\hline & Priming & Overlap & N & Passive & Fronted & r & P value \\
& type & & & M (SD) & M (SD) & & \\
\hline L2 & Immediate & Overlap & 49 & $.47(.36)$ & $.49(.28)$ & .38 & .007 \\
speakers & priming & No overlap & 42 & $.07(.25)$ & $.15(.19)$ & .22 & .15 \\
& Long-term & Overlap & 49 & $.32(.29)$ & $.19(.41)$ & .09 & .52 \\
& priming & No overlap & 42 & $.19(.24)$ & $.20(.40)$ & .23 & .15 \\
\hline L1 & Immediate & Overlap & 50 & $.19(.24)$ & $.31(.29)$ & .48 & $<.001$ \\
speakers & priming & No overlap & 45 & $-.03(.19)$ & $.13(.17)$ & .13 & .40 \\
& Long-term & Overlap & 50 & $.13(.21)$ & $.17(.29)$ & .35 & .01 \\
& priming & No overlap & 45 & $.09(.20)$ & $.20(.40)$ & -.04 & .81 \\
\hline
\end{tabular}




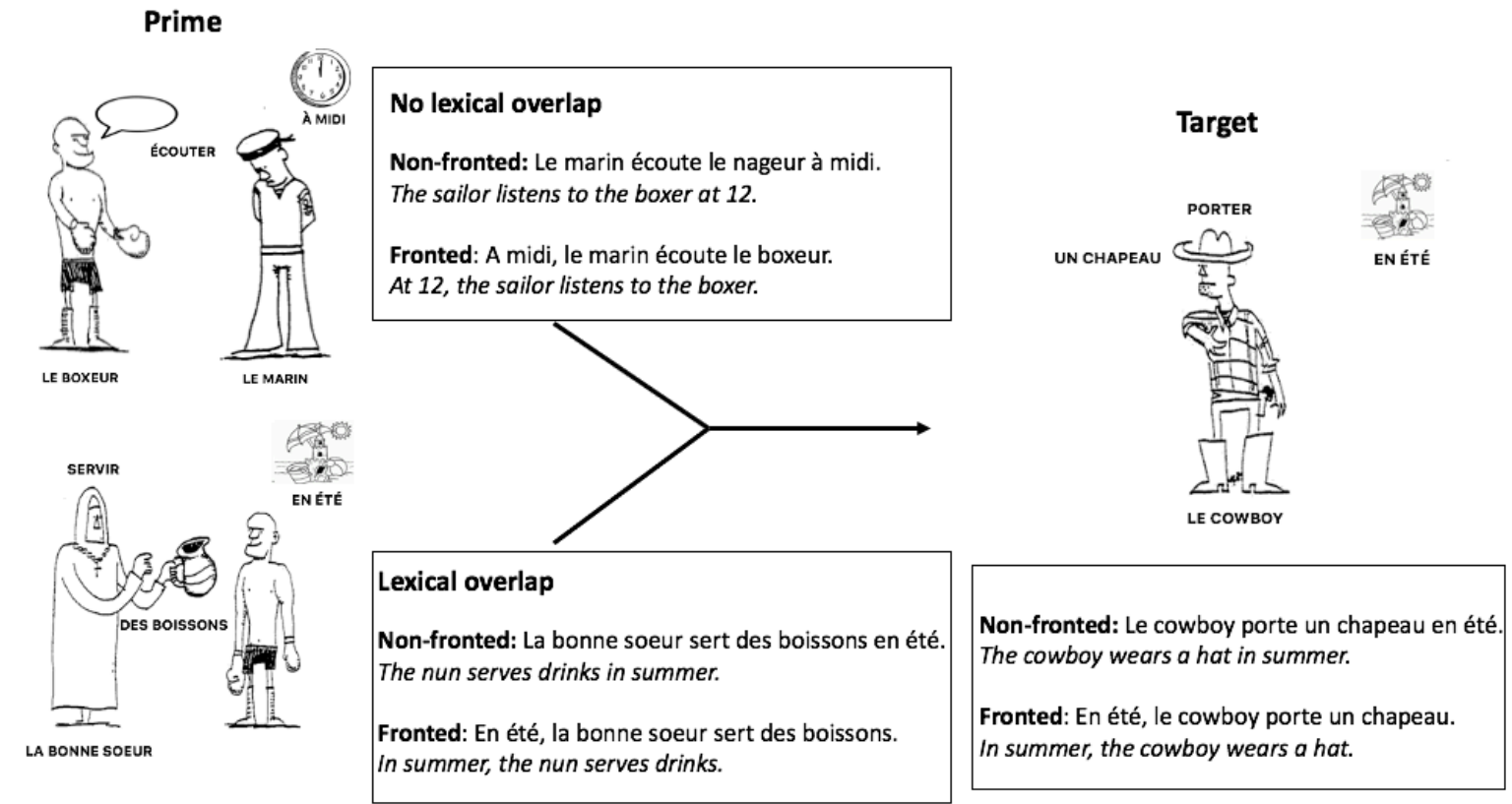

Figure 1. Stimuli of Study 1. Example of fronted/ non-fronted TP prime and target stimuli.

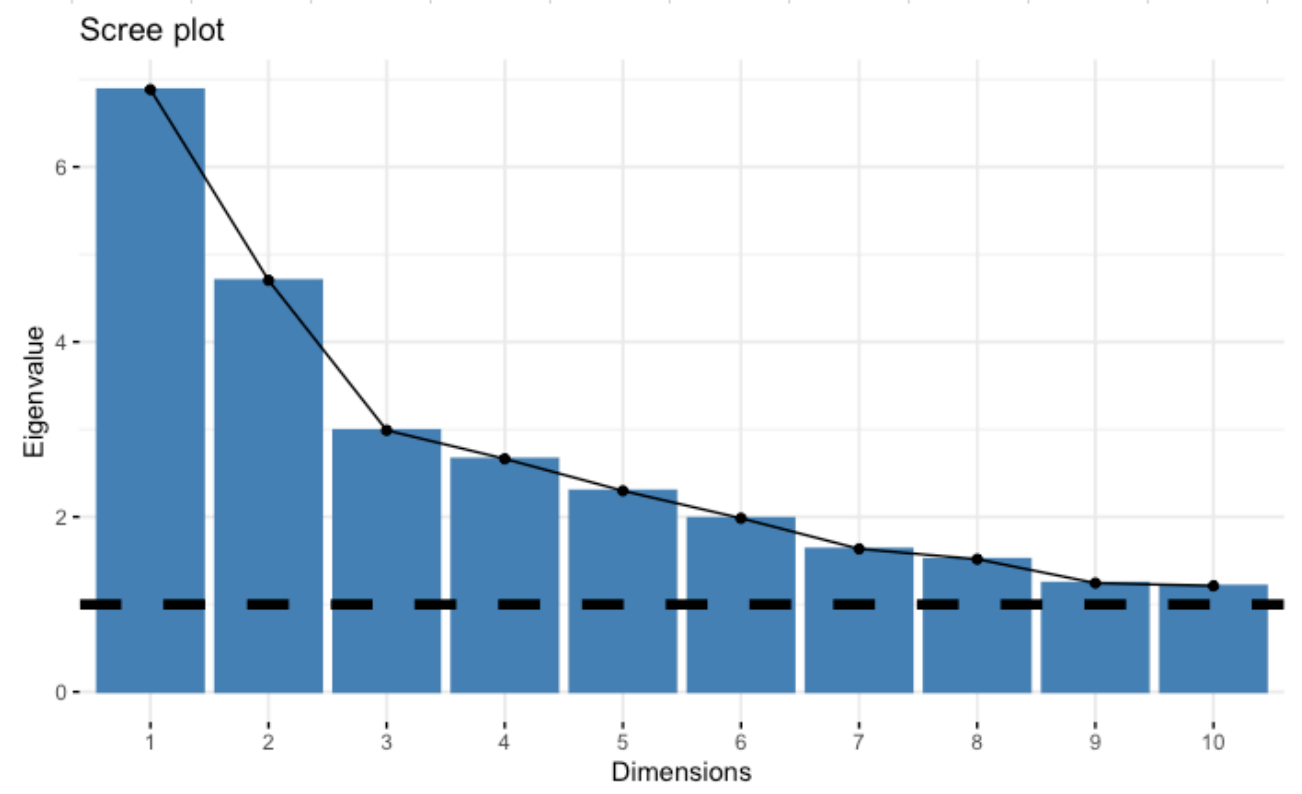

Figure 2. Screeplot. This depicts the eigenvalues of each PCs defined by the PCA analysis. 


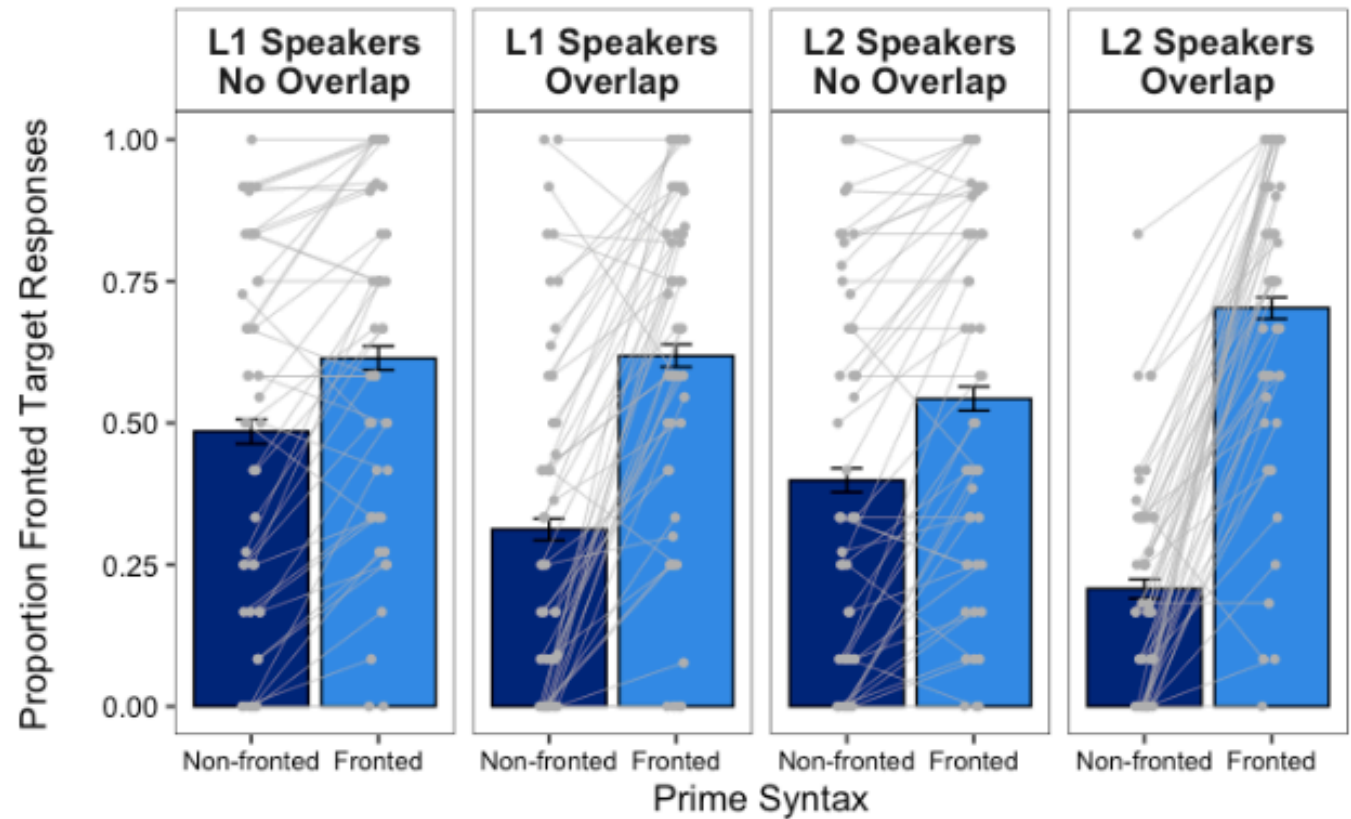

Figure 3. Fronted responses in the priming phase. Mean proportion of fronted responses out of all fronted and non-fronted responses by prime syntax, overlap and group condition in the immediate priming phase. Error bars indicate the standard error of the mean, grey dots indicate individual data points and grey lines individual priming effects.

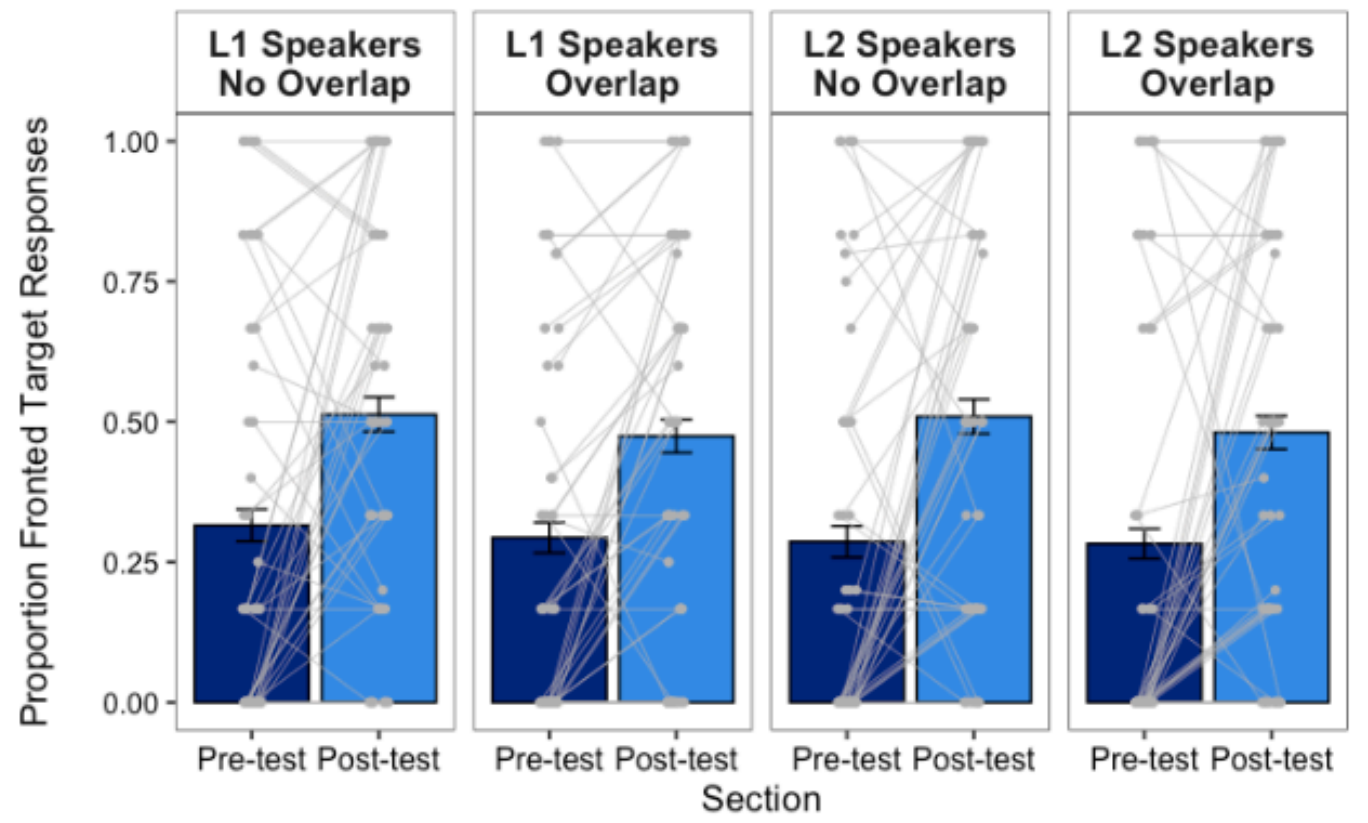

Figure 4. Fronted responses in the pre- and post-tests. Mean proportion of fronted descriptions in the pre- and post-tests out of all fronted and non-fronted descriptions by section, overlap and group condition. Error bars indicate the standard error of the mean, grey dots indicate individual data points and grey lines individual priming effects. 
a) L2 speakers

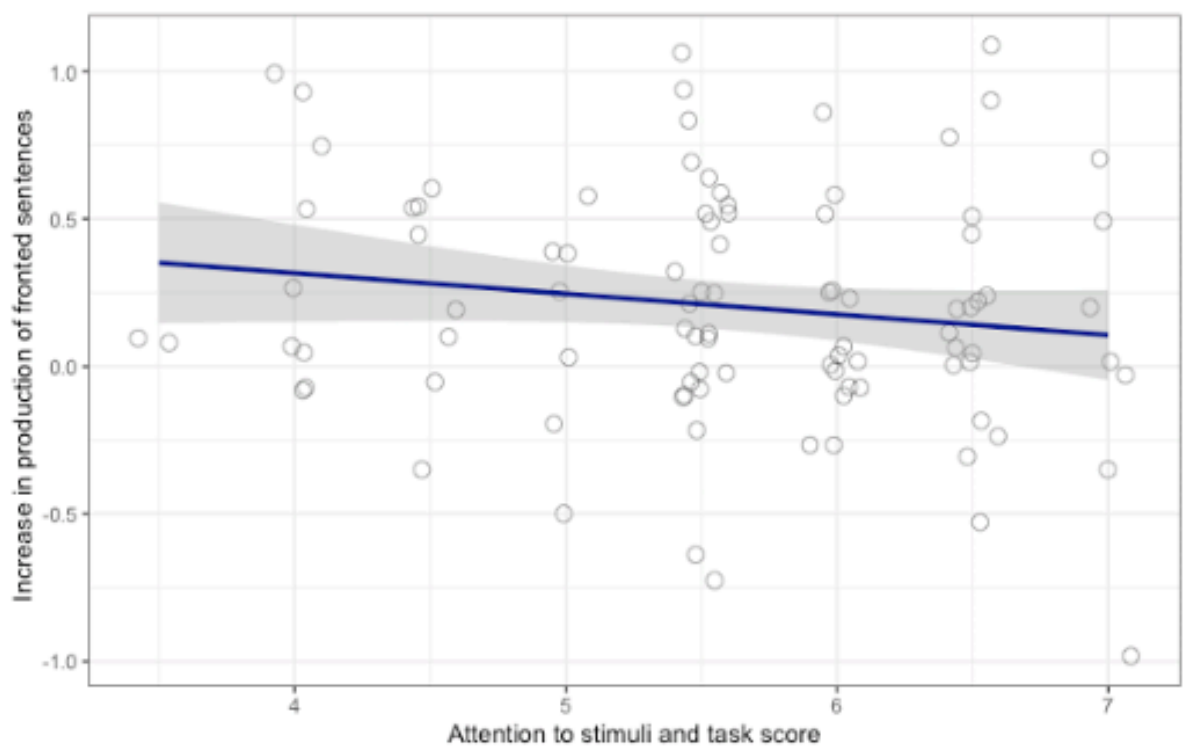

b) L1 speakers

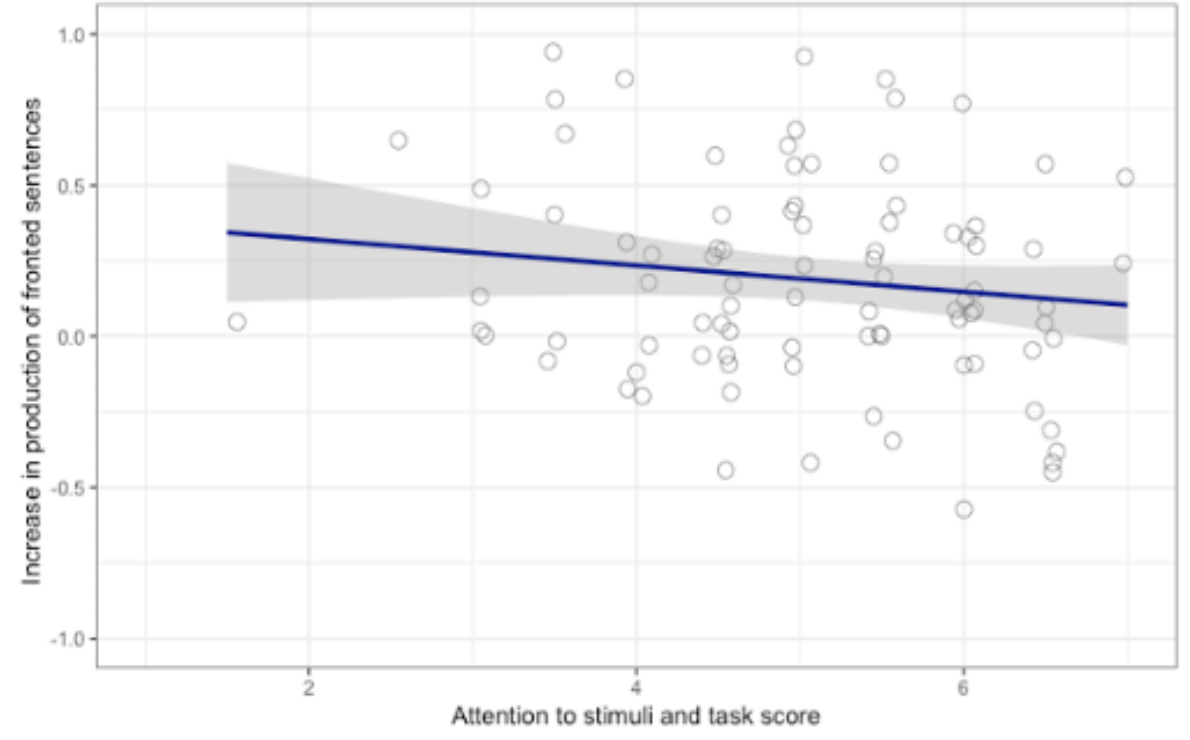

Figure 5. Attention to stimuli and task in Study 1. Increase in production of fronted sentences between the pre- and post-test as a function of attention to stimuli and task in L2 (a) and L1 (b) speakers. The grey area represents the confidence interval. 


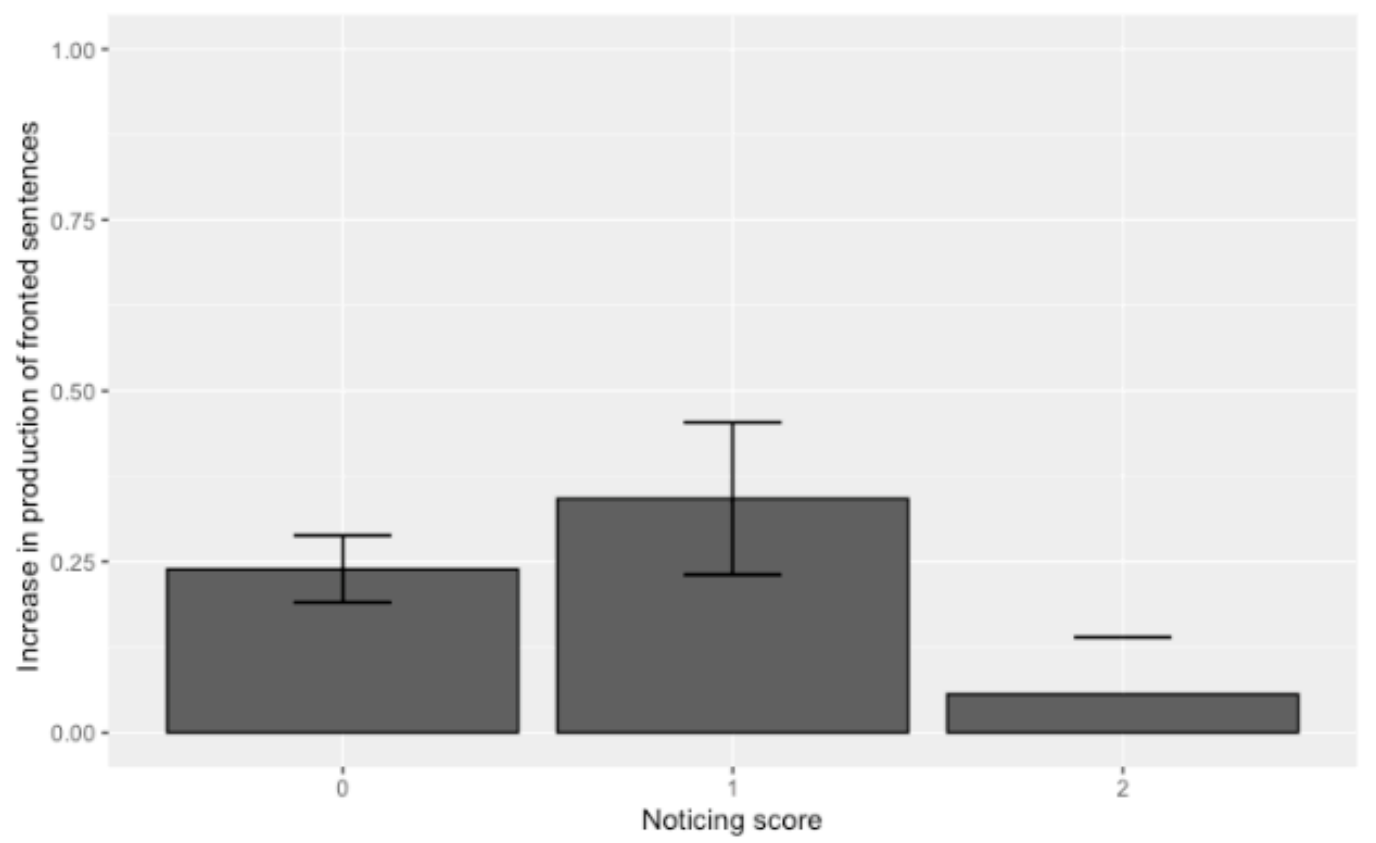

Figure 6. Noticing in Study 1. Increase in production of fronted sentences between the preand post-test as a function of Noticing in the L2 speakers. The bars represent the standard error. $0=$ not noticing the target structure at all, $1=$ noticing it (Noticing 1 ) and $2=$ noticing it and understanding it (Noticing 2).

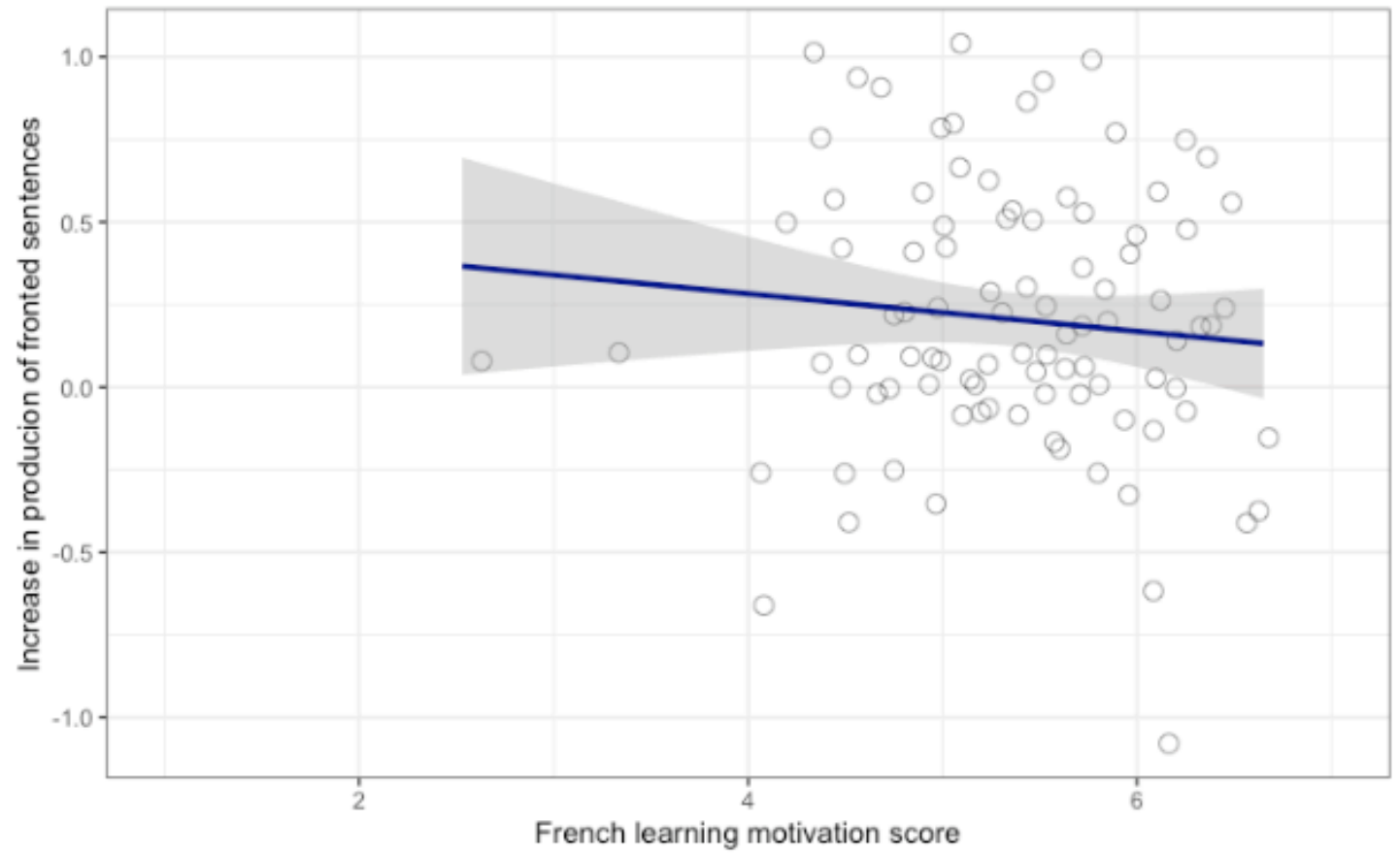

Figure 7. French learning motivation in Study 1. Increase in production of fronted sentences between the pre- and post-test as a function of French learning motivation. The grey area represents the confidence interval. 


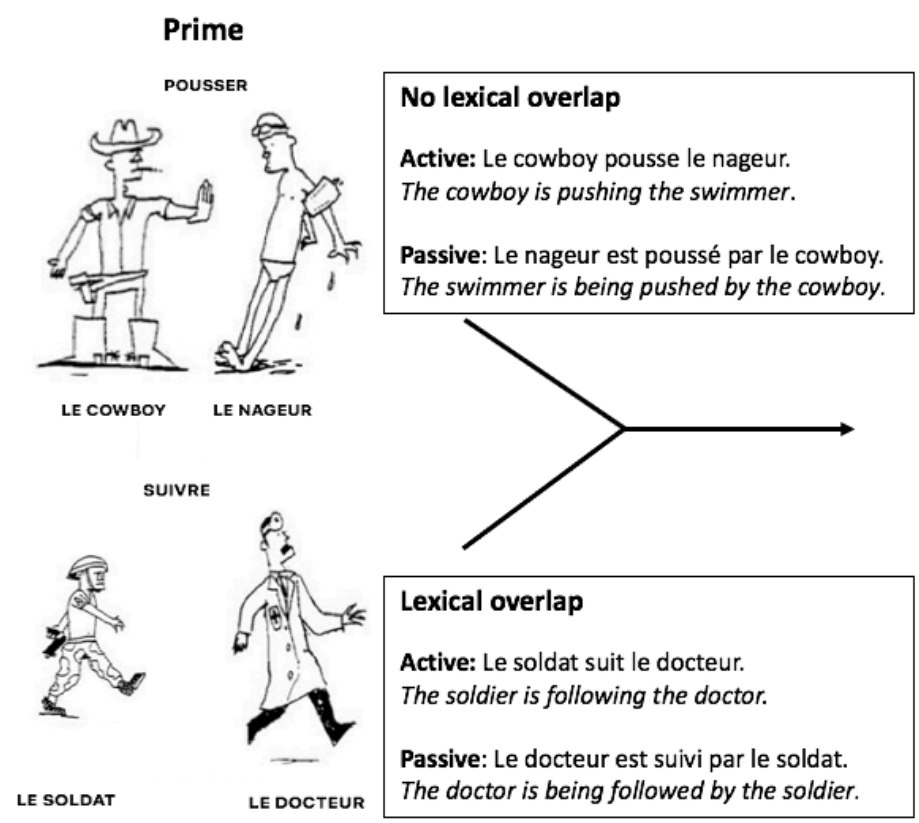

Target

SUIVRE
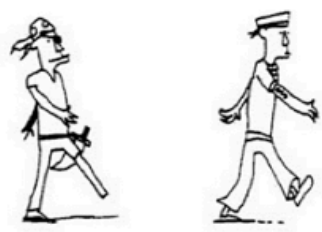

LE PIRATE

LEMARIN

Active: Le pirate suit le marin.

The pirate is following the sailor.

Passive: Le marin est suivi par le pirate.

The sailor is being followed by the pirate.

Figure 8. Sitmuli of Study 2. Example of active/passive prime and target stimuli.

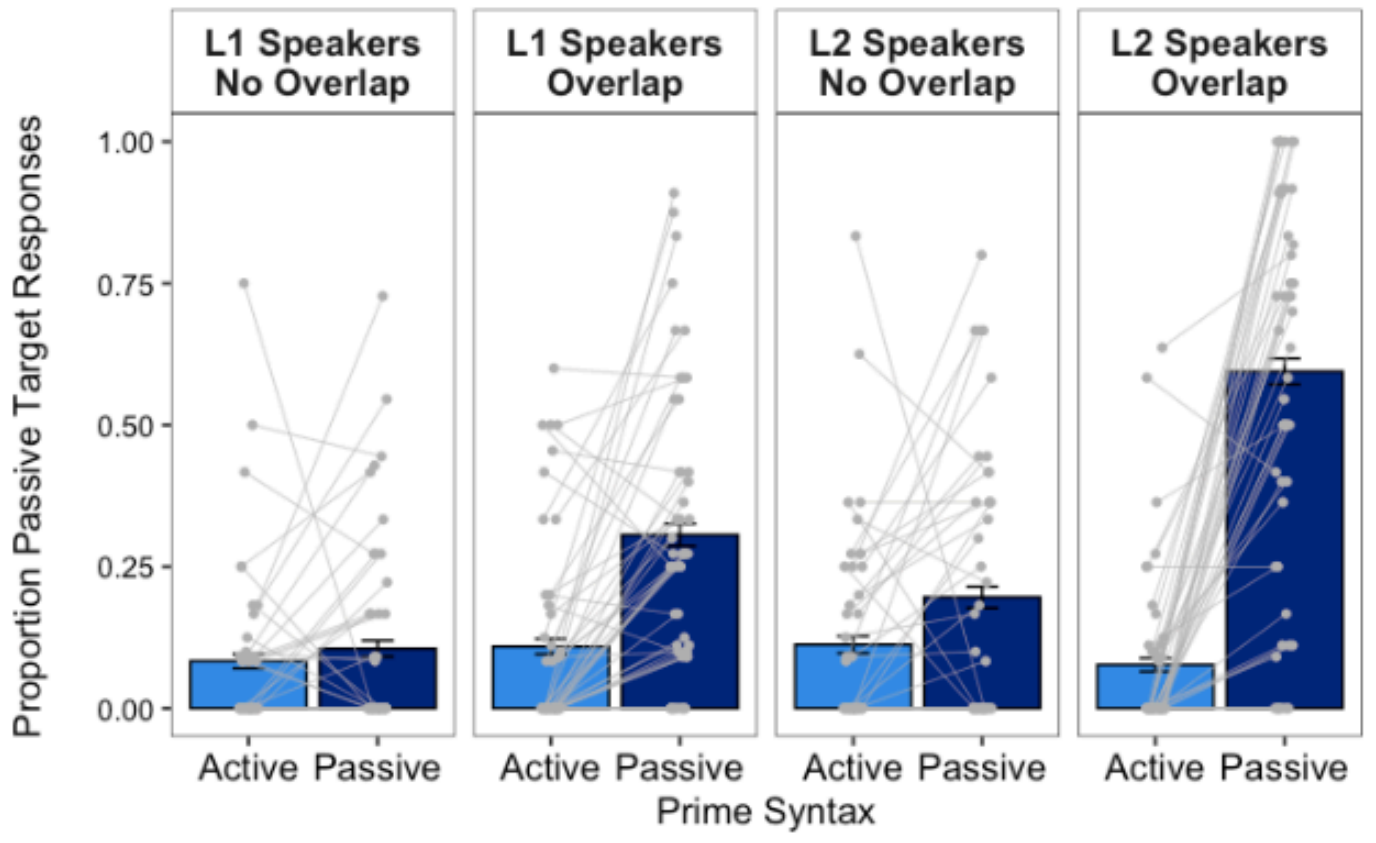

Figure 9. Passive responses in the priming phase. Mean proportion of passive responses out of all transitive descriptions by prime syntax, overlap and group conditions in the immediate priming phase. Error bars indicate the standard error of the mean, grey dots indicate individual data points and grey lines individual priming effects. 


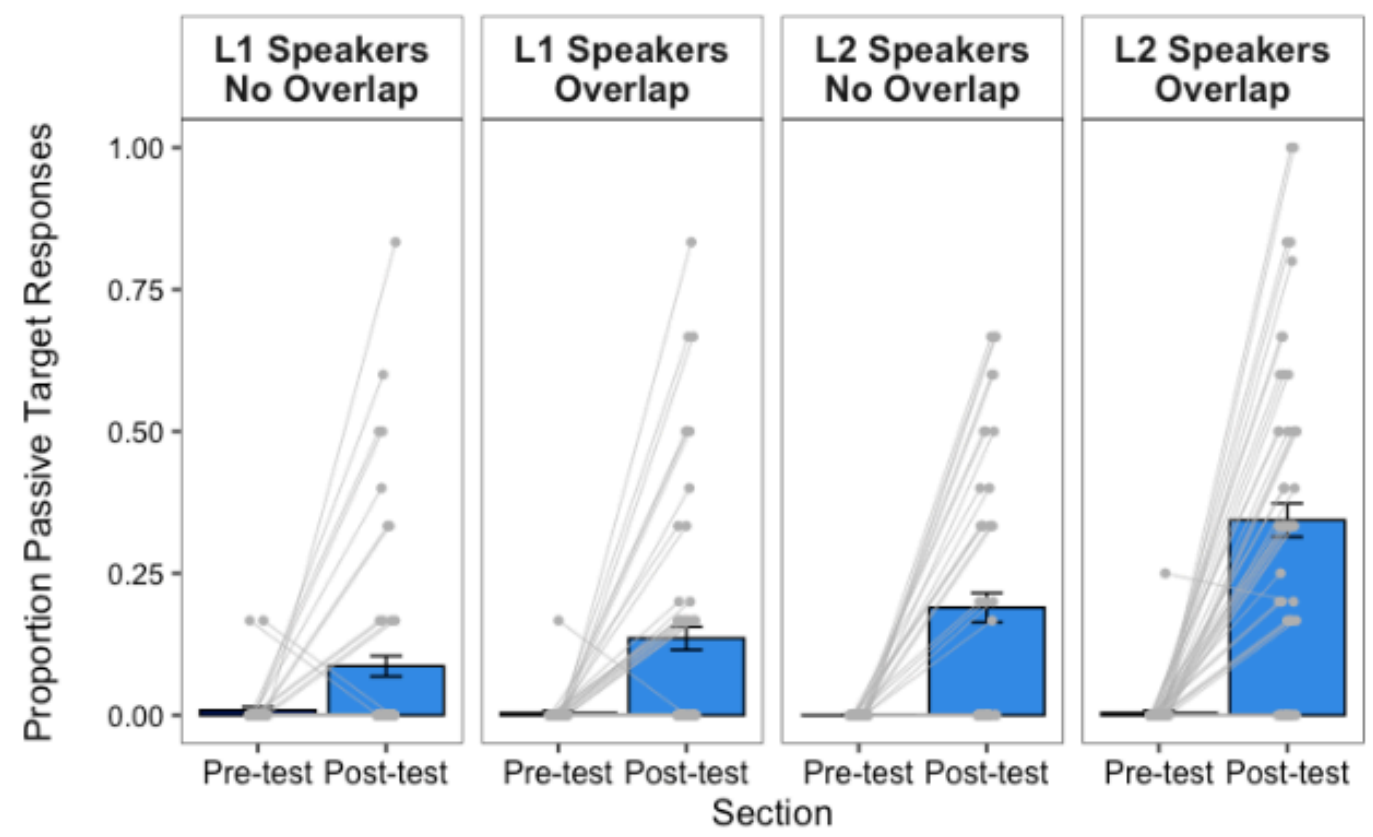

Figure 10. Passive responses in the pre- and post-tests. Mean proportion of passive responses out of all transitive responses by section, overlap and group conditions. Error bars indicate the standard error of the mean, grey dots indicate individual data points and grey lines individual priming effects.

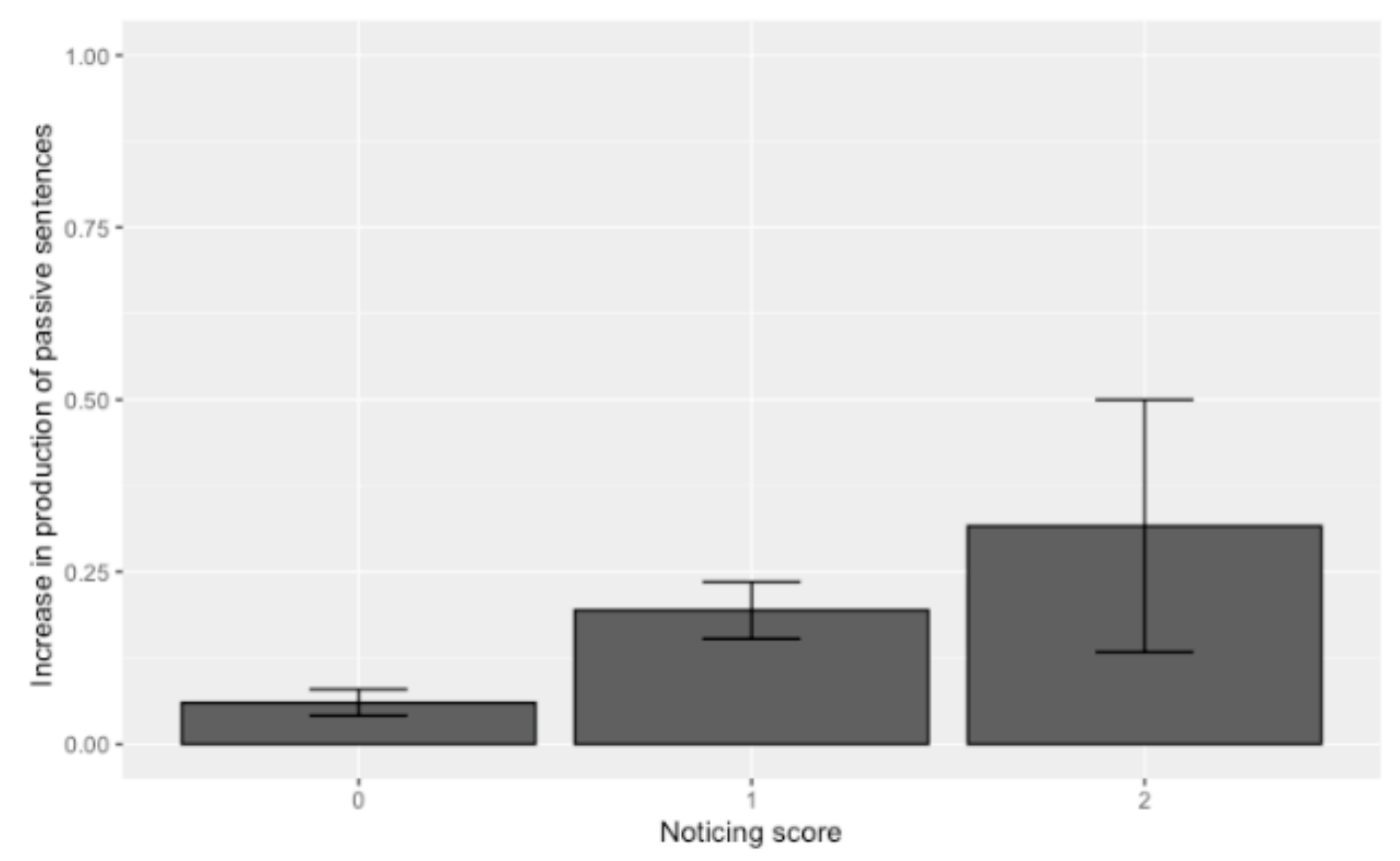

Figure 11. Noticing in Study 2. Increase in production of passive sentences between the preand post-test as a function of Noticing in both speaker groups in the condition without Lexical Overlap. The bars represent the standard error. $0=$ not noticing the target structure at all, $1=$ noticing it (Noticing 1 ) and $2=$ noticing it and understanding it (Noticing 2). 


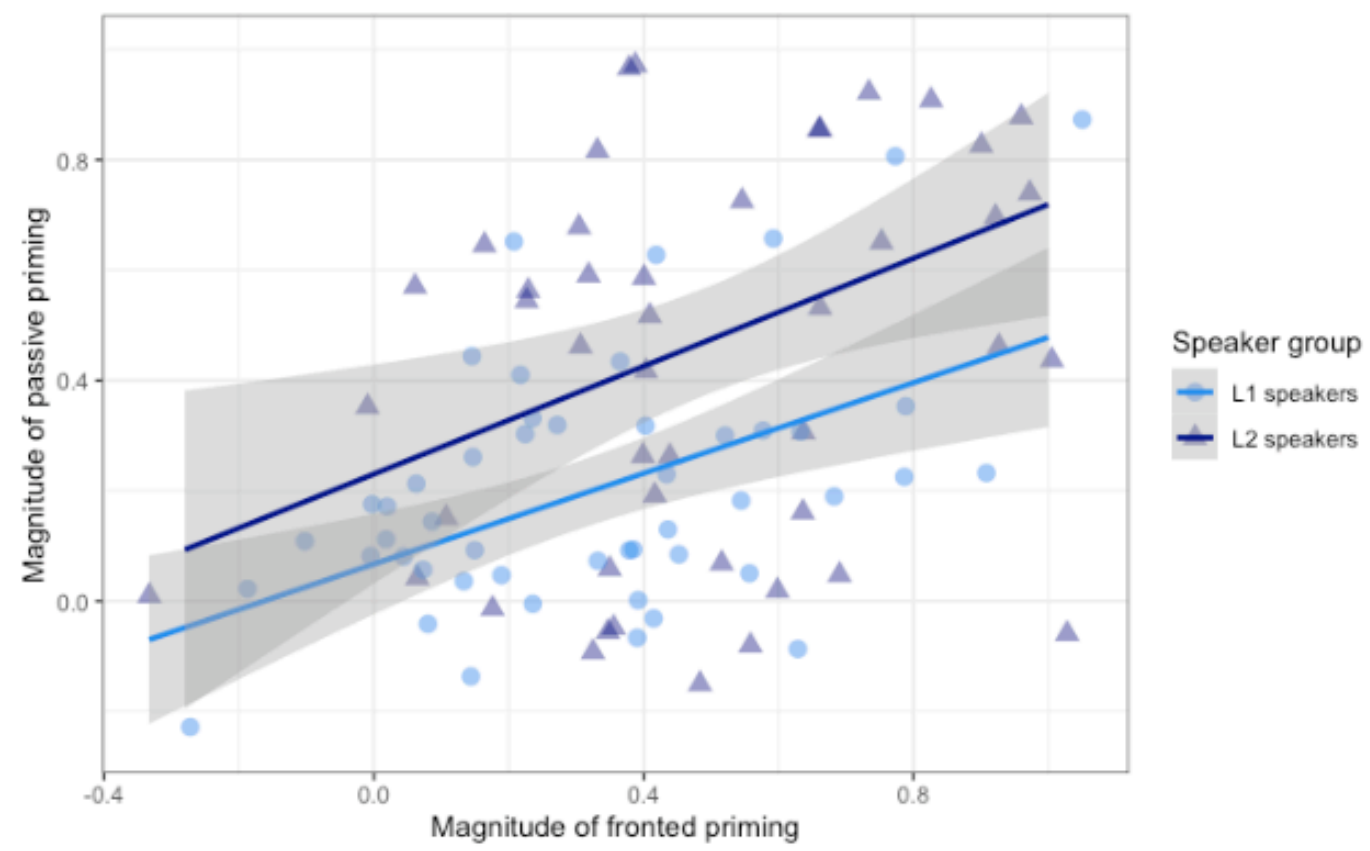

Figure 12. Relationship between immediate priming across studies. Scatterplot representing the correlation between immediate priming for passives and fronted sentences in L1 and L2 speakers with lexical overlap. The grey areas represent the confidence intervals.

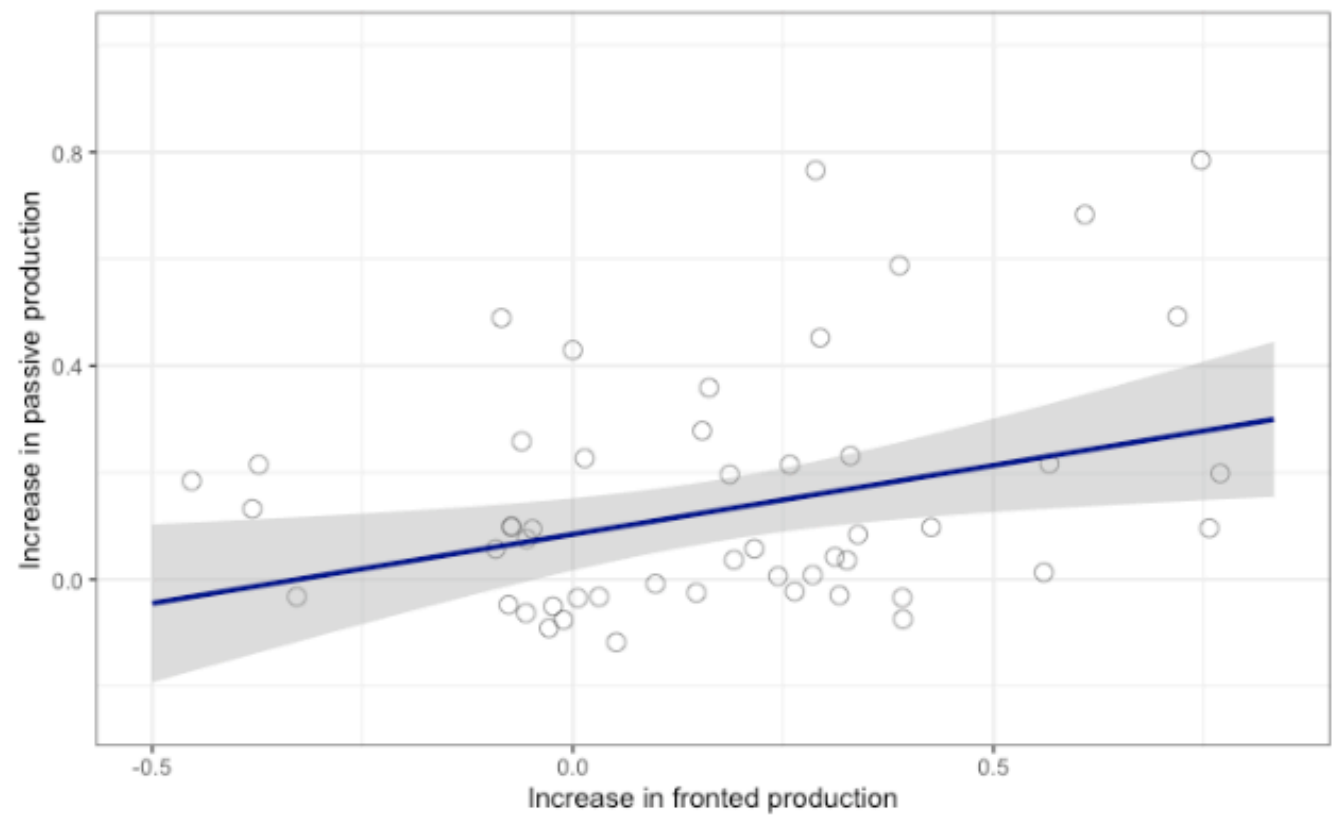

Figure 14. Relationship between long-term priming across studies. Scatterplot representing the correlation between long-term priming for passives and fronted sentences in L1 speakers with lexical overlap. The grey area represents the confidence interval. 


\section{Appendices}

Appendix A. Fronted/ Non-fronted material, experimental items.

Although the prime sentences are here presented with fronted temporal adverbial phrases, they also had an associated sentence with non-fronted temporal adverbial phrases.

\begin{tabular}{|c|c|c|c|}
\hline $\begin{array}{l}\text { Section of the } \\
\text { experiment }\end{array}$ & $\begin{array}{l}\text { Prime sentence with } \\
\text { overlap }\end{array}$ & $\begin{array}{l}\text { Prime sentence without } \\
\text { overlap }\end{array}$ & Target sentence \\
\hline Pre-test & $\begin{array}{l}\text { Les serveuses sourient } \\
\text { The waitresses are smiling }\end{array}$ & $\begin{array}{l}\text { Les serveuses sourient } \\
\text { The waitresses are smiling }\end{array}$ & $\begin{array}{l}\text { A huit heures, le boxeur } \\
\text { écoute le nageur } \\
\text { At } 8 \text {, the boxer listens to the } \\
\text { swimmer }\end{array}$ \\
\hline Pre-test & $\begin{array}{l}\text { Les nageurs marchent } \\
\text { The swimmers are walking }\end{array}$ & $\begin{array}{l}\text { Les nageurs marchent } \\
\text { The swimmers are } \\
\text { walking }\end{array}$ & $\begin{array}{l}\text { Chaque lundi, le soldat rend } \\
\text { le livre } \\
\text { Every Monday, the soldier } \\
\text { gives the book back }\end{array}$ \\
\hline Pre-test & $\begin{array}{l}\text { La ballerine mange la } \\
\text { pomme de sa grand-mère } \\
\text { The ballerina eats the apple } \\
\text { of her grandmother }\end{array}$ & $\begin{array}{l}\text { La ballerine mange la } \\
\text { pomme de sa grand-mère } \\
\text { The ballerina eats the } \\
\text { apple of her grandmother }\end{array}$ & $\begin{array}{l}\text { En hiver, le docteur porte un } \\
\text { pantalon } \\
\text { In winter, the doctor wears } \\
\text { pants }\end{array}$ \\
\hline Pre-test & $\begin{array}{l}\text { Le clown frappe le gâteau } \\
\text { de sa soeur } \\
\text { The clown hits the cake of } \\
\text { his sister }\end{array}$ & $\begin{array}{l}\text { Le clown frappe le gâteau } \\
\text { de sa soeur } \\
\text { The clown hits the cake of } \\
\text { his sister }\end{array}$ & $\begin{array}{l}\text { A midi, le moine sert des } \\
\text { boissons } \\
\text { At } 12 \text {, the monk serves } \\
\text { drinks }\end{array}$ \\
\hline Pre-test & $\begin{array}{l}\text { Le nageur donne la banane } \\
\text { au boxeur } \\
\text { The swimmer gives the } \\
\text { banana to the boxer }\end{array}$ & $\begin{array}{l}\text { Le nageur donne la } \\
\text { banane au boxeur } \\
\text { The swimmer gives the } \\
\text { banana to the boxer }\end{array}$ & $\begin{array}{l}\text { Chaque mardi, le marin } \\
\text { achète une carafe } \\
\text { Every Tuesday, the sailor } \\
\text { buys a carafe }\end{array}$ \\
\hline Pre-test & $\begin{array}{l}\text { Le marin offre la carafe à la } \\
\text { ballerine } \\
\text { The sailor offers the carafe } \\
\text { to the ballerina }\end{array}$ & $\begin{array}{l}\text { Le marin offre la carafe à } \\
\text { la ballerine } \\
\text { The sailor offers the } \\
\text { carafe to the ballerina }\end{array}$ & $\begin{array}{l}\text { En été, le voleur fait une } \\
\text { promenade } \\
\text { In summer, the robber goes } \\
\text { for walks }\end{array}$ \\
\hline Priming phase & $\begin{array}{l}\text { A deux heures, la ballerine } \\
\text { écoute le professeur } \\
\text { At } 2 \text {, the ballerina listens to } \\
\text { the policeman }\end{array}$ & $\begin{array}{l}\text { En hiver, la serveuse sert } \\
\text { des bananes } \\
\text { In winter, the waitress } \\
\text { serves bananas }\end{array}$ & $\begin{array}{l}\text { En hiver, l'artiste porte des } \\
\text { bottes } \\
\text { In winter, the artist wears } \\
\text { boots }\end{array}$ \\
\hline Priming phase & $\begin{array}{l}\text { A huit heures, le cowboy } \\
\text { rend le ballon } \\
\text { At } 8 \text {, the cowboy gives the } \\
\text { ball back }\end{array}$ & $\begin{array}{l}\text { Chaque jeudi, la bonne } \\
\text { soeur fait une randonnée } \\
\text { Every Thursday, the nun } \\
\text { goes for a walk }\end{array}$ & $\begin{array}{l}\text { Chaque jeudi, le marin } \\
\text { achète un livre } \\
\text { Every Thursday, the sailor } \\
\text { buys a book }\end{array}$ \\
\hline Priming phase & $\begin{array}{l}\text { A midi, le marin écoute le } \\
\text { boxeur } \\
\text { At } 12, \text { the sailor listens to } \\
\text { the boxer }\end{array}$ & $\begin{array}{l}\text { En été, la bonne soeur sert } \\
\text { des boissons } \\
\text { In summer, the nun serves } \\
\text { serves drinks }\end{array}$ & $\begin{array}{l}\text { En été, le cowboy porte un } \\
\text { chapeau } \\
\text { In summer, the cowboy } \\
\text { wears a hat }\end{array}$ \\
\hline Priming phase & $\begin{array}{l}\text { En automne, la bonne soeur } \\
\text { sert des gâteaux } \\
\text { In autumn, the nun serves } \\
\text { cakes }\end{array}$ & $\begin{array}{l}\text { A midi, le cowboy rend le } \\
\text { pistolet } \\
\text { At } 12, \text { the cowboy gives } \\
\text { the gun back }\end{array}$ & $\begin{array}{l}\text { A midi, la ballerine écoute le } \\
\text { nageur } \\
\text { At } 12 \text {, the ballerina listens to } \\
\text { the swimmer }\end{array}$ \\
\hline
\end{tabular}




\begin{tabular}{|c|c|c|c|}
\hline Priming phase & $\begin{array}{l}\text { A neuf heures, l'artiste rend } \\
\text { la tasse } \\
\text { At } 9, \text { the artist gives the cup } \\
\text { back }\end{array}$ & $\begin{array}{l}\text { Chaque samedi, la } \\
\text { serveuse fait un jogging } \\
\text { Every Saturday, the } \\
\text { waitress goes for a jog }\end{array}$ & $\begin{array}{l}\text { Chaque samedi, la ballerine } \\
\text { achète une carafe } \\
\text { Every Saturday, the } \\
\text { ballerina buys a carafe }\end{array}$ \\
\hline Priming phase & $\begin{array}{l}\text { En été, l'artiste porte une } \\
\text { chemise } \\
\text { In summer, the artist wears } \\
\text { a shirt }\end{array}$ & $\begin{array}{l}\text { Chaque lundi, la ballerine } \\
\text { achète un livre } \\
\text { Every Monday, the } \\
\text { ballerina buys a book }\end{array}$ & $\begin{array}{l}\text { Chaque lundi, la bonne } \\
\text { soeur fait un jogging } \\
\text { Every Monday, the nun goes } \\
\text { for a jog }\end{array}$ \\
\hline Priming phase & $\begin{array}{l}\text { Chaque lundi, la ballerine } \\
\text { achète un livre } \\
\text { Every Monday, the ballerina } \\
\text { buys a book }\end{array}$ & $\begin{array}{l}\text { A neuf heures, le marin } \\
\text { écoute le nageur } \\
\text { At 9, the sailor listens to } \\
\text { the swimmer }\end{array}$ & $\begin{array}{l}\text { A neuf heures, le cowboy } \\
\text { rend la banane } \\
\text { At } 9 \text {, the cowboy gives the } \\
\text { banana back }\end{array}$ \\
\hline Priming phase & $\begin{array}{l}\text { Au printemps, la serveuse } \\
\text { sert des pommes } \\
\text { In spring, the waitress } \\
\text { serves apples }\end{array}$ & $\begin{array}{l}\text { A huit heures, la ballerine } \\
\text { écoute le professeur } \\
\text { At } 8, \text { the ballerina listens } \\
\text { to the professor }\end{array}$ & $\begin{array}{l}\text { A huit heures, l'artiste rend } \\
\text { le pistolet } \\
\text { At } 8 \text {, the artist gives the gun } \\
\text { back }\end{array}$ \\
\hline Priming phase & $\begin{array}{l}\text { Chaque mardi, le marin } \\
\text { achète une carafe } \\
\text { Every Tuesday, the sailor } \\
\text { buys a carafe } \\
\end{array}$ & $\begin{array}{l}\text { Au printemps, l'artiste } \\
\text { porte un chapeau } \\
\text { In spring, the artist wears } \\
\text { a hat }\end{array}$ & $\begin{array}{l}\text { Au printemps, la bonne } \\
\text { soeur sert des bananes } \\
\text { In spring, the nun serves } \\
\text { bananas }\end{array}$ \\
\hline Priming phase & $\begin{array}{l}\text { En hiver, le cowboy porte } \\
\text { un pantalon } \\
\text { In winter, the cowboy wears } \\
\text { pants }\end{array}$ & $\begin{array}{l}\text { A deux heures, l'artiste } \\
\text { rend la banane } \\
\text { At 2, the artist gives the } \\
\text { banana back }\end{array}$ & $\begin{array}{l}\text { A deux heures, le marin } \\
\text { écoute le professeur } \\
\text { At 2, the sailor listens to the } \\
\text { professor }\end{array}$ \\
\hline phase & $\begin{array}{l}\text { Chaque mardi, la bonne } \\
\text { sœur fait une promenade } \\
\text { Every Tuesday, the nun goes } \\
\text { for a walk }\end{array}$ & $\begin{array}{l}\text { A deux heures, la } \\
\text { ballerine écoute le policier } \\
\text { At 2, the ballerina listens } \\
\text { to the policeman }\end{array}$ & $\begin{array}{l}\text { A deux heures, le cowboy } \\
\text { rend la tasse } \\
\text { At } 2 \text {, the cowboy gives the } \\
\text { cup back }\end{array}$ \\
\hline Priming phase & $\begin{array}{l}\text { Chaque samedi, la serveuse } \\
\text { fait un jogging } \\
\text { Every Saturday, the waitress } \\
\text { goes for a jog }\end{array}$ & $\begin{array}{l}\text { Au printemps, la serveuse } \\
\text { sert des pommes } \\
\text { In spring, the waitress } \\
\text { serves apples }\end{array}$ & $\begin{array}{l}\text { Au printemps, le cowboy } \\
\text { porte une chemise } \\
\text { In spring, the cowboy wears } \\
\text { a shirt }\end{array}$ \\
\hline Priming phase & $\begin{array}{l}\text { A huit heures, la ballerine } \\
\text { écoute le professeur } \\
\text { At } 8 \text {, the ballerina listens to } \\
\text { the professor }\end{array}$ & $\begin{array}{l}\text { Chaque lundi, la serveuse } \\
\text { fait une randonnée } \\
\text { Every Monday, the } \\
\text { waitress goes hiking }\end{array}$ & $\begin{array}{l}\text { Chaque lundi, le marin } \\
\text { achète un chapeau } \\
\text { Every Monday, the sailor } \\
\text { buys a hat }\end{array}$ \\
\hline Priming phase & $\begin{array}{l}\text { A deux heures, l'artiste rend } \\
\text { la banane } \\
\text { At } 2 \text {, the artist gives the } \\
\text { banana back }\end{array}$ & $\begin{array}{l}\text { En automne, le cowboy } \\
\text { porte des bottes } \\
\text { In autumn, the cowboy } \\
\text { wears boots }\end{array}$ & $\begin{array}{l}\text { En automne, la serveuse sert } \\
\text { des boissons } \\
\text { In autumn, the waitress } \\
\text { serves drinks }\end{array}$ \\
\hline Priming phase & $\begin{array}{l}\text { A midi, le cowboy rend le } \\
\text { pistolet } \\
\text { At } 12 \text {, the cowboy gives the } \\
\text { gun back }\end{array}$ & $\begin{array}{l}\text { En été, l'artiste porte une } \\
\text { chemise } \\
\text { In summer, the artist } \\
\text { wears a shirt }\end{array}$ & $\begin{array}{l}\text { En été, la serveuse sert des } \\
\text { gâteaux } \\
\text { In summer, the waitress } \\
\text { serves cakes }\end{array}$ \\
\hline Priming phase & $\begin{array}{l}\text { A neuf heures, le marin } \\
\text { écoute le nageur } \\
\text { At } 9 \text {, the sailor listens to the } \\
\text { swimmer }\end{array}$ & $\begin{array}{l}\text { Chaque samedi, le marin } \\
\text { achète un fusil } \\
\text { Every Saturday, the sailor } \\
\text { buys a rifle }\end{array}$ & $\begin{array}{l}\text { Chaque samedi, la bonne } \\
\text { soeur fait une randonnée } \\
\text { Every Saturday, the nun } \\
\text { goes hiking }\end{array}$ \\
\hline Priming phase & $\begin{array}{l}\text { Chaque mardi, la bonne } \\
\text { soeur fait du sport }\end{array}$ & $\begin{array}{l}\text { A huit heures, le cowboy } \\
\text { rend le ballon }\end{array}$ & $\begin{array}{l}\text { A huit heures, le marin } \\
\text { écoute le policier }\end{array}$ \\
\hline
\end{tabular}




\begin{tabular}{|c|c|c|c|}
\hline & $\begin{array}{l}\text { Every Tuesday, the nun does } \\
\text { sport }\end{array}$ & $\begin{array}{l}\text { At } 8, \text { the cowboy gives the } \\
\text { ball back }\end{array}$ & $\begin{array}{l}\text { At } 8, \text { the sailor listens to the } \\
\text { policeman }\end{array}$ \\
\hline Priming phase & $\begin{array}{l}\text { En été, la bonne soeur sert } \\
\text { des boissons } \\
\text { In summer, the nun serves } \\
\text { serves drinks }\end{array}$ & $\begin{array}{l}\text { Chaque mardi, la bonne } \\
\text { sœur fait du sport } \\
\text { Every Tuesday, the nun } \\
\text { does sport }\end{array}$ & $\begin{array}{l}\text { Chaque mardi, la ballerine } \\
\text { achète un fusil } \\
\text { Every Tuesday, the ballerina } \\
\text { buys a rifle }\end{array}$ \\
\hline Priming phase & $\begin{array}{l}\text { Chaque jeudi, la ballerine } \\
\text { achète un chapeau } \\
\text { Every Thursday, the } \\
\text { ballerina buys a hat }\end{array}$ & $\begin{array}{l}\text { A midi, le marin écoute le } \\
\text { boxeur } \\
\text { At } 12, \text { the sailor listens to } \\
\text { the boxer }\end{array}$ & $\begin{array}{l}\text { A midi, l'artiste rend le } \\
\text { ballon } \\
\text { At } 12, \text { the artist gives the } \\
\text { ball back }\end{array}$ \\
\hline Priming phase & $\begin{array}{l}\text { En hiver, la serveuse sert } \\
\text { des bananes } \\
\text { In winter, the waitress } \\
\text { serves bananas }\end{array}$ & $\begin{array}{l}\text { A neuf heures, l'artiste } \\
\text { rend la tasse } \\
\text { At 9, the artist gives the } \\
\text { cup back }\end{array}$ & $\begin{array}{l}\text { A neuf heures, la ballerine } \\
\text { écoute le boxeur } \\
\text { At } 9 \text {, the ballerina listens to } \\
\text { the boxer }\end{array}$ \\
\hline Priming phase & $\begin{array}{l}\text { Chaque samedi, le marin } \\
\text { achète un fusil } \\
\text { Every Saturday, the sailor } \\
\text { buys a rifle }\end{array}$ & $\begin{array}{l}\text { En automne, la bonne } \\
\text { soeur sert des gâteaux } \\
\text { In autumn, the nun serves } \\
\text { the cake }\end{array}$ & $\begin{array}{l}\text { En automne, l'artiste porte } \\
\text { un pantalon } \\
\text { In autumn, the artist wears } \\
\text { pants }\end{array}$ \\
\hline Priming phase & $\begin{array}{l}\text { Chaque lundi, la serveuse } \\
\text { fait une randonnée } \\
\text { Every Monday, the waitress } \\
\text { goes hiking }\end{array}$ & $\begin{array}{l}\text { En hiver, le cowboy porte } \\
\text { un pantalon } \\
\text { In winter, the cowboy } \\
\text { wears pants }\end{array}$ & $\begin{array}{l}\text { En hiver, la bonne sœur sert } \\
\text { des pommes } \\
\text { In winter, the nun serves } \\
\text { apples }\end{array}$ \\
\hline Priming phase & $\begin{array}{l}\text { Au printemps, l'artiste porte } \\
\text { un chapeau } \\
\text { In spring, the artist wears a } \\
\text { hat }\end{array}$ & $\begin{array}{l}\text { Chaque mardi, le marin } \\
\text { achète une carafe } \\
\text { Every Tuesday, the sailor } \\
\text { buys a carafe }\end{array}$ & $\begin{array}{l}\text { Chaque mardi, la serveuse } \\
\text { fait une promenade } \\
\text { Every Tuesday, the waitress } \\
\text { goes for a walk }\end{array}$ \\
\hline Priming phase & $\begin{array}{l}\text { En automne, le cowboy } \\
\text { porte des bottes } \\
\text { In autumn, the cowboy } \\
\text { wears boots }\end{array}$ & $\begin{array}{l}\text { Chaque jeudi, la ballerine } \\
\text { achète un chapeau } \\
\text { Every Thursday, the } \\
\text { ballerina buys a hat }\end{array}$ & $\begin{array}{l}\text { Chaque jeudi, la serveuse } \\
\text { fait du sport } \\
\text { Every Thursday, the waitress } \\
\text { does sport }\end{array}$ \\
\hline Post-test & $\begin{array}{l}\text { Les cuisiniers sourient } \\
\text { The cooks are smiling }\end{array}$ & $\begin{array}{l}\text { Les cuisiniers sourient } \\
\text { The cooks are smiling }\end{array}$ & $\begin{array}{l}\text { A huit heures, le boxeur sert } \\
\text { des boissons } \\
\text { At } 8 \text {, the boxer serves drinks }\end{array}$ \\
\hline Post-test & $\begin{array}{l}\text { Les artistes marchent } \\
\text { The artists are walking }\end{array}$ & $\begin{array}{l}\text { Les artistes marchent } \\
\text { The artists are walking }\end{array}$ & $\begin{array}{l}\text { Chaque lundi, le moine } \\
\text { achète une carafe } \\
\text { Every Monday, the monk } \\
\text { buys a carafe }\end{array}$ \\
\hline Post-test & $\begin{array}{l}\text { La ballerine frappe le gâteau } \\
\text { de sa soeur } \\
\text { The ballerina hits the cake } \\
\text { of her sister }\end{array}$ & $\begin{array}{l}\text { La ballerine frappe le } \\
\text { gâteau de sa soeur } \\
\text { The ballerina hits the cake } \\
\text { of her sister }\end{array}$ & $\begin{array}{l}\text { En été, le docteur fait une } \\
\text { promenade } \\
\text { In summer, the doctor goes } \\
\text { for a walk }\end{array}$ \\
\hline Post-test & $\begin{array}{l}\text { Le clown lâche la tasse de } \\
\text { sa grand-mère } \\
\text { The clown drops the cup of } \\
\text { his grandmother }\end{array}$ & $\begin{array}{l}\text { Le clown lâche la tasse de } \\
\text { sa grand-mère } \\
\text { The clown drops the cup } \\
\text { of his grandmother }\end{array}$ & $\begin{array}{l}\text { A midi, le soldat écoute la } \\
\text { ballerine } \\
\text { At } 12 \text {, the soldier listens to } \\
\text { the ballerina }\end{array}$ \\
\hline Post-test & $\begin{array}{l}\text { Le pirate offre la carafe du } \\
\text { clown } \\
\text { The pirate offers the carafe } \\
\text { to the clown }\end{array}$ & $\begin{array}{l}\text { Le pirate offre la carafe du } \\
\text { clown } \\
\text { The pirate offers the } \\
\text { carafe to the clown }\end{array}$ & $\begin{array}{l}\text { Chaque mardi, le marin rend } \\
\text { un livre } \\
\text { Every Tuesday, the sailor } \\
\text { gives a book back }\end{array}$ \\
\hline
\end{tabular}




\begin{tabular}{|l|l|l|l|}
\hline Post-test & $\begin{array}{l}\text { La bonne soeur donne la } \\
\text { banana au docteur } \\
\text { The nun gives the banana to } \\
\text { the doctor }\end{array}$ & $\begin{array}{l}\text { La bonne soeur donne la } \\
\text { banana au docteur } \\
\text { The nun gives the banana } \\
\text { to the doctor }\end{array}$ & $\begin{array}{l}\text { En hiver, le voleur porte un } \\
\text { pantalon } \\
\text { In winter, the robber wears } \\
\text { pants }\end{array}$ \\
\hline
\end{tabular}

Appendix B. Active/ Passive material, experimental items.

Although the prime sentences are here presented in the active form, they also had an associated passive form.

\begin{tabular}{|c|c|c|c|}
\hline $\begin{array}{l}\text { Section of the } \\
\text { experiment }\end{array}$ & $\begin{array}{l}\text { Prime sentence with } \\
\text { overlap }\end{array}$ & $\begin{array}{l}\text { Prime sentence without } \\
\text { overlap }\end{array}$ & Target sentence \\
\hline Pre-test & $\begin{array}{l}\text { Les voleurs sourient } \\
\text { The robbers are smiling }\end{array}$ & $\begin{array}{l}\text { Les voleurs sourient. } \\
\text { The robbers are smiling }\end{array}$ & $\begin{array}{l}\text { Le boxeur pourchasse le } \\
\text { policier } \\
\text { The boxer is chasing the } \\
\text { policeman }\end{array}$ \\
\hline Pre-test & $\begin{array}{l}\text { Les docteurs marchent } \\
\text { The doctors are walking }\end{array}$ & $\begin{array}{l}\text { Les docteurs marchent } \\
\text { The doctors are walking }\end{array}$ & $\begin{array}{l}\text { Le soldat suit le nageur } \\
\text { The soldier is following the } \\
\text { swimmer }\end{array}$ \\
\hline Pre-test & $\begin{array}{l}\text { Les cowboys tombent } \\
\text { The cowboys are falling }\end{array}$ & $\begin{array}{l}\text { Les cowboys tombent } \\
\text { The cowboys are falling }\end{array}$ & $\begin{array}{l}\text { Le docteur tape la ballerine } \\
\text { The doctor is punching the } \\
\text { ballerina }\end{array}$ \\
\hline Pre-test & $\begin{array}{l}\text { La ballerine donne la carafe } \\
\text { au clown } \\
\text { The ballerina is giving the } \\
\text { carafe to the clown }\end{array}$ & $\begin{array}{l}\text { La ballerine donne la } \\
\text { carafe au clown } \\
\text { The ballerina is giving the } \\
\text { carafe to the clown }\end{array}$ & $\begin{array}{l}\text { Le voleur gifle le professeur } \\
\text { The robber is slapping the } \\
\text { professor }\end{array}$ \\
\hline Pre-test & $\begin{array}{l}\text { Le clown passe le livre à la } \\
\text { ballerine } \\
\text { The clown is handing the } \\
\text { book to the ballerina }\end{array}$ & $\begin{array}{l}\text { Le clown passe le livre à } \\
\text { la ballerine } \\
\text { The clown is handing the } \\
\text { book to the ballerina }\end{array}$ & $\begin{array}{l}\text { Le marin embrasse la bonne } \\
\text { soeur } \\
\text { The sailor is kissing the nun }\end{array}$ \\
\hline Pre-test & $\begin{array}{l}\text { Le policier montre la banane } \\
\text { au professeur } \\
\text { The policeman is showing } \\
\text { the banana to the professor }\end{array}$ & $\begin{array}{l}\text { Le policier montre la } \\
\text { banane au professeur } \\
\text { The policeman is showing } \\
\text { the banana to the } \\
\text { professor }\end{array}$ & $\begin{array}{l}\text { Le moine gronde le clown } \\
\text { The monk is scolding the } \\
\text { clown }\end{array}$ \\
\hline Priming phase & $\begin{array}{l}\text { La serveuse frappe le clown } \\
\text { The waitress is kicking the } \\
\text { clown }\end{array}$ & $\begin{array}{l}\text { The waitress is chasing } \\
\text { the swimmer }\end{array}$ & $\begin{array}{l}\text { Le policier pourchasse le } \\
\text { voleur } \\
\text { The policeman is chasing the } \\
\text { robber }\end{array}$ \\
\hline Priming phase & $\begin{array}{l}\text { La serveuse frappe le voleur } \\
\text { The waitress is kicking the } \\
\text { robber }\end{array}$ & $\begin{array}{l}\text { Le voleur pourchasse la } \\
\text { ballerine } \\
\text { The robber is chasing the } \\
\text { waitress }\end{array}$ & $\begin{array}{l}\text { Le policier pourchasse le } \\
\text { nageur } \\
\text { The policeman is chasing the } \\
\text { swimmer }\end{array}$ \\
\hline Priming phase & $\begin{array}{l}\text { Le policier frappe le boxeur } \\
\text { The policeman is kicking the } \\
\text { boxer }\end{array}$ & $\begin{array}{l}\text { Le policier pourchasse la } \\
\text { ballerine } \\
\text { The policeman is chasing } \\
\text { the ballerina }\end{array}$ & $\begin{array}{l}\text { Le pirate pourchasse le } \\
\text { voleur } \\
\text { The pirate is chasing the } \\
\text { robber }\end{array}$ \\
\hline Priming phase & Le policier frappe le clown & $\begin{array}{l}\text { Le policier pourchasse le } \\
\text { pirate }\end{array}$ & $\begin{array}{l}\text { La serveuse pourchasse la } \\
\text { ballerine }\end{array}$ \\
\hline
\end{tabular}




\begin{tabular}{|c|c|c|c|}
\hline & $\begin{array}{l}\text { The policeman is kicking the } \\
\text { clown }\end{array}$ & $\begin{array}{l}\text { The policeman is chasing } \\
\text { the pirate }\end{array}$ & $\begin{array}{l}\text { The waitress is chasing the } \\
\text { ballerina }\end{array}$ \\
\hline Priming phase & $\begin{array}{l}\text { Le cowboy pousse le nageur } \\
\text { The cowboy is pushing the } \\
\text { swimmer }\end{array}$ & $\begin{array}{l}\text { Le soldat suit le docteur } \\
\text { The soldier is following } \\
\text { the doctor }\end{array}$ & $\begin{array}{l}\text { Le pirate suit le marin } \\
\text { The pirate is following the } \\
\text { sailor }\end{array}$ \\
\hline Priming phase & $\begin{array}{l}\text { Le cuisinier pousse le clown } \\
\text { The cook is pushing the } \\
\text { clown }\end{array}$ & $\begin{array}{l}\text { Le marin suit la bonne } \\
\text { soeur } \\
\text { The sailor is following the } \\
\text { nun }\end{array}$ & $\begin{array}{l}\text { Le pirate suit le docteur } \\
\text { The pirate is following the } \\
\text { doctor }\end{array}$ \\
\hline Priming phase & $\begin{array}{l}\text { Le cowboy pousse la } \\
\text { ballerine } \\
\text { The cowboy is pushing the } \\
\text { ballerina }\end{array}$ & $\begin{array}{l}\text { Le docteur suit le marin } \\
\text { The doctor is following } \\
\text { the sailor }\end{array}$ & $\begin{array}{l}\text { La bonne soeur suit le soldat } \\
\text { The nun is following the } \\
\text { soldier }\end{array}$ \\
\hline Priming phase & $\begin{array}{l}\text { Le cuisinier pousse le moine } \\
\text { The cook is pushing the } \\
\text { monk }\end{array}$ & $\begin{array}{l}\text { Le pirate suit le soldat } \\
\text { The pirate is following the } \\
\text { soldier }\end{array}$ & $\begin{array}{l}\text { La bonne soeur suit le } \\
\text { boxeur } \\
\text { The nun is following the } \\
\text { boxer }\end{array}$ \\
\hline Priming phase & $\begin{array}{l}\text { Le marin touche le nageur } \\
\text { The sailor is touching the } \\
\text { swimmer }\end{array}$ & $\begin{array}{l}\text { Le cowboy tape le docteur } \\
\text { The cowboy is punching } \\
\text { the doctor }\end{array}$ & $\begin{array}{l}\text { L'artiste tape le clown } \\
\text { The artist is punching the } \\
\text { clown }\end{array}$ \\
\hline Priming phase & $\begin{array}{l}\text { Le marin touche le clown } \\
\text { The sailor is touching the } \\
\text { clown }\end{array}$ & $\begin{array}{l}\text { Le cowboy tape le clown } \\
\text { The cowboy is punching } \\
\text { the clown }\end{array}$ & $\begin{array}{l}\text { L'artiste tape le docteur } \\
\text { The artist is punching the } \\
\text { doctor }\end{array}$ \\
\hline Priming phase & $\begin{array}{l}\text { La serveuse touche le marin } \\
\text { The waitress is touching the } \\
\text { sailor }\end{array}$ & $\begin{array}{l}\text { L'artiste tape le nageur } \\
\text { The artist is punching the } \\
\text { swimmer }\end{array}$ & $\begin{array}{l}\text { Le cowboy tape la ballerine } \\
\text { The cowboy is punching the } \\
\text { ballerina }\end{array}$ \\
\hline Priming phase & $\begin{array}{l}\text { La serveuse touche le } \\
\text { docteur } \\
\text { The waitress is touching the } \\
\text { doctor }\end{array}$ & $\begin{array}{l}\text { L'artiste tape la ballerine } \\
\text { The artist is punching the } \\
\text { ballerina }\end{array}$ & $\begin{array}{l}\text { Le cowboy tape le nageur } \\
\text { The cowboy is punching the } \\
\text { swimmer }\end{array}$ \\
\hline Priming phase & $\begin{array}{l}\text { Le cuisinier tue le boxeur } \\
\text { The cook is shooting the } \\
\text { boxer }\end{array}$ & $\begin{array}{l}\text { Le policier gronde le } \\
\text { soldat } \\
\text { The policeman is scolding } \\
\text { the soldier }\end{array}$ & $\begin{array}{l}\text { Le professeur gronde le } \\
\text { nageur } \\
\text { The professor is scolding the } \\
\text { swimmer }\end{array}$ \\
\hline Priming phase & $\begin{array}{l}\text { L'artiste tue le voleur } \\
\text { The artist is shooting the } \\
\text { robber }\end{array}$ & $\begin{array}{l}\text { Le professeur gronde le } \\
\text { boxeur } \\
\text { The professor is scolding } \\
\text { the boxer }\end{array}$ & $\begin{array}{l}\text { Le policier gronde la } \\
\text { ballerine } \\
\text { The policeman is scolding } \\
\text { the ballerina }\end{array}$ \\
\hline Priming phase & $\begin{array}{l}\text { Le cuisinier tue le nageur } \\
\text { The cook is shooting the } \\
\text { swimmer }\end{array}$ & $\begin{array}{l}\text { Le professeur gronde la } \\
\text { ballerine } \\
\text { The professor is scolding } \\
\text { the ballerina }\end{array}$ & $\begin{array}{l}\text { Le policier gronde le boxeur } \\
\text { The policeman is scolding } \\
\text { the boxer }\end{array}$ \\
\hline Priming phase & $\begin{array}{l}\text { L'artiste tue la ballerine } \\
\text { The artist is shooting the } \\
\text { ballerina }\end{array}$ & $\begin{array}{l}\text { Le policier gronde le } \\
\text { nageur } \\
\text { The policeman is scolding } \\
\text { the swimmer }\end{array}$ & $\begin{array}{l}\text { Le professeur gronde le } \\
\text { soldat } \\
\text { The professor is scolding the } \\
\text { soldier }\end{array}$ \\
\hline Priming phase & $\begin{array}{l}\text { Le pirate tire la ballerine } \\
\text { The pirate is pulling the } \\
\text { ballerina }\end{array}$ & $\begin{array}{l}\text { Le moine embrasse le } \\
\text { marin } \\
\text { The monk is kissing the } \\
\text { sailor }\end{array}$ & $\begin{array}{l}\text { La bonne soeur embrasse le } \\
\text { boxeur } \\
\text { The nun is kissing the boxer }\end{array}$ \\
\hline
\end{tabular}




\begin{tabular}{|c|c|c|c|}
\hline Priming phase & $\begin{array}{l}\text { Le boxeur tire le clown } \\
\text { The boxer is pulling the } \\
\text { clown }\end{array}$ & $\begin{array}{l}\text { La bonne soeur embrasse } \\
\text { le boxeur } \\
\text { The nun is kissing the } \\
\text { boxer }\end{array}$ & $\begin{array}{l}\text { L'artiste embrasse le soldat } \\
\text { The artist is kissing the } \\
\text { soldier }\end{array}$ \\
\hline Priming phase & $\begin{array}{l}\text { Le boxeur tire le soldat } \\
\text { The boxer is pulling the } \\
\text { soldier }\end{array}$ & $\begin{array}{l}\text { Le moine embrasse le } \\
\text { soldat } \\
\text { The monk is kissing the } \\
\text { soldier }\end{array}$ & $\begin{array}{l}\text { La bonne soeur embrasse la } \\
\text { ballerine } \\
\text { The nun is kissing the } \\
\text { ballerina }\end{array}$ \\
\hline Priming phase & $\begin{array}{l}\text { Le pirate tire le docteur } \\
\text { The pirate is pulling the } \\
\text { doctor }\end{array}$ & $\begin{array}{l}\text { La bonne soeur embrasse } \\
\text { le soldat } \\
\text { The nun is kissing the } \\
\text { soldier }\end{array}$ & $\begin{array}{l}\text { L'artiste embrasse le marin } \\
\text { The artist is kissing the } \\
\text { sailor }\end{array}$ \\
\hline Priming phase & $\begin{array}{l}\text { La serveuse chatouille le } \\
\text { voleur } \\
\text { The waitress is tickling the } \\
\text { robber }\end{array}$ & $\begin{array}{l}\text { Le docteur gifle le voleur } \\
\text { The doctor is slapping the } \\
\text { robber }\end{array}$ & $\begin{array}{l}\text { Le policier gifle le nageur } \\
\text { The policeman is slapping } \\
\text { the swimmer }\end{array}$ \\
\hline Priming phase & $\begin{array}{l}\text { La serveuse chatouille le } \\
\text { moine } \\
\text { The waitress is tickling the } \\
\text { monk }\end{array}$ & $\begin{array}{l}\text { Le voleur gifle le moine } \\
\text { The robber is slapping the } \\
\text { monk }\end{array}$ & $\begin{array}{l}\text { Le policier gifle le boxeur } \\
\text { The policeman is slapping } \\
\text { the boxer }\end{array}$ \\
\hline Priming phase & $\begin{array}{l}\text { Le soldat chatouille la } \\
\text { ballerine } \\
\text { The soldier is tickling the } \\
\text { ballerina }\end{array}$ & $\begin{array}{l}\text { Le docteur gifle le boxeur } \\
\text { The doctor is slapping the } \\
\text { boxer }\end{array}$ & $\begin{array}{l}\text { Le cowboy gifle le marin } \\
\text { The cowboy is slapping the } \\
\text { sailor }\end{array}$ \\
\hline Priming phase & $\begin{array}{l}\text { Le soldat chatouille le } \\
\text { voleur } \\
\text { The soldier is tickling the } \\
\text { robber }\end{array}$ & $\begin{array}{l}\text { Le voleur gifle le nageur } \\
\text { The robber is slapping the } \\
\text { swimmer }\end{array}$ & $\begin{array}{l}\text { Le cowboy gifle la ballerine } \\
\text { The cowboy is slapping the } \\
\text { ballerina }\end{array}$ \\
\hline Post-test & $\begin{array}{l}\text { Les cowboys rigolent } \\
\text { The cowboys are laughing }\end{array}$ & $\begin{array}{l}\text { Les cowboys rigolent } \\
\text { The cowboys are laughing }\end{array}$ & $\begin{array}{l}\text { Le marin pourchasse le } \\
\text { policier } \\
\text { The sailor is chasing the } \\
\text { policeman }\end{array}$ \\
\hline Post-test & $\begin{array}{l}\text { Les professeurs sourient } \\
\text { The professors are smiling }\end{array}$ & $\begin{array}{l}\text { Les professeurs sourient } \\
\text { The professors are smiling }\end{array}$ & $\begin{array}{l}\text { Le soldat suit la ballerine } \\
\text { The soldier is following the } \\
\text { ballerina }\end{array}$ \\
\hline Post-test & $\begin{array}{l}\text { Les soldats marchent } \\
\text { The soldiers are walking }\end{array}$ & $\begin{array}{l}\text { Les soldats marchent } \\
\text { The soldiers are walking }\end{array}$ & $\begin{array}{l}\text { Le voleur tape le clown } \\
\text { The robber is punching the } \\
\text { clown }\end{array}$ \\
\hline Post-test & $\begin{array}{l}\text { La ballerine offre la carafe } \\
\text { au clown } \\
\text { The ballerina is offering the } \\
\text { carafe to the clown }\end{array}$ & $\begin{array}{l}\text { La ballerine offre la carafe } \\
\text { au clown } \\
\text { The ballerina is offering } \\
\text { the carafe to the clown }\end{array}$ & $\begin{array}{l}\text { Le boxeur gronde le } \\
\text { professeur } \\
\text { The boxer is scolding the } \\
\text { professor }\end{array}$ \\
\hline Post-test & $\begin{array}{l}\text { Le clown vend le livre au } \\
\text { professeur } \\
\text { The clown is selling the } \\
\text { book to the professor }\end{array}$ & $\begin{array}{l}\text { Le clown vend le livre au } \\
\text { professeur } \\
\text { The clown is selling the } \\
\text { book to the professor }\end{array}$ & $\begin{array}{l}\text { Le moine embrasse la bonne } \\
\text { soeur } \\
\text { The monk is kissing the nun }\end{array}$ \\
\hline Post-test & $\begin{array}{l}\text { Le policier lance la banana à } \\
\text { la ballerine } \\
\text { The policeman is throwing } \\
\text { the banana to the ballerina }\end{array}$ & $\begin{array}{l}\text { Le policier lance la } \\
\text { banana à la ballerine }\end{array}$ & $\begin{array}{l}\text { Le docteur gifle le nageur } \\
\text { The doctor is slapping the } \\
\text { swimmer }\end{array}$ \\
\hline
\end{tabular}


The policeman is throwing

the banana to the

ballerina

Appendix C. Motivation questionnaire.

This questionnaire was filled in on a laptop in the lab, using Qualtrics. The order of the questions was randomized across participants. In brackets, we indicate the motivation category each item belonged to.

This questionnaire consists of two sections. Please read each sentence carefully and select your rating. This is not a test so there are no "right" or "wrong" answers. The results of this survey will be used only for research purposes so please give your answers sincerely.

In this first section, you will need to indicate WHY you are learning French by rating to what extent you agree with each of the statements written below. Use the bar to select a number between 1 and 7 . Please use the full range of the scale.

1) I am learning French because ...my parents (my family or someone else) want me to speak French. (External motivation)

\begin{tabular}{|l|l|l|l|l|l|l|}
\hline 1 & 2 & 3 & 4 & 5 & 6 & 7 \\
\hline
\end{tabular}

2) I am learning French because ...I want to become more educated. (External motivation)

\begin{tabular}{|c|l|l|l|l|l|l|}
\hline 1 & 2 & 3 & 4 & 5 & 6 & 7 \\
\hline
\end{tabular}

3) I am learning French because ... it is important to show my ability in French to my family/ friends/ teachers. (External motivation)

\begin{tabular}{|l|l|l|l|l|l|l|}
\hline 1 & 2 & 3 & 4 & 5 & 6 & 7 \\
\hline
\end{tabular}

4) I am learning French because ... learning French is a hobby for me. (Intrinsic motivation)

\begin{tabular}{|c|c|c|c|c|c|c|}
\hline 1 & 2 & 3 & 4 & 5 & 6 & 7 \\
\hline
\end{tabular}

5) I am learning French because ...I want to manage to have basic conversations in French regardless of grammatical accuracy. (Learning goal)

\begin{tabular}{|l|l|l|l|l|l|l|}
\hline 1 & 2 & 3 & 4 & 5 & 6 & 7 \\
\hline
\end{tabular}

6) I am learning French because ... it will have a negative impact on my life if I don't learn French. (External motivation)

\begin{tabular}{|l|l|l|l|l|l|l|}
\hline 1 & 2 & 3 & 4 & 5 & 6 & 7 \\
\hline
\end{tabular}

7) I am learning French because ... without passing the French course I cannot get my degree. (External motivation)

\begin{tabular}{|c|c|c|c|c|c|c|}
\hline 1 & 2 & 3 & 4 & 5 & 6 & 7 \\
\hline
\end{tabular}

8) I am learning French because ... being able to speak French will add to my social status. (External motivation)

\begin{tabular}{|c|c|c|c|c|c|c|}
\hline 1 & 2 & 3 & 4 & 5 & 6 & 7 \\
\hline
\end{tabular}


9) I am learning French because ...I enjoy the experience of surpassing myself when speaking French. (Intrinsic motivation)

\begin{tabular}{|l|l|l|l|l|l|l|}
\hline 1 & 2 & 3 & 4 & 5 & 6 & 7 \\
\hline
\end{tabular}

10) I am learning French because ...I don't want to fail the French course. (Extrinsic motivation)

\begin{tabular}{|c|c|c|c|c|c|c|}
\hline 1 & 2 & 3 & 4 & 5 & 6 & 7 \\
\hline
\end{tabular}

11) I am learning French because ...I want to be able to speak French like a native speaker. (Learning goal)

\begin{tabular}{|l|l|l|l|l|l|l|}
\hline 1 & 2 & 3 & 4 & 5 & 6 & 7 \\
\hline
\end{tabular}

12) I am learning French because ... being able to speak French is something I personally value. (Personal value)

\begin{tabular}{|l|l|l|l|l|l|l|}
\hline 1 & 2 & 3 & 4 & 5 & 6 & 7 \\
\hline
\end{tabular}

13) I am learning French because ... it will allow me to get a better job. (Extrinsic motivation)

\begin{tabular}{|c|c|c|c|c|c|c|}
\hline 1 & 2 & 3 & 4 & 5 & 6 & 7 \\
\hline
\end{tabular}

14) I am learning French because ...learning French is one of the most important aspects of my life. (Personal value)

\begin{tabular}{|c|c|c|c|c|c|c|}
\hline 1 & 2 & 3 & 4 & 5 & 6 & 7 \\
\hline
\end{tabular}

15) I am learning French because ...I want to spend a period of time/ emigrate to a French-speaking country. (Extrinsic motivation)

\begin{tabular}{|c|c|c|c|c|c|c|}
\hline 1 & 2 & 3 & 4 & 5 & 6 & 7 \\
\hline
\end{tabular}

16) I am learning French because ...I want to be able to speak French without making any grammatical mistakes. (Learning goal)

\begin{tabular}{|c|c|c|c|c|c|c|}
\hline 1 & 2 & 3 & 4 & 5 & 6 & 7 \\
\hline
\end{tabular}

17) I am learning French because ...I want to be able to interact with French native speakers. (Learning goal)

\begin{tabular}{|c|c|c|c|c|c|c|}
\hline 1 & 2 & 3 & 4 & 5 & 6 & 7 \\
\hline
\end{tabular}

In this section, use the scale to indicate to what extent you agree with each of the following statements. Use the bar to select a number between 1 and 7. Please use the full range of the scale.

18) If I did it again, I would put more effort into doing the picture description task. (Task motivation)

\begin{tabular}{|c|c|c|c|c|c|c|}
\hline 1 & 2 & 3 & 4 & 5 & 6 & 7 \\
\hline
\end{tabular}

19) I always look forward to speaking French. (Intrinsic motivation)

\begin{tabular}{|l|l|l|l|l|l|l|}
\hline 1 & 2 & 3 & 4 & 5 & 6 & 7 \\
\hline
\end{tabular}


20) If my teacher were to give an optional assignment, I would certainly volunteer to do it. (Motivational intensity)

\begin{tabular}{|l|l|l|l|l|l|l|}
\hline 1 & 2 & 3 & 4 & 5 & 6 & 7 \\
\hline
\end{tabular}

21) I often think about the words and ideas that I learnt in my French classes.

(Motivational intensity)

\begin{tabular}{|c|c|c|c|c|c|c|}
\hline 1 & 2 & 3 & 4 & 5 & 6 & 7 \\
\hline
\end{tabular}

22) I did not put a lot of effort in doing the picture description task. (Task motivation)

\begin{tabular}{|l|l|l|l|l|l|l|}
\hline 1 & 2 & 3 & 4 & 5 & 6 & 7 \\
\hline
\end{tabular}

23) I am not worried about mistakes I make in French as long as I am understandable. (Learning goal)

\begin{tabular}{|l|l|l|l|l|l|l|}
\hline 1 & 2 & 3 & 4 & 5 & 6 & 7 \\
\hline
\end{tabular}

24) If I had the opportunity, I would spend more time doing tasks like the picture description task. (Task motivation)

\begin{tabular}{|l|l|l|l|l|l|l|}
\hline 1 & 2 & 3 & 4 & 5 & 6 & 7 \\
\hline
\end{tabular}

25) I am working hard at learning French. (Motivational intensity)

\begin{tabular}{|l|l|l|l|l|l|l|}
\hline 1 & 2 & 3 & 4 & 5 & 6 & 7 \\
\hline
\end{tabular}

26) I felt good when doing the picture description task. (Task motivation)

\begin{tabular}{|l|l|l|l|l|l|l|}
\hline 1 & 2 & 3 & 4 & 5 & 6 & 7 \\
\hline
\end{tabular}

27) I haven't any great wish to learn more French than I already know. (Motivational intensity)

\begin{tabular}{|c|l|l|l|l|l|l|}
\hline 1 & 2 & 3 & 4 & 5 & 6 & 7 \\
\hline
\end{tabular}

28) I think that the picture description task helped me learn the French structures presented in the task. (Metacognition)

\begin{tabular}{|c|c|c|c|c|c|c|}
\hline 1 & 2 & 3 & 4 & 5 & 6 & 7 \\
\hline
\end{tabular}

29) I often think about how I can learn French better. (Motivational intensity)

\begin{tabular}{|c|c|c|c|c|c|c|}
\hline 1 & 2 & 3 & 4 & 5 & 6 & 7 \\
\hline
\end{tabular}

30) Studying languages is not a pleasant experience. (Intrinsic motivation)

\begin{tabular}{|l|l|l|l|l|l|l|}
\hline 1 & 2 & 3 & 4 & 5 & 6 & 7 \\
\hline
\end{tabular}

31) I could do my language proficiency justice when doing the picture description task.

(Metacognition)

\begin{tabular}{|c|l|l|l|l|l|l|}
\hline 1 & 2 & 3 & 4 & 5 & 6 & 7 \\
\hline
\end{tabular}

32) I always look forward to French classes. (Intrinsic motivation)

\begin{tabular}{|l|l|l|l|l|l|l|}
\hline 1 & 2 & 3 & 4 & 5 & 6 & 7 \\
\hline
\end{tabular}

33) I find the study of French very boring. (Intrinsic motivation)

\begin{tabular}{|l|l|l|l|l|l|l|}
\hline 1 & 2 & 3 & 4 & 5 & 6 & 7 \\
\hline
\end{tabular}


34) I want to learn an appropriate and rich vocabulary in French. (Learning goal)

\begin{tabular}{|l|l|l|l|l|l|l|}
\hline 1 & 2 & 3 & 4 & 5 & 6 & 7 \\
\hline
\end{tabular}

35) I didn't find the picture description task interesting. (Task motivation)

\begin{tabular}{|l|l|l|l|l|l|l|}
\hline 1 & 2 & 3 & 4 & 5 & 6 & 7 \\
\hline
\end{tabular}

36) When I am in French class, I do not volunteer answers. (Motivational intensity)

\begin{tabular}{|l|l|l|l|l|l|l|}
\hline 1 & 2 & 3 & 4 & 5 & 6 & 7 \\
\hline
\end{tabular}

37) I want to acquire an accurate and clear pronunciation in French. (Learning goal)

\begin{tabular}{|c|c|c|c|c|c|c|}
\hline 1 & 2 & 3 & 4 & 5 & 6 & 7 \\
\hline
\end{tabular}

38) I keep up with French by working on it almost every day. (Motivational intensity)

\begin{tabular}{|c|c|c|c|c|c|c|}
\hline 1 & 2 & 3 & 4 & 5 & 6 & 7 \\
\hline
\end{tabular}

39) I didn't enjoy the picture description task. (Task motivation)

\begin{tabular}{|c|c|c|c|c|c|c|}
\hline 1 & 2 & 3 & 4 & 5 & 6 & 7 \\
\hline
\end{tabular}

40) I want to develop an accurate and complex grammatical knowledge in French.

(Learning goal)

\begin{tabular}{|l|l|l|l|l|l|l|}
\hline 1 & 2 & 3 & 4 & 5 & 6 & 7 \\
\hline
\end{tabular}

41) I don't think that this picture description task helped me learn French.

(Metacognition)

\begin{tabular}{|c|c|c|c|c|c|c|}
\hline 1 & 2 & 3 & 4 & 5 & 6 & 7 \\
\hline
\end{tabular}

42) I have little interest in languages. (Intrinsic motivation)

\begin{tabular}{|l|l|l|l|l|l|l|}
\hline 1 & 2 & 3 & 4 & 5 & 6 & 7 \\
\hline
\end{tabular}

43) I think improving my French grammatical knowledge is a waste of time. (Learning goal)

\begin{tabular}{|c|l|l|l|l|l|l|}
\hline 1 & 2 & 3 & 4 & 5 & 6 & 7 \\
\hline
\end{tabular}

44) I plan to continue studying French for as long as possible. (Motivational intensity)

\begin{tabular}{|l|l|l|l|l|l|l|}
\hline 1 & 2 & 3 & 4 & 5 & 6 & 7 \\
\hline
\end{tabular}

45) I think the French structures presented in the picture description task are hard to learn.

(Metacognition)

\begin{tabular}{|c|c|c|c|c|c|c|}
\hline 1 & 2 & 3 & 4 & 5 & 6 & 7 \\
\hline
\end{tabular}

46) I think that this picture description task helped me work towards my language learning goal(s). (Metacognition)

\begin{tabular}{|c|c|c|c|c|c|c|}
\hline 1 & 2 & 3 & 4 & 5 & 6 & 7 \\
\hline
\end{tabular}

47) I think that the picture description task challenged my French skills nicely.

\section{(Metacognition)}

\begin{tabular}{|c|l|l|l|l|l|l|}
\hline 1 & 2 & 3 & 4 & 5 & 6 & 7 \\
\hline
\end{tabular}


48) I always look forward to interacting with a French native speaker. (Intrinsic motivation)

\begin{tabular}{|l|l|l|l|l|l|l|}
\hline 1 & 2 & 3 & 4 & 5 & 6 & 7 \\
\hline
\end{tabular}

Appendix D. Loadings of each motivation item on each PC.

Table 1. Motivation items and their loadings on PC1.

\begin{tabular}{|c|c|c|}
\hline $\begin{array}{l}\text { Survey } \\
\text { Section }\end{array}$ & Survey Items & $\begin{array}{c}\text { PC1 } \\
\text { Loadings }\end{array}$ \\
\hline MI & I am working hard at learning French. & .68 \\
\hline PV & Learning French is one of the most important aspects of my life. & .63 \\
\hline GLL & $\begin{array}{l}\text { I want to develop an accurate and complex grammatical knowledge } \\
\text { of French. }\end{array}$ & .63 \\
\hline MI & $\begin{array}{l}\text { I often think about the words and ideas that I learnt in my French } \\
\text { classes. }\end{array}$ & .62 \\
\hline MI & I often think about how I can learn French better. & .59 \\
\hline MI & I keep up with French by working on it almost every day. & .59 \\
\hline $\mathrm{IM}$ & I have little interest in languages. * & .59 \\
\hline PV & Being able to speak French is something I personally value. & .57 \\
\hline $\mathrm{IM}$ & I always look forward to speaking French. & .56 \\
\hline MI & I plan to continue studying French for as long as possible. & .56 \\
\hline $\mathrm{IM}$ & Studying languages is not a pleasant experience. $*$ & .56 \\
\hline IM & I always look forward to French classes. & .53 \\
\hline MI & $\begin{array}{l}\text { If my teacher were to give an optional assignment, I would } \\
\text { certainly volunteer to do it. }\end{array}$ & .50 \\
\hline $\mathrm{IM}$ & I always look forward to interacting with a French native speaker. & .49 \\
\hline $\mathrm{IM}$ & I find the study of French very boring. * & .47 \\
\hline IM & I enjoy the experience of surpassing myself when speaking French. & .46 \\
\hline EM & $\begin{array}{l}\text { I want to spend a period of time in/ emigrate to a French-speaking } \\
\text { country. }\end{array}$ & .46 \\
\hline
\end{tabular}

Codes for survey sections: $M I=$ Motivation Intensity, $P V=$ Personal Value, $G L L=$ GrammarLearning Goal, IM= Intrinsic Motivation, EM= External Motivation. $P C 1=$ French Learning Motivation.

*these items were reverse-coded. 
Table 2. Motivation items and their loadings on PC2.

\begin{tabular}{|c|c|c|}
\hline $\begin{array}{l}\text { Survey } \\
\text { Section }\end{array}$ & Survey Items & $\begin{array}{l}\text { PC2 } \\
\text { Loadings }\end{array}$ \\
\hline TM & I did not enjoy the picture description task.* & .72 \\
\hline M & $\begin{array}{l}\text { I think that this picture description task helped me work towards my } \\
\text { language learning goal(s). }\end{array}$ & .71 \\
\hline TM & $\begin{array}{l}\text { If I had the opportunity, I would spend more time doing tasks like } \\
\text { the picture description task. }\end{array}$ & .66 \\
\hline $\mathrm{TM}$ & I did not find the picture description task interesting. * & .60 \\
\hline M & $\begin{array}{l}\text { I think that the picture description task challenged my French skills } \\
\text { nicely. }\end{array}$ & .60 \\
\hline M & $\begin{array}{l}\text { I do not think that this picture description task helped me learn } \\
\text { French.* }\end{array}$ & .59 \\
\hline $\mathrm{TM}$ & I did not put a lot of effort into doing the picture description task. * & .55 \\
\hline M & $\begin{array}{l}\text { I think that the picture description task helped me learn the French } \\
\text { structures presented in the task. }\end{array}$ & .55 \\
\hline EM & $\begin{array}{l}\text { I am learning French because without passing the French course, I } \\
\text { cannot get my degree. }\end{array}$ & -.52 \\
\hline
\end{tabular}

Codes for survey sections: EM= External Motivation, TM= Task Motivation,

M=Metacognition. $P C 2=$ Task-Specific Motivation. *these items were reverse-coded . 